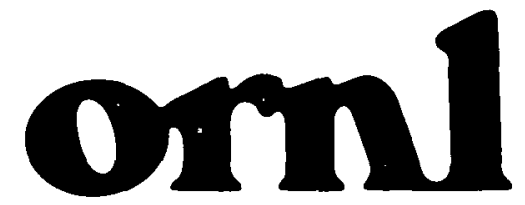

\section{OAK RIDGE NATIONAL LABORATORY}

LOCKHEED MATTIN /

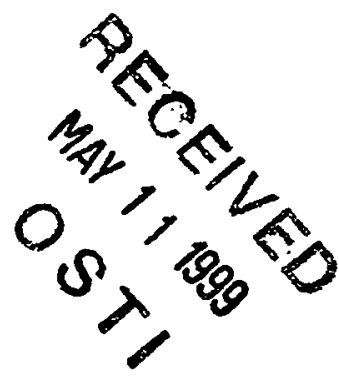

ORNL/TM-13725

\title{
Cementitious Stabilization of Mixed Wastes With High Salt Loadings
}

R. D. Spence

M. W. Burgess

V. V. Fedorov

D. J. Downing 
This report has been reproduced from the best available copy.

Reports are available to the public from the following source.

National Technical Information Service

5285 Port Royal Road

Springfield, VA 22161

Telephone 703-605-6000 (1-800-553-6847)

TDD 703-487-4639

Fax 703-605-6900

E-mail orders@ ntis.fedworld.gov

Web site http://www.ntis.gov/ordering.htm

Reports are available to U.S. Department of Energy (DOE) employees, DOE contractors, Energy Technology Data Exchange (ETDE) representatives, and International Nuclear Information System (INIS) representatives from the following source.

Office of Scientific and Technical Information

P.O. Box 62

Oak Ridge, TN 37831

Telephone 423-576-8401

Fax 423-576-5728

E-mail reports@adonis.osti.gov

Web site http://www.osti.gov/products/sources.html

Reports produced after January 1, 1996, are generally available via the DOE Information Bridge.

Web site http://www.doe.gov/bridge 


\section{DISCLAIMER}

This report was prepared as an account of work sponsored by an agency of the United States Government. Neither the United States Government nor any agency thereof, nor any of their employees, make any warranty, express or implied, or assumes any legal liability or responsibility for the accuracy, completeness, or usefulness of any information, apparatus, product, or process disclosed, or represents that its use would not infringe privately owned rights. Reference herein to any specific commercial product, process, or service by trade name, trademark, manufacturer, or otherwise does not necessarily constitute or imply its endorsement, recommendation, or favoring by the United States Government or any agency thereof. The views and opinions of authors expressed herein do not necessarily state or reflect those of the United States Government or any agency thereof. 


\section{DISCLAIMER}

Portions of this document may be illegible in electronic image products. Images are produced from the best available original document. 
ORNL/TM-13725

Chemical Technology Division

\section{CEMENTITIOUS STABLIZATION OF MIXED WASTES WITH HIGH SALT LOADINGS}

R. D. Spence, M. W. Burgess, V. V. Fedorov, ${ }^{*}$ and D. J. Downing*

*Formerly affiliated with the Statistics Group, Computer Science and Mathematics Division.

April 1999

Prepared by

OAK RIDGE NATIONAL LABORATORY

Oak Ridge, Tennessee 37831-6202

managed by

LOCKHEED MARTIN ENERGY RESEARCH CORP.

for the

U.S. DEPARTMENT OF ENERGY

under contract DE-AC05-96OR22464 


\section{CONTENTS}

LIST OF TABLES $\ldots \ldots \ldots \ldots \ldots \ldots \ldots \ldots \ldots \ldots \ldots \ldots \ldots \ldots \ldots \ldots \ldots$

LIST OF FIGURES $\ldots \ldots \ldots \ldots \ldots \ldots \ldots \ldots \ldots \ldots \ldots \ldots \ldots \ldots \ldots \ldots \ldots$

ABSTRACT $\quad \ldots \ldots \ldots \ldots \ldots \ldots \ldots \ldots \ldots \ldots \ldots \ldots \ldots \ldots \ldots \ldots \ldots \ldots \ldots \ldots \ldots$

1. INTRODUCTION $\ldots \ldots \ldots \ldots \ldots \ldots \ldots \ldots \ldots \ldots \ldots \ldots \ldots \ldots \ldots \ldots$

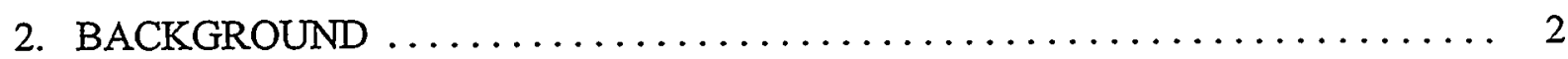

2.1 STATEMENT OF THE NEED FOR MIXED-WASTE TREATMENT . . . . . 2

2.2 TECHNOLOGY CONCEPT AND FUNCTION $\ldots \ldots \ldots \ldots \ldots \ldots \ldots \ldots \ldots$

2.3 SHORT SURVEY OF CURRENT STATUS OR STAGE OF

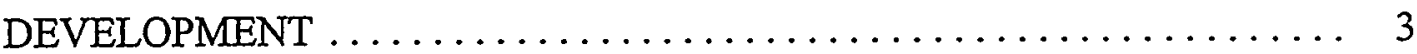

2.4 NEEDED TECHNOLOGY IMPROVEMENTS $\ldots \ldots \ldots \ldots \ldots \ldots \ldots \ldots \ldots$

3. INITIAL STATISTICAL DESIGN $\ldots \ldots \ldots \ldots \ldots \ldots \ldots \ldots \ldots \ldots \ldots \ldots$

3.1 BASIS FOR STATISTICAL DESIGN OF EXPERIMENTS $\ldots \ldots \ldots \ldots \ldots .6$

3.2 CONSTRUCTION OF D-OPTIMAL DESIGN FOR INITIAL DESIGN $\ldots \ldots \ldots 10$

3.3 SLUDGE USED IN LABORATORY TESTING $\ldots \ldots \ldots \ldots \ldots \ldots \ldots \ldots 11$

3.4 RESULTS FROM THE INITIAL DESIGN . . . . . . . . . . . . . 13

3.5 PRELIMINARY COMPRESSIVE-STRENGTH MODEL FROM THE

INTTIAL DESIGN $\ldots \ldots \ldots \ldots \ldots \ldots \ldots \ldots \ldots \ldots \ldots \ldots \ldots \ldots \ldots$

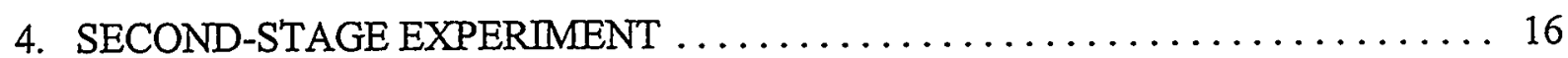

4.1 CONSTRUCTION OF D-OPTIMAL DESIGN FOR THE SECOND STAGE . 16

4.2 RESULTS . . . . . . . . . . . . . . . . 17

4.3 REGRESSION ANALYSIS OF THE RESULTS OF THE INITIAL AND

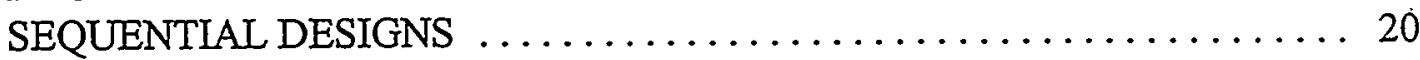

5. TESTS USING STANDARD MWFA SURROGATE SLUDGES $\ldots \ldots \ldots \ldots$

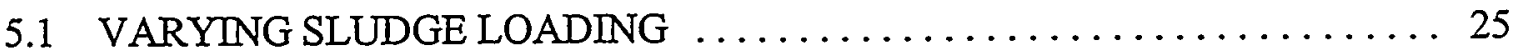

5.2 VARYING THE CHLORIDE AND SULFATE LOADINGS . . . . . . . . 27

6. SUMMARY AND CONCLUSIONS $\ldots \ldots \ldots \ldots \ldots \ldots \ldots \ldots \ldots \ldots \ldots$

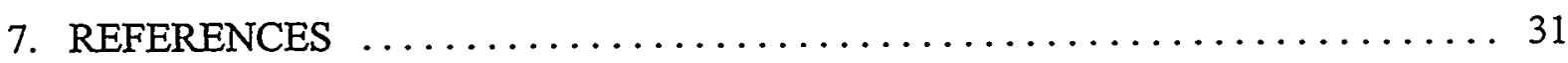

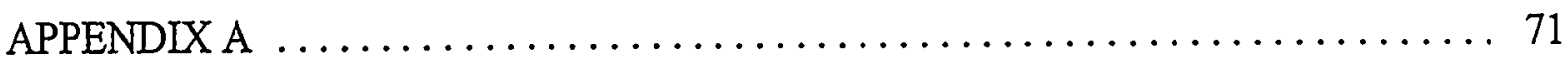

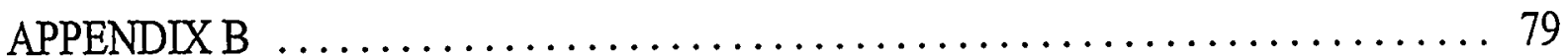

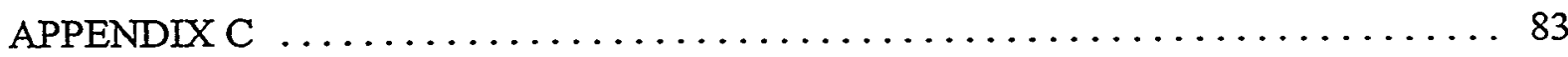




\section{LIST OF TABLES}

1 Composition of standard MWFA surrogate sludges $\ldots \ldots \ldots \ldots \ldots \ldots \ldots 37$

2 Initial statistical design used in laboratory testing after broadening constraints to incorporate MWFA surrogate and using $<70 \%$ nitrate $\ldots \ldots \ldots \ldots \ldots$

3 Total concentrations measured in the ECM sludge samples ............ 40

4 Average, standard deviation, and percentage RSD of the significant total concentrations measured in the ECM sludge samples and TCLP extract concentrations of bucket composite samples . . . . . . . . . . . . 41

5 Grout compositions for the initial design ..................... 42

6 Additional data for the wet sludge makeup for the initial design $\ldots \ldots \ldots . \ldots 44$

$7 \quad$ Performance test results for the initial design $\ldots \ldots \ldots \ldots \ldots \ldots \ldots \ldots \ldots$

8 TCLP performance of the initial-design grouts $\ldots \ldots \ldots \ldots \ldots \ldots \ldots \ldots, 48$

9 Components of the sequential statistical design $\ldots \ldots \ldots \ldots \ldots \ldots \ldots . \ldots$

10 Composition of grouts for the sequential design $\ldots \ldots \ldots \ldots \ldots \ldots \ldots \ldots . \ldots \ldots$

11 Additional data for the wet-sludge makeup for the sequential-design grouts . . .. 52

12 Performance test results for the sequential-design grouts $\ldots \ldots \ldots \ldots \ldots \ldots 5$

13 TCLP performance of the sequential-design grouts $\ldots \ldots \ldots \ldots \ldots \ldots \ldots . \ldots 4$

14 Compositions of grouts made from the standard MWFA surrogate sludges using

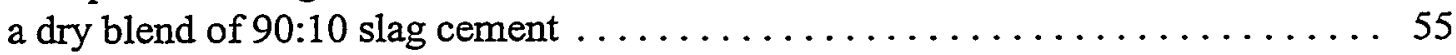

15 Performance testing results for the standard MWFA surrogate sludges $\ldots \ldots \ldots 56$

16 TCLP performance of the standard MWFA surrogate sludges $\ldots \ldots \ldots \ldots \ldots 7$

17 Standard MWFA surrogate sludge grouts put on the same compositional basis as that listed for the statistical-design grouts $\ldots \ldots \ldots \ldots \ldots \ldots \ldots \ldots \ldots \ldots, 58$ 


\section{TABLES (continued)}

18 Additional data for the wet-sludge makeup for the grouts made from the

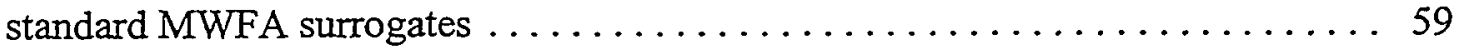

19 Final compositions of the grouts with high chloride and sulfate loadings $\ldots \ldots 60$

20 Additional data for the wet-sludge makeup for the grouts prepared with highchloride and high-sulfate loadings $\ldots \ldots \ldots \ldots \ldots \ldots \ldots \ldots \ldots \ldots \ldots \ldots \ldots$

21 Performance testing results testing high-chloride and high-sulfate loadings $\ldots \ldots 62$

22 TCLP performance test results for high-chloride and high-sulfate loadings . . . . 63 


\section{LIST OF FIGURES}

1 Wet ECM sludge and wet sludge made from MWFA components with the typical grouts prepared from these sludges $\ldots \ldots \ldots \ldots \ldots \ldots \ldots \ldots \ldots 64$

2 Contour lines of 500-psi compressive strength for preliminary model of initial

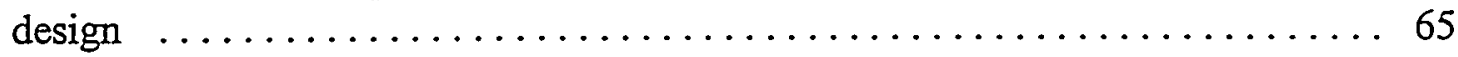

3 Fraction of chromium extracted in TCLP test as a function of the slag content

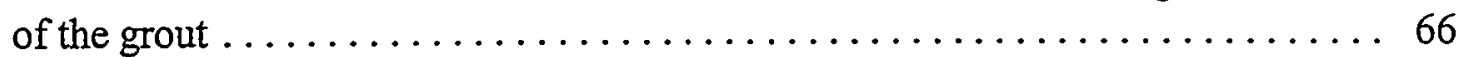

4 Fraction of cadmium extracted during TCLP analysis as a function of the wet-sludge content of the grout $\ldots \ldots \ldots \ldots \ldots \ldots \ldots \ldots \ldots \ldots \ldots \ldots \ldots \ldots \ldots \ldots \ldots$

5 Contour plots of average unconfined compressive strength for the recommended model from the initial design $\left(x_{3}=0.21, x_{5}=0, x_{6}=0, x_{7}=0.4, x_{8}=-1\right) \ldots \ldots 68$

6 Contour plot of the percentage of chromium extracted during TCLP for the recommended model from the initial design . ...................... 69

7 MWFA surrogate sludges with the standard water content from Table 2 and with the minimum amount of water added to make a wet, mixable paste . . . . . . 70 


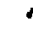




\begin{abstract}
Salt loadings approaching $50 \mathrm{wt} \%$ were tolerated in cementitious waste forms that still met leach and strength criteria, addressing a Technology Deficiency of low salt loadings previously identified by the Mixed Waste Focus Area. A statistical design quantified the effect of different stabilizing ingredients and salt loading on performance at lower loadings, allowing selection of the more effective ingredients for studying the higher salt loadings. In general, the final waste form needed to consist of $25 \mathrm{wt} \%$ of the dry stabilizing ingredients to meet the criteria used and $25 \mathrm{wt} \%$ water to form a workable paste, leaving $50 \mathrm{wt} \%$ for waste solids. The salt loading depends on the salt content of the waste solids but could be as high as $50 \mathrm{wt} \%$ if all the waste solids are salt.
\end{abstract}




\section{INTRODUCTION}

This project addresses Technology Deficiency 7, Salt Stabilization, identified by the Mixed Waste Focus Area (MWFA). The Technology Development Requirements Document (TDRD) indicates that current stabilization practices are limited to salt loadings of $<10 \mathrm{wt} \%$. The proposed technology expands the salt loadings for cementitious, or grout, waste forms well past $10 \mathrm{wt} \%$ salt loadings. Currently, sludge solid loadings of up to $30 \mathrm{wt} \%$ are being routinely tested in the Materials Technology Group in the Engineering Development Section of the Chemical Technology Division (CTD) at Oak Ridge National Laboratory (ORNL). The effect of salt loading on cementitious waste form performance was explored with salt loadings approaching $50 \mathrm{wt} \%$. A study was conducted using a sequence of two multidimensional statistical experimental designs, followed by a simpler coordinate-wise design (varying one component while holding the other components constant relative to each other) in a relatively small region defined from the previous stages. The information gained from the first set of measurements was used to narrow the focus to the better formulations at higher salt loadings in the subsequent designs, more fully exploring the limits of salt loading. The data were used to generate empirical surface response models for predicting the properties as a function of eight variables-three salts (chloride, sulfate, and nitrate), four cementitious additives (slag, cement, fly ash, and clay), and water-with possible filtering out of statistically insignificant ones. The properties measured and reported in this document are grout density, ratio of grout volume to sludge volume, free-standing liquid, unconfined compressive strength, and Toxic Chemical Leaching Procedure (TCLP) performance. Unconfined compressive strength and percentage of chromium extracted during TCLP testing were modeled.

The models that were generated for the sludges used in these tests may not necessarily be quantitatively extrapolated accurately to other wastes. However, they will provide the general trend of grout strength and leach resistance with salt loading, indicating which ingredients are important to performance and giving a general idea of salt loading limit. With the demonstration that much higher salt loadings can be tolerated, the mature technology of cementitious waste forms can be applied with salt loadings up to $50 \mathrm{wt} \%$ and, consequently, a much lower waste 
volume increase (about $10 \%$ or less). For instance, a small waste loading of $<10 \mathrm{wt} \%$ may cause a significant increase in volume (tenfold), severely limiting the attractiveness of this widely used technology. The results of the salt loading experiments and the efforts to develop empirical models from the data are reported in the sections that follow.

\section{BACKGROUND}

\subsection{STATEMENT OF THE NEED FOR MIXED-WASTE TREATMENT}

This project addresses the Technology Deficiency 7, Salt Stabilization, discussed in the MWFA's "Technology Development Requirements Document, Salt Stabilization (Deficiency 7)," July 30, 1996. As described in this TDRD, the current standard practice for stabilization of wastes containing salts and residues is to mix them with portland cement at low salt loadings or to mix them with a proprietary cement derivative, which includes additives to enhance the immobilization of specific metals or problematic anions. Stabilization of wastes containing significant concentrations of chloride, nitrate, or sulfate salts may require the addition of significant amounts of additives, resulting in a severalfold volume increase, to achieve a wellcured product that meets disposal requirements for free liquids, compressive strength, and leachability. Improved stabilization methods would accept higher salt loading and treat wastes with small quantities of liquids, while meeting waste form disposal criteria.

\subsection{TECHNOLOGY CONCEPT AND FUNCTION}

The proposed technology is to modify the portland cement formulations by substituting another binder for the portland cement and by making the basic waste form matrix more plastic (and, thus, more forgiving of later mineral expansions, which can result from high salt loadings). Because the grout properties depend on a large number of factors (eight in this study), only a statistical design of experiments can make it affordable to construct the corresponding empirical models. For instance, to fit a simple linear model that contains eight input variables, the 
traditional approach (observations are made on a grid $\mathrm{k}_{1} \times \mathrm{k}_{2} \times \ldots \times \mathrm{k}_{8}$ ) even in the most parsimonious case, $k_{1}=k_{2}=\ldots k_{8}=2$, needs $2^{8}$ observations. The situation is worsened by the presence of various constraints that are imposed on varying factors. Experimental design theory leads to designs for linear models which have the number of observations on the order of "the number of unknown parameters" times "the number of repetitions."

A troublesome issue may be the long-term destructive expansion of minerals inside the grout after the grout hardens. Such destructive expansion has been observed by the late formation of ettringite (calcium sulfoaluminate), calcium chloroaluminate, and darapskite (sodium nitrate sulfate). For this reason, observations of expansion over long periods (1-2 years beyond the first 12 months) were originally planned for this work but were abandoned when budget cuts prohibited any work beyond the first 12 months.

The proposed technology is a modification of the standard portland cement formulations by substituting another binder-ground granulated blast-furnace slag-for the portland cement and modifying the basic cementitious matrix into a more plastic matrix using clay(s). Substitution of a slower-set binder will make the formulation more tolerant of higher salt loadings, and the plastic matrix will make the formulation more tolerant of the later formation of expansive phases. The imposition of the recommended criteria of the NRC topical position paper $^{1}$ with an average compressive strength $>500$ psi for cementitious waste forms made the objective of a plastic matrix with high-clay contents moot, because such waste forms will deform or flow under compression, by definition.

\subsection{SHORT SURVEY OF CURRENT STATUS OR STAGE OF DEVELOPMENT}

The Materials Technology Group of the CTD, at ORNL, has continued, and is continuing, to develop cementitious formulations for salty supernates and sludges (Hydrofracture grouts for the Gunite tank sludges and supernates, Hanford tank supernate grouts, and Melton Valley Storage Tank supernate and sludge grouts). ${ }^{2-16}$ These supernates typically have had a salt concentration of a few molar ( $3-5 \mathrm{M}$ ), and the grouts have typically consisted of mix ratios of about $8 \mathrm{lb}$ of dry blend per gallon of supernate, resulting in salt loadings of about $>9 \mathrm{wt} \%$ in the 
final waste form. Sludges typically resulted in higher waste solids loadings of $20-30 \mathrm{wt} \%$ (mainly oxides, hydroxides, and carbonates), depending on the water content of the sludge.

In addition to the work conducted at ORNL over the past three decades, several other organizations have studied the solidification of salty sludges and solutions, including the Savannah River National Laboratory ${ }^{17-23}$, the Rocky Flats Plant, ${ }^{24}$ Brookhaven National Laboratory, ${ }^{25}$ Argonne National Laboratory, ${ }^{26}$ West Valley Nuclear Services, ${ }^{27}$ Pacific Northwest National Laboratory, ${ }^{28}$ France, ${ }^{29-33}$ and Argentina. ${ }^{34}$

After studying spray-dried nitrate salt solidification by portland cement, gypsum cement, and silicate cement, Petersen et al. ${ }^{24}$ recommended portland cement with a $55 \mathrm{wt} \%$ waste loading of spray-dried nitrate salt. Rocky Flats did observe expansion from darapskite formation in containers of spray-dried salt solidified in grout that was allowed to sit outside in the weather for several months. The saltstone developed at Savannah River solidifies a salt solution containing about $32 \mathrm{wt} \%$ sodium salts in a cement-based waste form at a solution loading of up to $48.5 \mathrm{wt} \%$, for a salt loading of about $15 \mathrm{wt} \% .^{18}$ Zhou and Colombo ${ }^{25}$ studied the solidification of boric acid; ion-exchange resins; incinerator ash; and sodium sulfate, which is the salt of interest to MWFA. It was found that, although waste forms could be prepared with sodium sulfate loadings up to $40 \mathrm{wt} \%$, a $7 \mathrm{wt} \%$ sodium sulfate loading in a lime-cement mix (masonry cement) underwent catastrophic failure during water immersion, while a $9 \mathrm{wt} \%$ loading in Type I portland cement suffered little damage. Immersion in water in the presence of free lime and sodium sulfate apparently led to the formation of expansive minerals, (e.g., ettringite).

Fischer and Johnson ${ }^{26}$ studied the effects of chloride salts (calcium, sodium, and lithium) on mortar properties, including compressive strength. They found that these salts did weaken the mortar, especially the early strength, with a chloride salt loading of $18 \mathrm{wt} \%$, resulting in compressive strengths of 870 and 2118 psi at 28 and 56 days, respectively. These strengths are well above the NRC-recommended average compressive strength of $500 \mathrm{psi}$ (the sample attained 500 psi in about 7 days). Note that the authors were using cement-fly ash mortars, which set faster than high-slag grouts, and the salt contained a high concentration of calcium chloride, a known set accelerator, implying that the slag-cement grouts and salts without calcium chloride in the present study will set and develop early strength at significantly slower times than those 
observed in the previous study (set times of a few days for the present study as compared with $7 \mathrm{~h}$ or less in the prior study).

McVay et al. ${ }^{27}$ solidified a solution containing $39 \mathrm{wt} \%$ salts (mainly sodium salts) in Type I portland cement at a mix ratio of $11.2 \mathrm{lb}$ of cement per gallon of solution. Assuming a solution density of about $10 \mathrm{lb} / \mathrm{gal}$, this implies a salt loading of about $18 \mathrm{wt} \%$ with a compressive strength of about 1000 psi for several drums of solidified solution.

Lokken et al. ${ }^{28}$ solidified a salt solution containing approximately $32 \mathrm{wt} \%$ salts and precipitated solids in a high-slag grout at a mix ratio of $9 \mathrm{lb} / g a l$. The density of the salt solution was about $10 \mathrm{lb} / \mathrm{gal}$, which implies that the salt and precipitated solids loading was about $17 \mathrm{wt} \%$.

Bouniol ${ }^{30}$ and Atabek et al..$^{32}$ studied the solidification of solutions of salts (nitrate, sulfate, and/or halide) at concentrations of about $1 \mathrm{lb} /$ gal. Kertesz et al. ${ }^{33}$ studied the solidification of a phosphate waste in various binders, including cement at a waste/cement ratio of 0.30. In a collaborative effort between the Commissariat a l'energie Atomique (CEA) and ORNL, the solidification of a high-salt concentrate $(3.8 \mathrm{lb} / \mathrm{gal})$ was studied.

\subsection{NEEDED TECHNOLOGY IMPROVEMENTS}

Improved stabilization methods would accept higher salt loadings (greater than $10 \mathrm{wt} \%$ weight salt) and treat wastes without drying, while meeting waste form disposal criteria. Increasing the salt loading of waste forms will directly impact the final waste form volume and the cost of disposal. Increasing the salt loading from $<10$ to $30 \mathrm{wt} \%$ (or more) will decrease the final waste volume by more than a factor of 3 . 


\section{INITIAL STATISTICAL DESIGN}

\subsection{BASIS FOR STATISTICAL DESIGN OF EXPERIMENTS}

In this study we have a twofold purpose in mind: (1) To quantify the relationship between the values of the measurable grout characteristics (response variables) and those of a set of experimental factors presumed to affect the responses and (2) to find the values of the factors that produce the best value(s) of the grout characteristics. The corresponding area of statistics (i.e., design of experiments) allows a practitioner to select a parsimonious, but informative, set of observations. Basic information on this subject has been published by Box and Draper. ${ }^{35}$ The essential components of the approach are the formulation of a possible relationship between response(s) and input variables, selection of the set of input variables that at least theoretically can affect a response, and determination of the area in which those variables can be varied (controlled).

In this study we decided to use one of the simplest response models,

$$
\gamma(\mathrm{x})=\theta_{\mathrm{o}}+\theta_{1} \mathrm{x}_{1}+\ldots+\theta_{\mathrm{m}} \mathrm{x}_{\mathrm{m}}+\varepsilon(\mathrm{x})
$$

This is the so-called linear regression, and frequently it is considered as the first-order Taylor approximation of

$$
\theta_{0}=f(x, \bar{y})+\varepsilon(x),
$$

with

$$
\theta_{o}=\eta(x, \bar{\gamma}), \theta_{\alpha}=\mathrm{df}(\mathrm{x}, \bar{\gamma}) /\left.\mathrm{d} \gamma_{\mathrm{d}}\right|_{\gamma=\bar{\gamma}},
$$

where $\eta(x, \gamma)$ is an actual response function, which is usually unknown, and

$$
\gamma=\left(\gamma_{1}, \ldots, \gamma_{\mathrm{m}}\right)^{\mathrm{T}},
$$

where $\gamma$ is the best estimation of true values of $\gamma$. The term $\varepsilon(x)$ comprises various 
observational errors. Usually it is reasonable to assume that $\varepsilon(\mathrm{x})$ has zero mean, uncorrelated for different observations, and its variance is approximately the same for different $x$ values.

The list of input variables, in terms of masses, includes the following:

$$
\begin{array}{llll}
\mathrm{x}_{1}=\text { cement } & \mathrm{x}_{2}=\text { slag } & \mathrm{x}_{3}=\text { clay } & \mathrm{x}_{4}=\text { fly ash } \\
\mathrm{x}_{5}=\text { chloride } & \mathrm{x}_{6}=\text { sulfate } & \mathrm{x}_{7}=\text { nitrate } & \mathrm{x}_{8}=\text { water }
\end{array}
$$

In general, model (1) together with linear terms may include more complicated ones such as interactions $x_{\alpha} x_{\beta}$, quadratic terms $x^{2}$, etc. Therefore, instead of Eq. (1), we can use, in general,

$$
y_{i}=\eta\left(X_{i}, \theta\right)+\varepsilon_{i} .
$$

The determination of the design region $\mathrm{X}$, that is, the area or set of points from which the values of the input variables can be selected, is one of the major stages in experimental design and usually is a compromise between a few contradicting demands. For instance, from the statistical point of view, it is important to extend the $\mathrm{X}$ as much as possible. However, model (1) may be valid only in relatively small areas. Some combinations of input variables may be considered as useless or unrealistic from the practical standpoint. For instance, we cannot obtain any reasonable grout(s) if the mixture does not include cement or water.

At the first stage of the study, the design region $\mathrm{X}$ was defined as follows:

$\mathrm{x}_{5}+\mathrm{x}_{6}+\mathrm{x}_{7}+$ solid waste $=1$ (one unit of weight; it can be $1 \mathrm{lb}$ ),

$x_{5}+x_{6}+x_{7} \leq 0.5$

$\mathrm{x}_{5}+\mathrm{x}_{6}+\mathrm{x}_{7} \geq 0.2$

$x_{2} \leq 2.7, x_{3} \leq 0.4, x_{4} \leq 0.9$,

$x_{1} \geq 0.1 x_{2}$,

$0.7 \leq x_{1}+x_{2} \leq 2.7$. 
The term solid waste results from the use of an actual mixed-waste sludge sample to provide a background matrix to test varying amounts of the salts of chloride, sulfate, and nitrate. By constraining these salt solids-salts plus solid waste--to a unit weight, the masses of the stabilizing agents are fixed relative to this unit mass of salt solids (e.g., mass cement per unit mass of salt solids), and the salt variables are the mass fractions of the individual salts in the unit weight of waste. Water is used at two qualitative levels: (1) minimum water for a mixable wet paste and (2) slightly more water for easier processibility of the grout. These water contents may only be determined during mixing of each grout and are reported in Table 1 as +1 and -1 , respectively.

As soon as the response function or model and the design region $\mathrm{X}$ are defined, we have to select an optimality criterion. At the first experimental stage, we probably want some assurance that all parameters $\theta_{0}, \ldots, \theta_{\mathrm{m}}$ are well estimated. In this case, it is usually recommended to select a design (i.e., a set of points in $\mathrm{X}$ where measurements must be done) that minimizes the generalized variance of the parameter estimators $\theta$. Let

$$
\left.\mathrm{D}_{\mathrm{a} \beta}=\operatorname{Cov}\left(\theta_{\alpha}, \theta_{\beta}\right)=E\left[\theta_{\alpha}-\theta_{\alpha \text { true }}\right)\left(\theta_{\beta}-\theta_{\beta \text { true }}\right)\right],
$$

where $E$ refers to the operation of expectation, the subscript "true" indicates the true value of the unknown parameter, and $\operatorname{Cov}\left(\theta_{\alpha}, \theta_{\beta}\right)$ denotes the covariance of estimators $\theta_{\alpha}$ and $\theta_{\beta}$, if $\alpha=\beta$, and the variance of estimator $\theta_{\alpha}$, if $\alpha=\beta$, i.e., $\operatorname{Var} \theta_{\alpha}=\operatorname{Cov}\left(\theta_{\alpha}, \theta_{\alpha}\right.$.). We assume that $\theta_{\alpha}, \alpha=0,1 \ldots$, are the least-square estimators; that is, they correspond to

$$
\min _{\theta} \sum_{\mathrm{i}=1}^{\mathrm{n}}\left(\mathrm{y}_{\mathrm{i}}-\sum_{\alpha=0}^{\mathrm{m}} \theta_{\alpha} \mathrm{x}_{\alpha} \mathrm{i}\right)^{2},
$$

where $i$ is the number of an observation, $x_{0 \mathrm{i}} \equiv 1$. It is known that the vector $\theta$ is the best linear unbiased estimator (i.e., $\mathrm{E}(\theta)=\theta_{\text {true }}$ ) and has the least covariance matrix (see details, as described by Fedorov and $\mathrm{Hackl}^{36}$ ). The symmetrical matrix is called the covariance matrix, and its 


$$
\mathrm{D}\left(\begin{array}{ccc}
\mathrm{D}_{11} & \ldots & \mathrm{D}_{1 \mathrm{~m}} \\
\ldots & \ldots & \ldots \\
\mathrm{D}_{\mathrm{m} 1} & \ldots & \mathrm{D}_{\mathrm{mm}}
\end{array}\right)
$$

determinant $|D|$ is called the generalized variance. If the observational errors are normally distributed, then $-\ln |D|$ is the Shennon information gained from an experiment. If we describe a design as a collection of points

$$
\mathrm{x}_{\mathrm{i}}=\left(\mathrm{x}_{1 \mathrm{i}}, \ldots, \mathrm{x}_{\mathrm{mi}}\right), \mathrm{i}=1, \ldots, \mathrm{n},
$$

then an optimal design consists of points that correspond to

$$
\underset{x_{1} \ldots, x_{n}}{\min D}
$$

and it is referred to as a D-optimal design. It is known that for the homogeneous observational error, a D-optimal design also minimizes the maximal variance of the estimated response within the design region $\mathrm{X}$ :

$$
\mathrm{d}_{\max } \max _{\mathrm{x} \in \mathrm{X}} \mathrm{d}(\mathrm{x}),
$$

where

$$
\mathrm{d}(\mathrm{x}) \quad \operatorname{Var}\left[\sum_{\alpha 1}^{\mathrm{m}} \theta_{\alpha} \mathrm{x}_{\alpha}\right] .
$$

It is known that for any experimental design, $d_{\max } \leq \sigma^{2}(\mathrm{~m}+1) / \mathrm{N}$, where $\sigma^{2}$ is the variance of observational errors and $\mathrm{N}$ is the total number of available observations. 
It is known that for any experimental design, $d_{\max } \leq \sigma^{2}(m+1) / N$, where $\sigma^{2}$ is the variance of observational errors and $\mathrm{N}$ is the total number of available observations.

\subsection{CONSTRUCTION OF D-OPTIMAL DESIGN FOR INITIAL DESIGN}

To numerically construct a D-optimal design, we used the Fedorov-Wynn algorithm (see refs. 37 and 38). Various modifications of this algorithm are available, for instance, in statistical packages such as SAS ${ }^{39}$ and ECHIP. ${ }^{40}$ We have an in-house version of the algorithm coded by D. Flanagan (Statistics Group, Computer Science and Mathematics Division). Similar software was developed at ORNL by T. J. Mitchell. ${ }^{41}$ The total number of possible observations was selected to be equal to 47 . To ensure that we can easily trace some unusual observations during the analysis phase, it was prescribed to have two observations for some design points. The efficiencies of the better designs were around 0.8 (upper bound is 1 ). In this study, the efficiency was defined as the ratio $d_{\max } / d_{c o m}$, where $d_{c o m}$ is the maximal variance of the estimated response for the computed design and $\mathrm{d}_{\max }$ is the maximal variance for the D-optimal design.

For an exact $\mathrm{D}$-optimal design, the $\mathrm{d}_{\max } / \mathrm{d}_{\text {com }}$ ratio must be 1 (see details and justification in refs. 37 and 38). The value 0.8 is considered very good for practical needs. We added two extra "central" points (with two observations at each of them). These two points correspond to the estimation concerning the best solidifying mixture (which is based on the prior experience of the experimental group) and may be used to test the linear model vs the quadratic alternative.

The MWFA developed two standard surrogates for use in the studies of stabilization of high-salt wastes. The MWFA recipes for these two standard surrogates are listed in Table 1. The MWFA was concerned that the lack of any grout formulations with a combination of sulfate and chloride salts, as specified in the high chloride surrogate, would disadvantage this study against other alternative studies. For this reason, salt combinations were included in the design, and the constrained region was expanded so that the nitrate salt in the waste solids could be as high as 70 wt $\%$ (i.e., $x_{7} \leq 0.7$ ).

The resulting design used for laboratory testing, including two center points and their replicates added to the D-optimal design, is given in Table 2. 


\subsection{SLUDGE USED IN LABORATORY TESTING}

Originally, a sample of an actual mixed-waste salty sludge [i.e., electrochemical machining (ECM) sludge] was to be used alone in the statistical design, although supplemented by reagent-grade salts to make the salt compositions in the design. As the name indicates, this sludge was generated during electrochemical machining operations at theY-12 Plant and several drums of it have been stored at the East Tennessee Technology Park in Oak Ridge. These stored drums of sludge come in two apparent types: (1) a thick, bright yellow (high-uranium-content) slurry, appearing much like a thick mustard, and (2) a darker-colored slurry apparently contaminated with organics. One 55-gal drum of the bright yellow sludge was obtained for the studies reported here. The sludge in this drum was mixed as well as possible using a mortar mixer impeller on a hand-held drill motor, and four large subsamples were taken and stored in 5-gal buckets. Each subsample was mixed in a similar manner, and five analytical subsamples were taken from the center and four quadrants of each bucket, respectively. The samples were then submitted for analyses of moisture content (loss on drying) and the total concentrations of chloride, nitrate, sulfate, and Resource Conservation and Recovery Act (RCRA) metals. Table 3

lists the individual measured concentrations, and Table 4 lists the average concentrations, standard deviations, and percent relative standard deviation values (\% RSD, standard deviation divided by the mean and multiplied by 100 ) for the significant concentrations in Table 4 . The $\%$ RSD values listed in Table 4 indicate acceptable homogeneity for these mixed-waste sludge subsamples. The water content of the sludges was considered too high, so some water was evaporated from each drum prior to use in the laboratory. The evaporation was "gentle" (each drum was heated at $50-60^{\circ} \mathrm{C}$ in an oven) to prevent mineral formation or salt crusting on the sludge surface, and each sludge was mixed again with the mortar mixer after evaporation. The moisture contents were adjusted to $57.5,57.1,43.7$, and 57.7 wt $\%$ for buckets $1,2,3$, and 4 , respectively, with corresponding increases in the solids concentrations.

After the MWFA developed surrogates, these surrogates were included in the experiments with the ECM sludge. It was decided to use a combination of the ECM sludge and the components of the MWFA surrogates in laboratory testing. The MWFA surrogate components 
were allowed to dictate the salt and RCRA species used in laboratory testing, with the exception of the speciation of the nitrate already present in the ECM sludge. In data evaluation and presentation of results, the nitrate, chromium, and nickel contents of the ECM sludge were included with the reagent-grade salts added for calculating grout compositions. This meant that calcium sulfate, rather than sodium sulfate, was used with the salts and that chromium trioxide and mercuric oxide, rather than sodium dichromate and mercuric chloride, were used with the RCRA metal compounds.

Note that in Table 3 the ECM sludge contains a significant amount of nitrate but insignificant amounts of chloride or sulfate. Thus, the strategy adopted for the initial design was to use the ECM sludge as the source of nitrate for the waste solids in the design. The "other solids" fraction of the ECM sludge made up a portion of the other solids required in the design, and the remainder was supplied by the reagent-grade solids other than salts listed in Table 1 for the MWFA components. The portland cement listed in Table 2 was not included in the MWFA other solids, because it is also one of the design variables making up the dry blend. Thus, the MWFA other solids consisted of iron oxide, aluminum hydroxide, sodium phosphate, magnesium hydroxide, and calcium silicate. The reagent-grade sodium phosphate contained 12 waters of hydration. Although Table 1 does not show these waters of hydration, it was assumed that the relative composition listed in Table 1 for sodium phosphate was for this hydrated species, rather than for the anhydrous compound. The ECM wet sludge and wet sludge made from these MWFA components are illustrated in the photograph presented in Fig. 1, along with a typical grout made from each. If the other solids in the design would be exceeded by using the ECM sludge to provide all of the nitrate, then the ECM sludge was limited by the amount needed to supply the required amount of other solids and the remainder of the nitrate was provided by reagent-grade sodium nitrate. If no nitrate was needed in the design composition, then no ECM sludge was used, and all of the other solids were supplied by the reagent-grade MWFA components. Both the sodium chloride and the calcium sulfate were reagent-grade chemicals.

Water was the only ingredient determined during grout preparation. Table 2 lists qualitative guidance for water content in the last column as +1 or -1 . During preparation, -1 was defined as adding the minimum amount to make a mixable paste, even if quite stiff, and +1 was 
defined as achieving the -1 stage and then adding slightly more water to make the material more processible.

The grout compositions for the initial design resulting from the above strategy are listed in Table 5; more details of the wet sludge composition are listed in Table 6.

\subsection{RESULTS FROM THE INITIAL DESIGN}

Most of these grouts required more water than originally anticipated, with the water/solids ratio (W/S) ranging from 0.33 to 1.38 , thus, the solids and salts were diluted more than expected. Consequently, the salt loading varied from 1.1 to $27.1 \mathrm{wt} \%$ for the initial design, with individual ranges of $0-9.9,0-7.2$, and $0-27.1 \mathrm{wt} \%$ for calcium sulfate, sodium chloride, and sodium nitrate, respectively. Part of the high water demand and the difficulty in making wet, mixable pastes can be explained by the use of anhydrous powders of calcium sulfate and calcium silicate, in addition to the water demand of the stabilizing dry blend. The former hydrates with water to form a hard solid (i.e., Plaster of Paris). The latter is a dry, fluffy powder with a small mass taking up a large volume and requiring significant amounts of water to make into a wet, mixable paste. Thus, these two components of the MWFA surrogate will hydrate a significant amount of water; however, the ECM sludge appeared to require a significant amount of water in its grouts as well.

Tables 7 and 8 list the results obtained by performance testing the grouts from the initial design. The grout densities varied from 1.27 to $1.86 \mathrm{~g} / \mathrm{mL}$. Since the wet sludges were complex combinations of actual mixed-waste sludge (ECM sludge), MWFA other solids, and salts, no single measurement of sludge density would correspond to the wet sludge used in a particular grout composition for calculating the ratio of the grout volume to the wet sludge volume. Thus, to calculate this volume ratio, the density of the wet sludge was estimated, assuming additive volumes, from the measured density of the ECM sludge $(1.385 \mathrm{~g} / \mathrm{mL})$ and the reported densities of the other compounds, salts, and water used to make the wet sludge. This estimated density of the wet sludge was used with the measured grout density and the wet-sludge loading in the grout to calculate the ratio of the volume of the grout to the volume of the wet sludge used to make the 
grout. From these volume ratios listed in Table 8, the grouts of the initial design had a volume increase ranging from 11 to 71 vol \% for total wet-sludge loadings ranging from 41 to $79 \mathrm{wt} \%$.

The TCLP analysis for this set of grouts is complete. All of the listed TCLP extract concentrations for the initial design grouts were within the Universal Treatment Standard (UTS) limits, except for chromium for several grouts. All of the grouts in the initial design failing to meet UTS chromium limits had no slag in the grout composition. Although some grouts without slag did meet UTS chromium criteria, none with slag failed. This definitively establishes that slag effectively stabilizes $\mathrm{Cr}(\mathrm{VI})$, which was added as the oxide species in these grouts [speciation of the chromium in the ECM sludge was unknown, but the soluble species extracted was assumed to be $\mathrm{Cr}(\mathrm{VI})$ in this work].

None of the grouts from the initial design had any free water after $28 \mathrm{~d}$; only one (test 33 ) had any free water within $1 \mathrm{~d}$, and this free water was gone within $3 \mathrm{~d}$.

Few of the grouts in the initial design failed to harden and to exhibit significant compressive strengths. The compressive strengths ranged from 0 to $6600 \mathrm{psi}$. The compressive strengths from the initial design were evaluated statistically to generate a preliminary model to use in defining the constraints for the subsequent design, focusing on the higher loadings.

\subsection{PRELIMINARY COMPRESSIVE-STRENGTH MODEL FROM THE INITIAL DESIGN}

The initial design obtained the baseline data needed to verify the important constituents that contribute to compressive strength, a TDRD performance criterion, and to extrapolate to the compositions needed for the critical value of this property (500 psi). To accomplish these objectives, both the compressive strength data (Table 7) and the design data (Table 2) were subjected to regression analysis to find the best empirical second-order model to calculate the compressive strength as a function of the compositional design variables. As expected, the regression analysis indicated that the unconfined compressive strength (UCS) was a strong function of the cement and slag contents. The analysis also indicated that the fly ash and the clay had no effect on the strength, except the indirect effect of diluting cement and slag. The preliminary empirical model for this initial data set is as follows: 


$$
\ln (\mathrm{UCS}, \mathrm{psi})=5.98+0.3 \mathrm{x}_{1}+0.731 \mathrm{x}_{2}^{2}+0.825 \mathrm{x}_{7}
$$

where $\ln$ refers to the natural logarithm and the variables $x_{1}, x_{2}$, and $x_{7}$ represent the cement, slag, and nitrate contents, respectively.

The positive dependence on the nitrate salt was unexpected because the nitrate salt is not expected to contribute to the grout strength. This dependence in the regression model was interpreted as a significant difference between the performance of the ECM sludge and that of the surrogate sludge made with MWFA components. Since ECM sludge was used to supply nitrate in the formulations, even though supplemented with reagent-grade sodium nitrate, the implication is that the ECM sludge forms a stronger grout than that formed from the MWFA components. For this reason, the subsequent design was tested separately on the ECM sludge and surrogate MWFA components. The lack of a negative impact from salts in the model is important, implying that the salt content or composition will not negatively impact the strength. Thus, the subsequent design focused on the compressive strength limit of 500 psi in the criteria.

The contour equation for a compressive strength of 500 psi was determined for this model by assigning a constant value of 500 psi to the strength in the equation. Figure 2 illustrates the contour lines of 500 psi predicted by the model for nitrate mass fractions in the waste solids $\left(\mathrm{x}_{7}\right)$ of 0.0 and 0.7 . The region to the left and below the constraint line and below zero is outside the constrained region (the empirical model is not applicable outside the constrained region). Figure 2 illustrates that only a small region in the constrained region below the line for $x_{7}=0.7$ is predicted to have a compressive strength below 500 psi. If no clay was present in the grout, then almost any combination of nonzero slag and cement led to average compressive strengths $>500$ psi within the constrained region.

This prediction, along with the results discussed above, gave confidence that the constrained region for the subsequent design, as focused on the higher loadings, would have measurable compressive strengths close to, or higher than, $500 \mathrm{psi}$. Both the model and the TCLP performance favor high slag contents. Therefore, in addition to eliminating fly ash and clay from the dry blend as noncontributors to strength, the dry blend was constrained to higher slag contents in the subsequent design. The implementation of the recommended NRC criteria, with its 
emphasis on relatively strong cementitious waste forms, in the TDRD, subsequent to the original proposal for the present work, made the original proposition of a more plastic matrix using high clay contents purely academic. By definition, such a matrix would flow under unconfined compression and would not meet the recommended criteria for unconfined compressive strength. Such a plastic matrix could still be an alternative for wastes that lead to the formation of expansive minerals during long-term storage, if the less stringent criteria for unconfined compressive strength of noncementitious waste forms are applied.

\section{SECOND-STAGE EXPERIMENT}

The basis for statistical design and logic for the generation of D-optimal designs is the same as that for the initial design. The initial design established the baseline performance for the salt performance of grouts extending into the well-established region of performance referred to by the MWFA, $<10 \mathrm{wt} \%$ salt loadings. The subsequent design redefined the constrained region, focusing on a region of high loadings that were still expected to give reasonable performance.

\subsection{CONSTRUCTION OF D-OPTIMAL DESIGN FOR THE SECOND STAGE}

The design region was defined for the subsequent design in the following manner: (1) the mass fraction of salt in the waste solids was fixed at 0.7 , (2) the ECM sludge and MWFA other solids would be treated separately, (3) no clay or fly ash was present, (4) the ratios of slag and cement to the unit waste solids varied from 0.25 to 0.5 , (5) the ratio of cement to slag was at least 0.2 in order to activate the slag, (6) the salt composition of the waste solids would will be allowed to vary between replicates of grout composition, and (7) the water content would always be at a minimum. Thus, the design region is defined by the following relationships:

$$
\begin{aligned}
& x_{5}+x_{6}+x_{7}+\text { other solids }=1 \text { (one unit weight) } \\
& x_{5}+x_{6}+x_{7}=0.7 \\
& \text { other solids }=0.3
\end{aligned}
$$


$\mathrm{x}_{3}=\mathrm{x}_{4}=0$

$0.25 \leq x_{1}+x_{2} \leq 0.5$

$x_{1} \geq 0.2 x_{2}$

The other solids term refers to the other solids that come with the ECM sludge or are made up from the MWFA other solids. In the case of the ECM sludge grouts, the other solids dictated the quantity of ECM sludge used, and the required residual nitrate content was added as reagentgrade sodium nitrate. Since the ECM sludge contained insignificant amounts of chloride and sulfate, these two salts were added as reagent-grade chemicals. The MWFA grouts were prepared as surrogate sludges using reagent-grade chemicals.

Table 9 lists the components of the computed D-optimal design. The sludge source is listed as 0 and +1 for the separate testing of the MWFA-type surrogate sludge and the ECM actual mixed-waste sludge, respectively. High and low values of the sulfate and chloride were left for later definition as +1 and -1 , with the nitrate content to be defined by the difference between the fixed salt fraction in the waste solids of 0.7 and the sum of the mass fractions of these other two salts. Since the sulfate and chloride mass fractions in the standard MWFA waste solids are 0.07 and 0.14 , respectively (calculated from Table 1), the high and low values were set at 0.10 and 0 for sulfate and 0.20 and 0 for chloride. Table 9 also lists the sludge source and salt composition of the waste solids resulting from these definitions of the high and low values. All of the water contents were -1 for the subsequent design.

\subsection{RESULTS}

Tables 10 and 11 list the final grout compositions resulting from the subsequent design after minimum water was added to make the grouts into wet, mixable pastes. The order listed in Table 9 was randomized, and Table 10 is listed according to the randomized test numbers. In general, the grouts from the subsequent design proved less "water demanding" than those from the initial design, as witnessed by the W/S ratios listed in Tables 10 and 5. From Table 10, the MWFA grouts (W/S $=0.32-0.50)$ required less water than the $E C M$ grouts $(W / S=0.40-0.69)$. 
The final wet-sludge loading ranged from 76.2 to $88.2 \mathrm{wt} \%$ for the ECM grouts and from 74.4 to 85.4 wt $\%$ for the MWFA grouts.

Tables 12 and 13 list the performance test results for grouts formulated according to the sequential design. These results are presented according to trial number to facilitate comparison of grout compositional replicates. (These are not true replicates, since the salt composition was allowed to vary.) Surprisingly, over half the grouts failed to set and harden to give measurable compressive strengths. Such results hindered statistical evaluation and made it unlikely that a predictive empirical model could be generated from this data set. These results imply a phase transition region in the surface response within the constrained composition region, but the data are too limited to define this phase transition region. Apparently the extension beyond the previous constrained region of the initial design was overly optimistic in our attempt to explore the limits of salt loading. Some of the compressive strength results for the MWFA grouts are not consistent, perhaps even contradictory. For trials $1,2,11$, and 32, grouts of apparently the same composition harden to give a measurable compressive strength in one case and fail to harden in another. The only differences in composition between these "replicates" is the salt composition. However, in some cases, a higher nitrate content appears to lead to set failure, while in other cases, a higher chloride-sulfate content appears to lead to set failure. On the one hand, compressive strengths $>500$ psi were achieved with salt loadings $>40 \mathrm{wt} \%$, but the salts definitely affected the set at these high loadings.

None of the grouts had any free water after $28 \mathrm{~d}$ or showed any tendency to form any free water during the 28-d cure. Some of the calculated volume ratios indicate a volume decrease for the ECM grouts, which is not likely for the ECM sludge. Dry waste can contain a significant number of air voids and will collapse when wet and mixed to form a paste to give a net bulk volume decrease; however, the ECM sludge is fairly stiff and smooth, with no evidence of air voids. Adding a dry blend to this wet sludge almost certainly results in a volume increase-not a volume decrease, as calculated in several cases in Table 12. Thus, there is a significant error in this calculation, which is likely caused by the assumed constant sludge density used in these calculations and should be viewed as a rough estimate only. Suffice it to say that the volume increase is likely $<15 \mathrm{vol} \%$ for the ECM grouts in Table 12 . The calculated volume increases for 
the MWFA grouts ranged from 3 to $20 \mathrm{vol} \%$. The additive volume technique used for estimating the varying MWFA sludge composition predicted the measured MWFA wet sludge density within about $1 \%$.

The TCLP extract concentrations of nickel, lead, and mercury were consistently within the UTS limits for the grout formulations in the sequential design. These results confirmed the effect of slag on the TCLP performance for chromium. The initial design grouts passed the test limit for chromium if slag was included in the grout. The sequential design grouts indicate that slag is needed to stabilize chromium trioxide at the levels spiked, and also that a minimum level of slag is needed. Figure 3 illustrates the effect of the slag content of the grout on the fraction of chromium extracted during TCLP testing for both the initial and the sequential designs. The final chromium concentration of these grouts depends on the chromium concentration in the waste and the waste loading of the grout. A TCLP extract concentration of $0.86 \mathrm{mg} / \mathrm{L}$ (the UTS limit) represents an extraction of $0.17 \mathrm{wt} \%$ from $1000 \mathrm{mg} / \mathrm{kg}$ of chromium in the grout. Figure 3 indicates that the final grout should consist of $\geq 9 \mathrm{wt} \%$ slag to ensure meeting the UTS standard.

Although all TCLP extract concentrations but one meet the UTS limit for cadmium of $0.19 \mathrm{mg} / \mathrm{L}$, some measurable cadmium extract concentrations did appear, and one relatively high value of $2.6 \mathrm{mg} / \mathrm{L}$ was present. In general, cadmium is effectively stabilized by $\mathrm{pH}$ control, so cementitious waste forms are typically quite effective at stabilizing cadmium. Chromium(VI) is not effectively stabilized by simple $\mathrm{pH}$ control; hence, a reducing agent such as slag, is required. The higher concentrations of cadmium in the sequential design do not appear to be related to cement or binder content, but rather to high wet sludge loadings. The fraction of cadmium extracted during TCLP analysis is plotted vs the final wet sludge loading of the grouts for both the initial and sequential designs in Fig. 4, illustrating little evidence of correlation except for one high extraction at high loading. At the wet sludge loading for this point, the grout may have lost its ability to maintain a high $\mathrm{pH}$ in the TCLP acetic acid extract, resulting in the high cadmium extraction. The wet sludge loading is limited not only by a minimum slag content required to reduce $\mathrm{Cr}(\mathrm{VI})$, but also by a minimum binder content to maintain buffering $\mathrm{pH}$ control to stabilize those RCRA metals sensitive to $\mathrm{pH}$. Such results indicate that the limits are being approached for the sludges and RCRA metal concentrations studied with a wet sludge loading of about $90 \mathrm{wt} \%$. 
Since the exact maximum upper limit is unclear, it may be possible for a wet sludge loading of $>90 \mathrm{wt} \%$ to meet TCLP UTS limits; however, it is clear that such high sludge loadings are beginning to compromise the stabilization potential of the dry blend.

\subsection{REGRESSION ANALYSIS OF THE RESULTS OF THE INITIAL AND SEQUENTIAL DESIGNS}

Although the sequential-design experiment was meant to complement the initial-design effort and reveal more details about the surface response at higher loadings, the lack of measurable values for the compressive strength in many cases in the sequential design indicates that the sequential design was focused in a phase transition region of the surface response. Since there are insufficient data to define this phase transition, it was risky to model the combined results of the two designs. For this reason, the two designs were modeled separately.

The main objective was to select a parsimonious model that would reliably describe the data presented in Tables 7 and 8 . The only data that could be reliably modeled were those for the UCS and the chromium TCLP performance from the initial design.

Beginning the analysis with UCS, the model under consideration included two random components and was slightly more complicated than (Eq. 3):

$$
\mathrm{y}_{\mathrm{ij}}=\eta\left(\mathrm{x}_{\mathrm{i}}, \theta\right)+\varepsilon_{\mathrm{i}}+\mathrm{e}_{\mathrm{ij}} \cdot
$$

The first term, $\eta\left(\mathrm{x}_{\mathrm{i}}, \theta\right)$, describes some average dependence of the response variable on the selected set of factors. The random variable, $\varepsilon_{\mathfrak{i}}$, corresponds to randomness (variability), which appears in the process of sample preparation for a given $\mathrm{x}_{\mathrm{i}}$. The random variable, $\mathrm{e}_{\mathrm{ij}}$, describes the differences arising when, for instance, $y_{i j}=\ln \left(U C S_{i j}\right)$ was measured three times (i.e., three cubes were generated for each grout batch and their compressive strengths measured). In the model fitting, it was assumed that for all $\mathrm{x}_{\mathrm{i}}$, the random components $\varepsilon_{i}$ and $\mathrm{e}_{\mathrm{ij}}$ have the same variance (i.e., $\operatorname{Var} \varepsilon_{i} \equiv$ constant and $\operatorname{Var} e_{i j} \equiv$ constant). The analysis found $\operatorname{Var} e_{i j} \ll \operatorname{Var} \varepsilon_{i j}$; therefore, the average of the three observations [e.g., $\left.y_{i}=1 / 3\left(\ln U_{C S}+\ln U C S_{i 2}+\ln U C S_{i 3}\right)\right]$, was used in the analysis. The logarithmic transform gives better approximations for some simple linear models. 
Deletion of a single observation, discussed below, removed the need for the logarithmic transformation for the compressive strength data from the initial design.

The D-optimal approach proposed for the initial design was used under the assumption that the simple linear model of Eq. (2) is true. However, the optimal design, which has significantly more experimental points than the number of unknown parameters (i.e., $m=9$ ), was selected, and four central points were added (only grouts with measurable compressive strengths were used in modeling, so the two central points with no compressive strength were not used during analysis), resulting in the initial design compositions listed in Table 5. The extra points permit attempts to fit different types of models that may include interactions and quadratic terms. "Stepwise regression" and "the best subset regression" were used to statistically select the best model(s) (ref. 42, Chap 12). The stepwise regression was applied when all interactions and quadratic terms $[\mathrm{m}(\mathrm{m}+1) / 2=45]$ were included in the analysis. A relatively small number of the best candidates $(\sim 10)$ were explored with the best subset regression approach. Mallow's $C_{m}$ statistics were used as a formal criterion of model selection (see ref. 42, Chap. 12). In addition to this relatively complicated criterion, two other statistical terms were used in evaluating the models: (1) the sum of the squared residuals, $\mathrm{s}^{2}$; and (2) the coefficient of determination, $\mathrm{R}^{2}$, often referred to as the correlation coefficient (see ref. 42, Chap. 4 for definitions of these terms and more detail). When several models had approximately the same value of $C_{m}$, the preference was given to those with smaller values of $s^{2}$ and larger values of $R^{2}$.

Note that there are a few problematic observations. Four observations with zero compressive strength were removed from the analysis. Observation No. 23, which has $>6,750 \mathrm{psi}$, distorted the analysis, such that its removal gives an almost perfect statistical fit for the linear model, which is more compatible with the sequential design results. Deleting this observation removed the need to consider various models.

The results of the response surface regression for the average unconfined compressive strength (avg UCS) from the initial design recommended for use are shown in tabular form, as follows: 


\begin{tabular}{lcccc}
\hline \multicolumn{1}{c}{ Term } & Coefficient & $\begin{array}{c}\text { Standard } \\
\text { deviation }\end{array}$ & t-ratio & $\mathrm{p}$ \\
\hline Constant & -526 & 344 & -1.53 & 0.134 \\
$\mathrm{x}_{1}$ (cement) & 1153 & 108 & 10.7 & 0.000 \\
$\mathrm{x}_{2}$ (slag) & 806 & 123 & 6.54 & 0.000 \\
$\mathrm{x}_{3}$ (clay) & -3253 & 486 & -7.25 & 0.000 \\
$\mathrm{x}_{5}$ (chloride) & 3693 & 828 & 4.45 & 0.000 \\
$\mathrm{x}_{6}$ (sulfate) & 1747 & 836 & 2.09 & 0.043 \\
$\mathrm{x}_{7}$ (nitrate) & 2152 & 415 & 5.18 & 0.000 \\
$\mathrm{x}_{8}$ (water) & -309 & 95 & -3.24 & 0.002 \\
$\mathrm{~s}=640.7$ & $\mathrm{R}^{2}=83.6 \%$ & $\mathrm{R}^{2}$ (adj) $=80.6 \%$ & & \\
\hline
\end{tabular}

Note that all the salts are statistically significant, although sulfate $\left(\mathrm{x}_{6}\right)$ is near the statistical limit (the t-ratio, or coefficient divided by its standard deviation, is close to 2). These coefficients lead to the following equation, which predicts the average unconfined compressive strength as a function of grout composition:

avg UCS (psi) $=-526+1153 x_{1}+806 x_{2}-3523 x_{3}+3693 x_{5}+1747 x_{6}+2151 x_{7}-309 x_{8}$

Plots of the standard residuals and the predicted strength vs the observed strength for this model are included in the appendix, along with statistical printouts of the regression. No serious differences occur within the region allocated for the $\mathrm{D}$-optimal design. Figure 5 illustrates contour plots of lines of constant compressive strength as a function of cement and slag composition, holding the other variables constant at their median values for the undeleted observations in Table $7\left(x_{3}=0.21, x_{5}=0, x_{6}=0, x_{7}=0.4\right.$, and $\left.x_{8}=-1\right)$. Superimposed is the "slice" of the constrained region as viewed on this two-dimensional plot. Note that strength is 
predicted to increase with cement or slag and that the critical value of $500 \mathrm{psi}$ appears to lie outside the constrained region.

The results of the response surface regression for the percentage of chromium extracted during TCLP testing $(\% \mathrm{Cr})$ from the initial design recommended for use are as follows:

\begin{tabular}{lcccc}
\hline \multicolumn{1}{c}{ Term } & Coefficient & $\begin{array}{c}\text { Standard } \\
\text { deviation }\end{array}$ & t-ratio & $\mathrm{p}$ \\
\hline Constant & -4.59 & 23.3 & 0.197 & 0.846 \\
$\mathrm{x}_{1}$ (cement) & 90.5 & 42.7 & 2.12 & 0.045 \\
$\mathrm{x}_{2}$ (slag) & -16.0 & 37.8 & -0.424 & 0.676 \\
$\mathrm{x}_{1}{ }^{2}$ & -32.3 & 12.7 & -2.54 & 0.018 \\
$\mathrm{x}_{2}{ }^{2}$ & 2.37 & 13.8 & 0.172 & 0.865 \\
$\mathrm{~s}=10.22$ & $\mathrm{R}^{2}=77.0 \%$ & $\mathrm{R}^{2}$ (adj) $=73.0 \%$ & & \\
\hline
\end{tabular}

The statistical fit for this model is clearly poorer than that for the average UCS. The equation resulting from this regression is as follows:

$$
\% \mathrm{Cr}=-4.59+90.5 \mathrm{x}_{1}-16.0 \mathrm{x}_{2}-32.3 \mathrm{x}_{1}{ }^{2}+2.37 \mathrm{x}_{2}{ }^{2} \text {. }
$$

The first-order terms in the model agree with the general observation that TCLP chromium failure in the initial design only occurred when there was no slag in the grout and is consistent with the mechanistic understanding that slag is reducing (thereby helping to stabilize chromates) and cement is oxidizing (thereby preventing chromate reduction). Consequently, the model is presented as the best fit for the data that should indicate general trends, but its predicted values should be viewed cautiously. The second-order terms result in the dependent variable passing through a maximum, as illustrated on the contour plot of this model in Fig. 6. It is less clear how accurate this prediction is, although it is consistent with the observations used to generate the model. 
For the sequential design analysis, only the compressive strength was evaluated and the observations with zero compressive strength were deleted. The results of the response surface regression for the average (avg) UCS from the sequential design recommended for use are as follows:

\begin{tabular}{lcccc}
\hline \multicolumn{1}{c}{ Term } & Coefficient & $\begin{array}{c}\text { Standard } \\
\text { deviation }\end{array}$ & t-ratio & $\mathrm{p}$ \\
\hline Constant & -117 & 382 & -0.306 & 0.766 \\
$\mathrm{x}_{1}$ (cement) & 2196 & 736 & 2.99 & 0.014 \\
$\mathrm{x}_{2}$ (slag) & 2228 & 608 & 3.66 & 0.004 \\
$\mathrm{x}_{6}$ (sulfate) & -2439 & 1197 & -2.04 & 0.069 \\
$\mathrm{x}_{7}$ (nitrate) & 350 & 557 & 0.629 & 0.544 \\
$\mathrm{x}_{9}$ (sludge type) & -620 & 123 & -5.04 & 0.000 \\
& & & & \\
$\mathrm{~s}=207.9$ & $\mathrm{R}^{2}=80.6 \%$ & $\mathrm{R}^{2}(\mathrm{adj})=70.9 \%$ & & \\
\hline
\end{tabular}

Note that a new variable, $x_{9}$, was introduced to represent the sludge types MWFA and ECM. This was a qualitative variable, such as $\mathrm{x}_{8}$, except that it was assigned the values +1 and 0 for ECM and MWFA, respectively. The statistical validity for this new variable proved to be stronger than that for the other variables (i.e., the ECM sludge made significantly weaker grouts than those prepared by using MWFA surrogate components). The nitrate term is not statistically valid, indicating that model may be over-parameterized or that more data are needed to accurately model the constrained region. Only two salts can be included independently in the model, since the sum of the salt variables for the sequential design must be kept constant at 0.7 . The model selected for nonzero compressive strength in the sequential design by this analysis follows:

$$
\operatorname{avg} U C S=-117+2196 x_{1}+2228 x_{2}-2439 x_{6}+350 x_{7}-620 x_{9} \text {. }
$$

The statistical printouts for the generation of the three models presented in this section are given in the appendix. 


\section{TESTS USING STANDARD MWFA SURROGATE SLUDGES}

\subsection{VARYING SLUDGE LOADING}

In addition to the statistical designs and attempts to model the surface responses of the grouts, a simple series of tests was conducted using each of the standard MWFA surrogate sludges listed in Table 1, including surrogate sludges containing cement but without the trichloroethylene contaminant. The nominal loadings of the standard sludge mixed with the dry blend for these tests were $90,80,70,60$, and $50 \mathrm{wt} \%$. However, the standard surrogates were quite dry, as

illustrated in Fig.7, and required the addition of a significant volume of water to make a wet, mixable paste that could be processed into a grout. This extra water significantly diluted the original standard sludge and dry blend loading in the final grouts. Table 14 lists the final compositions of these grouts in terms of the content of the standard sludge, dry blend, and added water. The final standard surrogate loadings ranged from 36 to $77 \mathrm{wt} \%$ after the water additions. The salt loadings ranged from 5 to $46 \mathrm{wt} \%$. The total wet-sludge loadings (standard sludge loading plus added water) for these grouts ranged from 57 to $93 \mathrm{wt} \%$. The high-chloride surrogate proved more water demanding than did the high-nitrate surrogate, with the W/S ratio ranging from 0.64 to 0.91 as compared with $0.26-0.34$. This result is not too surprising since the high-chloride surrogate contained calcium sulfate and the high-nitrate surrogate did not. The W/S ratio for of the high-nitrate surrogate grouts was lower than expected, based on the previous design results. (It is not clear whether the addition of $\mathrm{NaOH}$ as an activating agent in these grouts had any effect on the water demand characteristics.)

Based on the results for the design, the dry blend selected for these tests was $90 \mathrm{wt} \%$ slag and $10 \mathrm{wt} \%$ cement. In addition, the results for the sequential design clearly demonstrated the set retardation effects of the high contents of these salts. Such results indicated that activation of the slag was needed to overcome the retardation effects of the salts. For this reason, the $\mathrm{pH}$ of each of the surrogate sludges was adjusted to $12-13$ (as tested by $\mathrm{pH}$ paper strips), using $10 \mathrm{~N} \mathrm{NaOH}$ after water had been added to the standard sludges to make the sludge into a wet, mixable paste. (The starting $\mathrm{pH}$ of the wet, mixable pastes was about 11.) This addition of $\mathrm{NaOH}$ will activate the 
slag, leading to a more rapid set and early strength development-important factors for this study since one of the criteria is a minimum compressive strength.

Tables 15 and 16 list the performance test results for these grouts. Note that the volume ratio is calculated both on the basis of the original, fairly dry standard surrogate and after water addition to make the surrogate a wet, mixable paste. A volume decrease of up to a factor of 2 or more is calculated for these grouts because of the large number of air voids in the fairly dry standard surrogates. The calcium silicate, in particular, adds a large volume of light fluffy solids. Wetting these solids with enough water to make a wet, mixable paste collapses the large bulk volume, thereby eliminating the air voids and making a much denser sludge and grout. The uncompacted bulk specific gravity of each standard surrogate was less than $1-0.52$ and 0.92 for the high-chloride and high-nitrate surrogates respectively (dumped and vibrated, but not compacted). The corresponding specific gravities for the wet sludge after adding water to form wet, mixable pastes were 1.38 and 1.68 for the high-chloride and the high-nitrate sludges, respectively.

The volume increase for the grout mixtures, over the wet sludges, ranged from 3 to $72 \mathrm{vol} \%$, depending on the loading and the type of surrogate used. As ususal, the grouts had no problem with free water.

As expected, activating the slag resulted in quicker sets and higher compressive strengths. The compressive strengths ranged from 210 to 3858 psi. Only the highest loading of the highnitrate surrogate had an average compressive strength of $<500 \mathrm{psi}$, and none failed to set.

Table 16 summarizes the TCLP performance of these grouts. Only the high-chloride surrogate at the highest loading failed to meet UTS limits, exceeding the limit for chromium. Note that the high-chloride surrogate sludge is only characteristically hazardous for chromium, while the high-nitrate surrogate sludge is characteristically hazardous for cadmium and chromium. Both standard sludges are partially stabilized by the presence of cement in the surrogate. As shown in Table 17, the high-chloride surrogate is apparently more effectively stabilized than the high-nitrate surrogate, presumably because of the relatively higher cement content (the lower salt content for the high-chloride surrogate leads to higher contents of all the other solids) and the use 
of calcium sulfate as the sulfate salt (calcium sulfate is the solidifying agent for one commercial waste form, Envirostone $($ )).

Tables 17 and 18 list the compositions of these grouts on the same basis as that reported for the earlier designs. In calculating these compositions, the cement in the standard surrogate was included in the dry blend but was not included in the wet sludge; thus, the wet sludge and dry blend contents do not agree between Tables 14 and 17.

\subsection{VARYING THE CHLORIDE AND SULFATE LOADINGS}

Salt loadings $>40 \mathrm{wt} \%$ have been discussed in the results thus far. Sodium nitrate loadings $>40 \mathrm{wt} \%$ are included in these results, giving a fair representation of the nitrate contents of DOE wastes and the loading limit of slag-cement grouts in stabilizing high-nitrate wastes. Sodium chloride and calcium sulfate loadings ranged as high as about 12 and $10 \mathrm{wt} \%$, respectively. Although $\mathrm{DOE}$ wastes typically contain much less chloride and sulfate than nitrate, some cases of higher concentrations do exist at DOE sites. To more fully explore the effects of these two particular salts on grout performance, another set of simple experiments was conducted.

The strategy in this set of experiments was to fix the waste loading and to vary the chloride and sulfate contents of the waste. The nominal grout formulation was 50,25 , and $25 \mathrm{wt} \%$ waste solids, dry blend, and water, respectively. The waste solids consisted of the salt, other MWFA solids (excluding cement), and the RCRA compounds. Each salt, sodium chloride and calcium sulfate, was tested individually at final nominal grout loadings of 10, 20,30,40, and $49.625 \mathrm{wt} \%$. The other MWFA components and RCRA compounds made up the remainder of the nominal $50 \mathrm{wt} \%$ waste solids (the waste solids consisted of salt plus the RCRA compounds at the highest salt loading and contained no other MWFA components). Extra water was added, if needed, to make a wet, mixable paste, which would dilute the other components.

Tables 19 and 20 present the final compositions for these grouts, and Tables 21 and 22 summarize the performance test results. These results demonstrate cementitious loadings near $50 \mathrm{wt} \%$ of either chloride or sulfate, thereby meeting the performance criteria. The chloride grouts were quite fluid, especially at the higher salt loadings. The higher loadings even generated 
some free water early in the cure, indicating that water contents of $<25 \mathrm{wt} \%$ and higher salt loadings could have been used for the chloride grouts. The sulfate grouts were much stiffer than the chloride grouts, and the higher sulfate loadings required more water to make a wet, mixable paste. This was not surprising, since the sulfate salt was calcium sulfate. The strength declined with increasing chloride content, but increased with increasing sulfate content-again the result of using calcium sulfate as the sulfate salt. This strong contribution of calcium sulfate to grout strength was not as evident when used in combination with the chloride at low sulfate loadings (see the results listed in the previous tables). The prior results illustrate that the nitrate and chloride salts interfere with the set of the grout and lead to lower strengths at a given time in the construction standard 28-d cure; however, calcium sulfate, free of the other two salts, obviously contributes significantly to the final grout strength, especially for the alkali-activated slag grouts.

The grouts for both salts tested well above the criterion of 500-psi compressive strength, implying that a waste solids loading higher than $50 \mathrm{wt} \%$ could have been used to explore the individual salt loading. Interaction phenomena among the salts may help to explain some of the observed differences in strength from the statistical designs. The current data set was not sufficient to model such an interaction; and some, if not all, of the observed differences between the two latter data sets and the statistical designs may be explained by the use of alkali activation of the slag grouts in the latter data sets.

\section{SUMMARY AND CONCLUSIONS}

Slag grouts meeting the performance criteria (no free water, average compressive strengths $>500 \mathrm{psi}$, and falling within TCLP UTS limits) were generated with salt loadings approaching $50 \mathrm{wt} \%$, well above the MWFA goal of $>10 \mathrm{wt} \%$ salt loading. Loadings approaching $50 \mathrm{wt} \%$ were demonstrated individually for nitrate, chloride, and sulfate salts. Statistical design and analysis were used to generate empirical models for predicting compressive strength and chromium extracted during TCLP testing as a function of grout composition. The other performance properties, free water and TCLP performance of the remaining RCRA metals, proved relatively unchanged in the constrained region and, consequently, could not be modeled. The fact 
that the small variations in these other performance factors resulted in no models indicates that the other properties meet performance criteria over the entire constrained region.

Not surprisingly, cement and slag proved to be the best waste form matrix contributors to compressive strength, while clay had a strong negative effect on strength. Apparently, fly ash had an insignificant effect on strength in a 28-d cure. Fly ash, which is a well-known pozzolan, is eventually subsumed into the cementitious matrix, but only gradually over long times. Although fly ash is not a strong contributor to the waste form strength, it does influence the stabilization potential of cement waste forms by affecting the $\mathrm{pH}$ and chemistry of the waste form. It is possible that slag not only adequately substitutes for cement in providing strength, but also assumes the role of cement-fly ash combinations with regard to stabilization potential. Certainly, with regard to TCLP testing, the slag proved the equal of cement-fly ash in stabilizing the RCRA metals and also proved necessary to stabilize $\mathrm{Cr}(\mathrm{VI})$.

The salts certainly interfered with the grout set and retarded strength development, as demonstrated by the large number of grouts that failed to set in $28 \mathrm{~d}$ and had no compressive strength. The surface response is apparently complex, possibly containing a phase transition region at high salt loadings with nonactivated slag. These results make it clear that extrapolating the results from one waste or sludge to another can be risky and that testing with the actual waste or sludge is needed prior to final selection of a grout alternative. The results indicate that if the set retardation is overcome, the strength of the resulting monolith is more than adequate, even at quite high loadings. Alkali-activated slag apparently overcomes the set retardation of the salts, resulting in a strong final waste form at wet-sludge loadings up to about $90 \mathrm{wt} \%$. Waste loadings this high tend to dilute the stabilizing agents to such an extent that both strength and TCLP performance suffer. For this reason, the range of chloride and sulfate loadings was tested at a conservative wet sludge loading of $75 \mathrm{wt} \%$ and salt loadings approaching $50 \mathrm{wt} \%$. The strengths remained well above $500 \mathrm{psi}$, implying that salt loadings $>50 \mathrm{wt} \%$ were possible with subsequently smaller volume increases. In fact, the strengths increased as the calcium sulfate alone increased, which is not surprising since calcium sulfate hardens into a fairly strong material upon hydration. This behavior should not be considered typical for wastes, especially wet sludges, although it is possible that a dry waste or ash may contain anhydrous calcium sulfate or 
other reactive materials that can contribute significantly to the strength. This is another example of the complexity of dealing with actual wastes.

The interaction of the wastes with the stabilizing agents has the beneficial effect of stabilizing contaminants as low-solubility, leach-resistant species. Although physical encapsulation of the waste inside a strong monolithic solid makes the waste less leachable and protects the environment even more, the stabilization interactions means that the waste form is not dependent on the durability of this physical structure to protect the environment, as demonstrated in the size reduction required in the TCLP test. These salts also interact in undesirable ways, retarding the grout set and forming expansive minerals. Admixtures are available to accelerate the set, and alkali activation of the slag apparently worked to overcome these salt interference effects. The formation of expansive minerals over time was not studied in the short-term performance tests conducted in this work.

A net volume decrease occurred in mixing the standard MWFA surrogate sludges into grouts because these surrogates were relatively dry and the reagent-grade chemicals, especially the calcium silicate, were relatively fluffy (i.e., a lot of air was incorporated into the bulk volume). A net volume decrease can be expected for a dry waste, especially ashes, but actual wastes are not likely to be as fluffy as the calcium silicate; thus, the volume decrease will typically be less for an actual dry waste. Wet wastes and sludges are not likely to have air voids and typically will experience volume increases upon adding stabilizing agents and mixing into a grout. The ratio of the grout volume to the sludge volume is proportional to the bulk density of the sludge and inversely proportional to the bulk density of the grout and sludge loading.

In conclusion, cementitious waste forms can be used for final disposal with salt loadings of $50 \mathrm{wt} \%$ or higher, in principle, with volume increases as low as $10 \mathrm{vol} \%$ or less. Such results allow this mature and cheap technology to be strongly considered for the disposal of the large volumes of salty wastewaters and sludges across the DOE sites without the restriction of $<10 \mathrm{wt} \%$ loading and the subsequent large volume increases associated with such low loadings. 


\section{REFERENCES}

1. U.S. Nuclear Regulatory Commission, Technical Position on Waste Form (Revision 1), Office of Nuclear Material Safety and Safeguards, Division of Low-Level Waste Management and Decommissioning, January 1991.

2. R. D. Spence and T. M. Gilliam, Grout and Glass Performance in Support of Stabilization/Solidification of the MVST Tank Sludges, ORNL/TM-13652, September 1998.

3. R. D. Spence, C. H. Mattus, and A. J. Mattus, Grout and Glass Performance in Support of Stabilization/Solidification of ORNL Tank Sludges, ORNL/TM-13653, September 1998.

4. W. de Laguna, "Radioactive Waste Disposal by Hydraulic Fracturing," Ind. Water Eng., 32-132 (October 1970).

5. E. W. McDaniel, M. T. Morgan, J. G. Moore, H. E. Devaney, and L. R. Dole, Strontium Leachability of Hydrofracture Grouts for Sludge-Slurries, ORNL/TM-8198 (March 1982).

6. J. G. Moore, H. W. Godbee, A. H. Kibbey, and D. S. Joy, Development of Cementitious Grouts for the Incorporation of Radioactive Wastes. Part 1: Leach Studies, ORNL-4962, August 1975.

7. J. G. Moore, Development of Cementitious Grouts for the Incorporation of Radioactive Wastes. Part 2: Continuation of Cesium and Strontium Leach Studies, ORNL-5142, September 1976. 
8. T. M. Gilliam and J. A. Loflin, Leachability Studies of Hydrofracture Grouts, ORNL/TM9879, November 1986.

9. T. M. Gilliam, "Leach Testing of Hydrofracture Grouts Containing Hazardous Waste," J. Underground Injection Practices Council 1, 192-212 (1986).

10. T. L. Sams, ORNL, personal communications, 1987, 1988.

11. R. D. Spence, W. D. Bostick, E. W. McDaniel, T. M. Gilliam, J. L. Shoemaker, O. K. Tallent, I. L. Morgan, B. S. Evans-Brown, and K. E. Dodson, "Immobilization of Technetium in Blast Furnace Slag Grouts," paper presented at the 3rd International Conference on the Use of Fly Ash, Silica Fume, Slag, and Natural Pozzolans in Concrete, Trondheim, Norway, June 19-24, 1989.

12. T. M. Gilliam et al., "Solidification/Stabilization of Technetium in Cement-Based Grouts," J. Hazard Mater, 24, 189-197 (1990).

13. R. D. Spence et al., "Cementitious Stabilization of Chromium, Arsenic, and Selenium in a Cooling Tower Sludge," paper presented at the 88th Annual Meeting of the Air and Waste Management Association, San Antonio, Tex., June 18-23, 1995.

14. T. M. Gilliam, E. W. McDaniel, L. R. Dole, H. A. Friedman, J. A. Loflin, A. J. Mattus, I. L. Morgan, O. K. Tallent, and G. A. West, Summary Report on the Development of a Cement-Based Formula to Immobilize Hanford Facility Waste, ORNL/TM-10141, September 1987.

15. E. W. McDaniel, T. M. Gilliam, and L. R. Dole, "Recommended Major Grout Components, ORNL Milestone \#32, Project B-475, Transportable Grout Facility," Letter Report for the Hanford Grout Program (Apr. 15, 1984). 
16. W. de Laguna, et al., Engineering Development of Hydraulic Fracturing as a Method for Permanent Disposal of Radioactive Wastes, ORNL-4259, August 1968.

17. J. A. Stone, Evaluation of Concrete as a Matrix for Solidification of Savannah River Plant Waste, DP-1448, Savannah River Laboratory, Aiken, S.C., June 1977.

18. C. A. Langton, M. D. Dukes, and R. V. Simmons, "Cement-Based Waste Forms for Disposal of Savannah River Plant Low-Level Radioactive Salt Waste," DP-MS-83-71, CONF-831174-61, DE84 005197, Savannah River Laboratory, Aiken, S.C.; paper presented at the Materials Research Society Annual Meeting, Boston, Mass., Nov. 14-17, 1983.

19. H. C. Wolf, Large-Scale Demonstration of Disposal of Decontaminated Salt as Saltstone Part I: Construction, Loading, and Capping of Lysimeters, Savannah River Laboratory, Aiken, S.C., 1984.

20. D. W. Pepper, Transport of Nitrate from a Large Cement-Based Wasteform, DPST-85963, DE88 004271, Savannah River Laboratory, Aiken, S.C., 1986.

21. C. A. Langton, "Solidification of Low-Level Radioactive Waste at the Savannah River Site," WSRC-RP-89-288, DE89 013770, Westinghouse Savannah River Company, Savannah River Laboratory, Aiken, S.C.; paper presented at the NIST and NRC Workshop Cement Solidification of Low-Level Radioactive Waste, Gaithersburg, Md., May 31-June 12, 1989.

22. S. B. Clark and L. E. Wilhite, "Low-Level Liquid Waste Disposal at the Savannah River Site: A Large-Scale Demonstration of Saltstone," WSRC-MS-90-210, DE92 009907, Westinghouse Savannah River Co., Savannah River Laboratory, Aiken, S.C.; paper presented at Waste Management '91, Tucson, Ariz., Feb. 24-28, 1991. 
23. C. A. Langton and P. B. Wong, "Properties of Slag Concrete for Low-Level Waste Containment," WSRC-MS-91-073, DE92 013194, Westinghouse Savannah River Company, Aiken, S.C.; paper presented at the Spring Meeting of the American Concrete Institute, Mar. 17-21, 1991.

24. R. D. Petersen, A. J. Johnson, and K. G. Perter, Nitrate Salt Immobilization Process Development and Implementation, RFP-3919, DOE/TIC-4500 (Rev. 73), DE87 006190, Rockwell International, Rocky Flats Plant, Golden, Colo., 1986.

25. H. Zhou and P. Colombo, "Solidification of Radioactive Waste in a Cement/Lime Mixture," paper presented at Waste Management '84, Tucson, Ariz., 1984; pp. 163-68 in Proceedings.

26. D. F. Fischer and T. R. Johnson, Immobilization of IFR Salt Wastes in Mortar, CONF880903-45, DE89 003950, Argonne National Laboratory, Argonne, Ill., 1988.

27. C. W. McVay, J. R. Stimmel, and S. Marchetti, "WVNS Experience with Cement Solidification of Decontaminated Spent Fuel Waste," NUREG/CP-0103, West Valley Nuclear Services Co., Inc., West Valley, N.Y., published in Proceedings of Workshop on Cement Stabilization of Low-Level Radioactive Waste, 1989.

28. R. O. Lokken, J. W. Shade, and P. F. C. Martin, "Effect of Curing Temperature on the Properties of Cementitious Waste Forms," in Materials Research Society Proceedings, Vol. 176, Materials Research Society, 1990.

29. A. Bernard and J. C. Nomine, "Solidification de Concentrats d'Evaporateurs par Liants Hydrauliques," Colloque sur la Gestion des Dechets en Provenance des Reacteurs de Puissance sur le Site de la Centrale, Zurich, Mar. 26-30, 1979. 
30. P. Bouniol, Etude des Mecanismes de Piegeage du Cesium par des Melanges AdditifCiment pour le Conditionnement des Dechets Nitres, EUR 11097 FR, Sciences et Techniques Nucleaires, Commission des Communautes Europeenes, Batiment Jean Monnet, Luxembourg, 1987.

31. P. E. Bouniol, C. H. Peyre, A. J. Mattus, and W. W. Pitt, "Preliminary Results of the Immobilization of Highly-Salt-Ladened Concentrate in Cement-Based Grout: A Joint DOE/CEA Research Effort," CEA-CONF-9688, published in Proceedings of 1988 DOE Model Conference, October 3-7, 1988, Oak Ridge, Tenn., CONF-881054, Vol. 5.

32. R. Atabek, P. Bouniol, E. Revertegat, J. Oliver, P. Gegout, and M. Jorda, "Nuclear Waste Immobilization in Cement-Based Materials: Overview of French Studies," in Materials Research Society Symposium Proceedings, Vol. 176, Materials Research Society, 1990.

33. C. J. Kertesz, P. R. Chenavas, and G. M. Naud, "The Starting up of a Pilot Plant for Radioactive Incinerator Ash Conditioning—Results of Two Embedding Campaigns," paper presented at Waste Management '90, Tucson, Ariz., Feb. 25-Mar. 1, 1990.

34. M. H. de Pahissa, R. V. A. Gabarain, J. P. Campa, T. Ramallo, F. A. Gabarain, and L. C. Tramonti, "Saline Liquid Wastes-Solidification by Cementation," published in Spectrum '86, proceedings of the American Nuclear Society International Topical Meeting, Waste Management and Decontamination and Decommisioning, September 14-18, 1986, Niagara Falls, N.Y., CONF-860905, Vol. 1.

35. G. E. P. Box, and N. Draper, Empirical Model Building and Response Surface, Wiley, New York, 1987.

36. V. Fedorov, and P. Hackl, Model Oriented Design of Experiments, Springer, New York, 1997. 
37. V. Fedorov, Theory of Optimal Experiments, Academic Press, New York, 1972.

38. A. C. Atkinson, and A. N. Donev, Optimum Experimental Design, Clarendon Press, Oxford, 1992.

39. SAS/QC Software: "Design of Experiments Tools," SAS Institute, Inc., 1995.

40. B. Wheeler, ECHIP: Version 6.0 for Windows, ECHIP, Inc., Hockessin.

41. T. J. Mitchell, (a) "An Algorithm for Construction of D-optimal Experimental Design," (b) "Computer Construction of D-optimal 'First-Order' Designs," Technometrics 16, 203-10 (1974); Technometrics 16, 211-20 (1974).

42. G. A. F. Seber, Linear Regression Analysis, Wiley, New York, 1977. 
Table 1. Composition of standard MWFA surrogate sludges

\begin{tabular}{|c|c|c|}
\hline Constituent & $\begin{array}{c}\text { High-chloride }^{a} \\
\text { sludge } \\
\text { (wt \%) }\end{array}$ & $\begin{array}{c}\text { High-nitrate }^{b} \\
\text { sludge } \\
\text { (wt \%) } \\
\end{array}$ \\
\hline $\mathrm{Fe}(\mathrm{OH})_{3}$ as $\mathrm{Fe}_{2} \mathrm{O}_{3}$ & 12.75 & 6.00 \\
\hline $\mathrm{Al}(\mathrm{OH})_{3}$ & 8.50 & 4.00 \\
\hline $\mathrm{Na}_{3} \mathrm{PO}_{4}$ & 4.25 & 2.00 \\
\hline $\mathrm{Mg}(\mathrm{OH})_{2}$ & 8.50 & 4.00 \\
\hline MicroCel E & 17.00 & 8.00 \\
\hline Portland Cement (Type II) & 4.25 & 2.00 \\
\hline $\mathrm{H}_{2} \mathrm{O}$ & 29.75 & 14.00 \\
\hline \multicolumn{3}{|c|}{ Salts } \\
\hline $\mathrm{NaCl}$ & 10.00 & 0.00 \\
\hline $\mathrm{CaSO}_{4}$ & 5.00 & 0.00 \\
\hline $\mathrm{NaNO}_{3}$ & 0.00 & 60.00 \\
\hline Total & 100.00 & 100.00 \\
\hline \multicolumn{3}{|c|}{ Contaminants (mg/kg) } \\
\hline \multicolumn{3}{|l|}{ Toxic metal oxide ${ }^{c}$} \\
\hline $\mathrm{PbO}$ & 1000 & 1000 \\
\hline $\mathrm{CrO}_{3}$ & 1000 & 1000 \\
\hline $\mathrm{HgO}$ & 1000 & 1000 \\
\hline $\mathrm{CdO}$ & 1000 & 1000 \\
\hline $\mathrm{NiO}$ & 1000 & 1000 \\
\hline Trichloroethylene $^{d}$ & 1000 & 1000 \\
\hline
\end{tabular}

${ }^{a}$ The first six constituents, $\mathrm{Fe}(\mathrm{OH})_{3}$ through water; were selected on the basis of a representative sludge. The weight percentage of these constituents without the salts and/or organics are 15,10 , $5,10,20,5$, and 35 , respectively.

${ }^{b}$ The nonsalt portion of the nitrate waste is identical to the nonhazardous sludge used in column 1 .

'The toxic metals are to be added as oxides. Use all five, each at the $1000-\mathrm{mg} / \mathrm{kg}$ concentration, referenced to the final waste (not including the stabilization agent). Indicate if they are added as another salt (e.g., as the nitrate).

${ }^{d}$ Trichloroethylene is assumed to be the RCRA hazardous organic contaminant. 
Table 2. Initial statistical design used in laboratory testing after broadening constraints to incorporate MWFA surrogate and using < $70 \%$ nitrate

\begin{tabular}{|c|c|c|c|c|c|c|c|c|c|c|c|}
\hline \multirow{2}{*}{$\begin{array}{c}\text { Randomized } \\
\text { order }\end{array}$} & \multirow[b]{2}{*}{ Trial no. } & \multicolumn{5}{|c|}{ Dry blend/waste solids ratio } & \multicolumn{4}{|c|}{ Composition of waste solids (mass fraction) } & \multirow[b]{2}{*}{$\begin{array}{c}\text { Water } \\
\mathrm{x}_{8} \\
\end{array}$} \\
\hline & & $\begin{array}{c}\text { Cement, } \\
x_{1}\end{array}$ & $\begin{array}{c}\text { Slag, } \\
x_{2}\end{array}$ & $\begin{array}{c}\text { Clay, } \\
\mathrm{x}_{3} \\
\end{array}$ & $\begin{array}{c}\text { Fly ash, } \\
\mathrm{x}_{\alpha}\end{array}$ & Total & $\begin{array}{c}\text { Chloride, } \\
x_{5}\end{array}$ & $\begin{array}{c}\text { Sulfate, } \\
\mathrm{x}_{\kappa}\end{array}$ & $\begin{array}{c}\text { Nitrate, } \\
x_{7}\end{array}$ & Other solids & \\
\hline 1 & Center 1 & 0.15 & 1.34 & 0.21 & 0.43 & 2.13 & 0.00 & 0.00 & 0.60 & 0.40 & -1 \\
\hline 2 & Center 2 & 0.15 & 1.34 & 0.21 & 0.43 & 2.13 & 0.10 & 0.05 & 0.00 & 0.85 & 1 \\
\hline 3 & Center 1 & 0.15 & 1.34 & 0.21 & 0.43 & 2.13 & 0.00 & 0.00 & 0.60 & 0.40 & -1 \\
\hline 4 & Center 2 & 0.15 & 1.34 & 0.21 & 0.43 & 2.13 & 0.10 & 0.05 & 0.00 & 0.85 & 1 \\
\hline 5 & 3 & 2.70 & 0.00 & 0.00 & 0.90 & 3.60 & 0.30 & 0.00 & 0.00 & 0.70 & -1 \\
\hline 6 & 8 & 0.06 & 0.64 & 0.40 & 0.90 & 2.00 & 0.30 & 0.00 & 0.40 & 0.30 & 1 \\
\hline 7 & 18 & 0.70 & 0.00 & 0.00 & 0.90 & 1.60 & 0.00 & 0.00 & 0.10 & 0.90 & 1 \\
\hline 8 & 5 & 0.25 & 2.45 & 0.00 & 0.90 & 3.60 & 0.00 & 0.00 & 0.10 & 0.90 & -1 \\
\hline 9 & 14 & 2.70 & 0.00 & 0.00 & 0.90 & 3.60 & 0.15 & 0.15 & 0.40 & 0.30 & 1 \\
\hline 10 & 31 & 2.70 & 0.00 & 0.00 & 0.00 & 2.70 & 0.00 & 0.00 & 0.70 & 0.30 & 1 \\
\hline 11 & 1 & 2.70 & 0.00 & 0.40 & 0.00 & 3.10 & 0.00 & 0.00 & 0.70 & 0.30 & 1 \\
\hline 12 & 11 & 0.06 & 0.64 & 0.40 & 0.00 & 1.10 & 0.15 & 0.15 & 0.00 & 0.70 & -1 \\
\hline 13 & 7 & 0.06 & 0.64 & 0.00 & 0.00 & 0.70 & 0.00 & 0.30 & 0.40 & 0.30 & 1 \\
\hline 14 & 4 & 2.70 & 0.00 & 0.00 & 0.90 & 3.60 & 0.00 & 0.30 & 0.00 & 0.70 & -1 \\
\hline 15 & 2 & 2.70 & 0.00 & 0.40 & 0.00 & 3.10 & 0.00 & 0.00 & 0.10 & 0.90 & 1 \\
\hline 16 & 28 & 0.25 & 2.45 & 0.40 & 0.90 & 4.00 & 0.15 & 0.15 & 0.40 & 0.30 & -1 \\
\hline 17 & 16 & 2.70 & 0.00 & 0.40 & 0.00 & 3.10 & 0.00 & 0.30 & 0.40 & 0.30 & -1 \\
\hline 18 & 7 & 0.06 & 0.64 & 0.00 & 0.00 & 0.70 & 0.00 & 0.30 & 0.40 & 0.30 & 1 \\
\hline 19 & 19 & 0.25 & 2.45 & 0.00 & 0.90 & 3.60 & 0.00 & 0.30 & 0.40 & 0.30 & 1 \\
\hline 20 & 1 & 2.70 & 0.00 & 0.40 & 0.00 & 3.10 & 0.00 & 0.00 & 0.70 & 0.30 & 1 \\
\hline 21 & 26 & 0.06 & 0.64 & 0.00 & 0.00 & 0.70 & 0.00 & 0.00 & 0.10 & 0.90 & -1 \\
\hline 22 & 11 & 0.06 & 0.64 & 0.40 & 0.00 & 1.10 & 0.15 & 0.15 & 0.00 & 0.70 & -1 \\
\hline 23 & 4 & 2.70 & 0.00 & 0.00 & 0.90 & 3.60 & 0.00 & 0.30 & 0.00 & 0.70 & -1 \\
\hline 24 & 3 & 2.70 & 0.00 & 0.00 & 0.90 & 3.60 & 0.30 & 0.00 & 0.00 & 0.70 & -1 \\
\hline 25 & 2 & 2.70 & 0.00 & 0.40 & 0.00 & 3.10 & 0.00 & 0.00 & 0.10 & 0.90 & 1 \\
\hline 26 & 16 & 2.70 & 0.00 & 0.40 & 0.00 & 3.10 & 0.00 & 0.30 & 0.40 & 0.30 & -1 \\
\hline 27 & 6 & 0.06 & 0.64 & 0.40 & 0.00 & 1.10 & 0.30 & 0.00 & 0.40 & 0.30 & -1 \\
\hline 28 & 25 & 0.25 & 2.45 & 0.00 & 0.00 & 2.70 & 0.30 & 0.00 & 0.40 & 0.30 & 1 \\
\hline 29 & 36 & 0.25 & 2.45 & 0.40 & 0.00 & 3.10 & 0.15 & 0.15 & 0.40 & 0.30 & -1 \\
\hline 30 & 24 & 0.70 & 0.00 & 0.00 & 0.90 & 1.60 & 0.00 & 0.00 & 0.70 & 0.30 & 1 \\
\hline 31 & 9 & 0.70 & 0.00 & 0.40 & 0.90 & 2.00 & 0.00 & 0.30 & 0.40 & 0.30 & -1 \\
\hline 32 & 30 & 2.70 & 0.00 & 0.40 & 0.90 & 4.00 & 0.15 & 0.15 & 0.00 & 0.70 & 1 \\
\hline
\end{tabular}


Table 2. Initial statistical design used in laboratory testing after broadening constraints to incorporate MWFA surrogate and using < $70 \%$ nitrate (continued)

\begin{tabular}{|c|c|c|c|c|c|c|c|c|c|c|c|}
\hline \multirow[b]{2}{*}{$\begin{array}{c}\text { Randomized } \\
\text { order }\end{array}$} & \multirow[b]{2}{*}{ Trial no. } & \multicolumn{5}{|c|}{ Dry blend/waste solids ratio } & \multicolumn{4}{|c|}{ Composition of waste solids (mass fraction) } & \multirow[b]{2}{*}{$\begin{array}{c}\text { Water } \\
x_{8}\end{array}$} \\
\hline & & $\begin{array}{c}\text { Cement, } \\
x_{1}\end{array}$ & $\begin{array}{c}\text { Slag, } \\
x_{2}\end{array}$ & $\begin{array}{c}\text { Clay, } \\
x_{3}\end{array}$ & $\begin{array}{c}\text { Fly ash, } \\
x_{4}\end{array}$ & Total & $\begin{array}{c}\text { Chloride, } \\
\mathrm{x}_{5}\end{array}$ & $\begin{array}{c}\text { Sulfate, } \\
x_{6}\end{array}$ & $\begin{array}{c}\text { Nitrate, } \\
\mathrm{x}_{7}\end{array}$ & Other solids & \\
\hline 33 & 13 & 0.25 & 2.45 & 0.40 & 0.90 & 4.00 & 0.00 & 0.30 & 0.00 & 0.70 & 1 \\
\hline 34 & 4 & 2.70 & 0.00 & 0.00 & 0.90 & 3.60 & 0.00 & 0.30 & 0.00 & 0.70 & -1 \\
\hline 35 & 8 & 0.06 & 0.64 & 0.40 & 0.90 & 2.00 & 0.30 & 0.00 & 0.40 & 0.30 & 1 \\
\hline 36 & 29 & 2.70 & 0.00 & 0.00 & 0.90 & 3.60 & 0.30 & 0.00 & 0.40 & 0.30 & -1 \\
\hline 37 & 34 & 0.25 & 2.45 & 0.40 & 0.90 & 4.00 & 0.00 & 0.00 & 0.70 & 0.30 & -1 \\
\hline 38 & 2 & 2.70 & 0.00 & 0.40 & 0.00 & 3.10 & 0.00 & 0.00 & 0.10 & 0.90 & 1 \\
\hline 39 & 12 & 0.06 & 0.64 & 0.00 & 0.00 & 0.70 & 0.00 & 0.00 & 0.70 & 0.30 & -1 \\
\hline 40 & 21 & 0.25 & 2.45 & 0.00 & 0.00 & 2.70 & 0.30 & 0.00 & 0.00 & 0.70 & -1 \\
\hline 41 & 10 & 0.25 & 2.45 & 0.40 & 0.00 & 3.10 & 0.30 & 0.00 & 0.00 & 0.70 & 1 \\
\hline 42 & 9 & 0.70 & 0.00 & 0.40 & 0.90 & 2.00 & 0.00 & 0.30 & 0.40 & 0.30 & -1 \\
\hline 43 & 22 & 0.70 & 0.00 & 0.00 & 0.00 & 0.70 & 0.15 & 0.15 & 0.00 & 0.70 & 1 \\
\hline 44 & 6 & 0.06 & 0.64 & 0.40 & 0.00 & 1.10 & 0.30 & 0.00 & 0.40 & 0.30 & -1 \\
\hline 45 & 15 & 2.70 & 0.00 & 0.00 & 0.00 & 2.70 & 0.30 & 0.00 & 0.40 & 0.30 & -1 \\
\hline 46 & 10 & 0.25 & 2.45 & 0.40 & 0.00 & 3.10 & 0.30 & 0.00 & 0.00 & 0.70 & 1 \\
\hline 47 & 23 & 0.70 & 0.00 & 0.40 & 0.00 & 1.10 & 0.00 & 0.30 & 0.00 & 0.70 & -1 \\
\hline 48 & 17 & 0.25 & 2.45 & 0.00 & 0.00 & 2.70 & 0.00 & 0.30 & 0.00 & 0.70 & 1 \\
\hline 49 & 35 & 0.25 & 2.45 & 0.40 & 0.90 & 4.00 & 0.00 & 0.00 & 0.10 & 0.90 & -1 \\
\hline 50 & 20 & 0.70 & 0.00 & 0.40 & 0.90 & 2.00 & 0.30 & 0.00 & 0.00 & 0.70 & 1 \\
\hline 51 & 5 & 0.25 & 2.45 & 0.00 & 0.90 & 3.60 & 0.00 & 0.00 & 0.10 & 0.90 & -1 \\
\hline
\end{tabular}


Table 3. Total concentrations measured in the ECM sludge samples

\begin{tabular}{|c|c|c|c|c|c|c|c|c|c|c|}
\hline \multirow[t]{2}{*}{ Bucket } & \multirow[t]{2}{*}{ Sample } & \multirow{2}{*}{$\begin{array}{c}\text { Moisture } \\
\text { (wt \%) }\end{array}$} & \multicolumn{8}{|c|}{ Concentration $(\mathrm{mg} / \mathrm{kg})$} \\
\hline & & & Cadmium & Chloride & Chromium & Mercury & Nickel & Nitrate & Lead & Sulfate \\
\hline \multirow{4}{*}{1} & 1 & 62.30 & 2.29 & $<120$ & 114 & 0.219 & 6.66 & 142,000 & $<2.98$ & $<240$ \\
\hline & 2 & 63.30 & $<1.88$ & $<120$ & 110 & $<.188$ & 6.47 & 143,000 & $<2.81$ & $<240$ \\
\hline & 3 & 63.90 & $<1.87$ & $<125$ & 112 & $<.187$ & 6.91 & 142,000 & $<2.80$ & $<249$ \\
\hline & 4 & 64.30 & $<1.94$ & $<125$ & 115 & 0.196 & 6.51 & 141,000 & $<2.91$ & $<240$ \\
\hline \multirow{6}{*}{2} & 5 & 64.30 & $<1.94$ & $<120$ & 114 & 0.195 & 7.46 & 148,000 & $<2.91$ & $<241$ \\
\hline & 1 & 62.20 & $<4.07$ & $\mathrm{~N} / \mathrm{A}$ & 134 & 0.206 & 6.92 & 140,000 & $<8.14$ & $N / A^{n}$ \\
\hline & 2 & 61.70 & $<4.10$ & N/A & 138 & $<.205$ & 6.56 & 142,000 & $<8.20$ & N/A \\
\hline & 3 & 61.50 & $<3.83$ & $\mathrm{~N} / \mathrm{A}$ & 135 & $<.192$ & 7.28 & 145,000 & $<7.66$ & $\mathrm{~N} / \mathrm{A}$ \\
\hline & 4 & 62.00 & $<3.96$ & $\mathrm{~N} / \mathrm{A}$ & 133 & $<.198$ & 7.73 & 143,000 & $<7.93$ & $\mathrm{~N} / \mathrm{A}$ \\
\hline & 5 & 61.90 & $<4.10$ & N/A & 135 & $<.205$ & 11.1 & 148,000 & $<8.20$ & N/A \\
\hline \multirow{4}{*}{3} & 1 & 64.20 & $<1.95$ & $<118$ & 93.5 & $<.195$ & 6.16 & 134,000 & $<2.93$ & $<236$ \\
\hline & 2 & 60.60 & $<1.99$ & $<122$ & 90.1 & $<.199$ & 5.66 & 143,000 & $<2.98$ & $<243$ \\
\hline & 3 & 64.40 & $<1.85$ & $<122$ & 91.7 & $<.185$ & 6.12 & 135,000 & $<2.78$ & $<243$ \\
\hline & 4 & 67.10 & $<2.00$ & $<125$ & 94.3 & $<.200$ & 6.89 & 140,000 & $<3.00$ & $<250$ \\
\hline \multirow{6}{*}{4} & 5 & 61.90 & $<1.95$ & $<121$ & 97.9 & $<.195$ & 7.5 & 136,000 & $<2.92$ & $<242$ \\
\hline & 1 & 63.70 & $<1.84$ & $<122$ & 96.8 & $<.184$ & 7.73 & 142,000 & $<2.76$ & $<243$ \\
\hline & 2 & 64.50 & 1.91 & $<125$ & 91.5 & $<.182$ & 6.83 & 144,000 & $<2.73$ & $<250$ \\
\hline & 3 & 64.70 & $<1.93$ & $<121$ & 94.4 & $<.193$ & 6.87 & 138,000 & $<2.90$ & $<241$ \\
\hline & 4 & 63.70 & $<1.96$ & $<122$ & 96.5 & $<.196$ & 7.86 & 138,000 & $<2.95$ & $<245$ \\
\hline & 5 & 64.70 & $<1.96$ & $<119$ & 104 & $<.196$ & 7.44 & 140,000 & 3.82 & $<238$ \\
\hline
\end{tabular}

"N/A = Not analyzed. 
Table 4. Average, standard deviation, and percentage RSD of the significant total concentrations measured in the ECM sludge samples and TCLP extract concentrations of bucket composite samples

\begin{tabular}{|c|c|c|c|c|c|c|c|}
\hline \multirow[b]{2}{*}{ Bucket } & \multirow[b]{2}{*}{ Sample } & \multirow{2}{*}{$\begin{array}{l}\text { Moisture } \\
\text { (wt \%) }\end{array}$} & \multicolumn{3}{|c|}{$\begin{array}{l}\text { Total sludge concentration } \\
\qquad(\mathrm{mg} / \mathrm{kg})\end{array}$} & \multicolumn{2}{|c|}{$\begin{array}{l}\text { TCLP extract concentration } \\
(\mathrm{mg} / \mathrm{L})\end{array}$} \\
\hline & & & Chromium & Nickel & Nitrate & Chromium & Nickel \\
\hline \multirow{3}{*}{1} & Average & $63.62^{a}$ & 113 & 6.80 & 143,200 & 0.09 & 0.26 \\
\hline & Std. dev. & 0.75 & 2 & 0.36 & 2,482 & & \\
\hline & $\%$ RSD & $1.19 \%$ & $1.58 \%$ & $5.34 \%$ & $1.73 \%$ & & \\
\hline \multirow{3}{*}{2} & Average & $61.86^{b}$ & 135 & 7.92 & 143,600 & 0.32 & 0.26 \\
\hline & Std. Dev. & 0.24 & 2 & 1.64 & 2,728 & & \\
\hline & $\%$ RSD & $0.39 \%$ & $1.24 \%$ & $20.68 \%$ & $1.90 \%$ & & \\
\hline \multirow{3}{*}{3} & Average & $63.64^{c}$ & 94 & 6.47 & 137,600 & $<0.03$ & 0.25 \\
\hline & Std. Dev. & 2.24 & 3 & 0.65 & 3,382 & & \\
\hline & $\%$ RSD & $3.52 \%$ & $2.82 \%$ & $10.05 \%$ & $2.46 \%$ & & \\
\hline \multirow{3}{*}{4} & Average & $64.26^{d}$ & 97 & 7.35 & 140,400 & 0.31 & 0.24 \\
\hline & Std. Dev. & 0.46 & 4 & 0.43 & 2,332 & & \\
\hline & $\%$ RSD & $0.72 \%$ & $4.28 \%$ & $5.82 \%$ & $1.66 \%$ & & \\
\hline
\end{tabular}

${ }^{a}$ Bucket dried to a moisture content of $57.5 \mathrm{wt} \%$ with corresponding increase in concentration for other components.

${ }^{b}$ Bucket dried to a moisture content of $57.1 \mathrm{wt} \%$ with corresponding increase in concentration for other components.

c Bucket dried to a moisture content of $43.7 \mathrm{wt} \%$ with corresponding increase in concentration for other components.

${ }^{d}$ Bucket dried to a moisture content of $57.7 \mathrm{wt} \%$ with corresponding increase in concentration for other components. 
Table 5. Grout compositions for the initial design

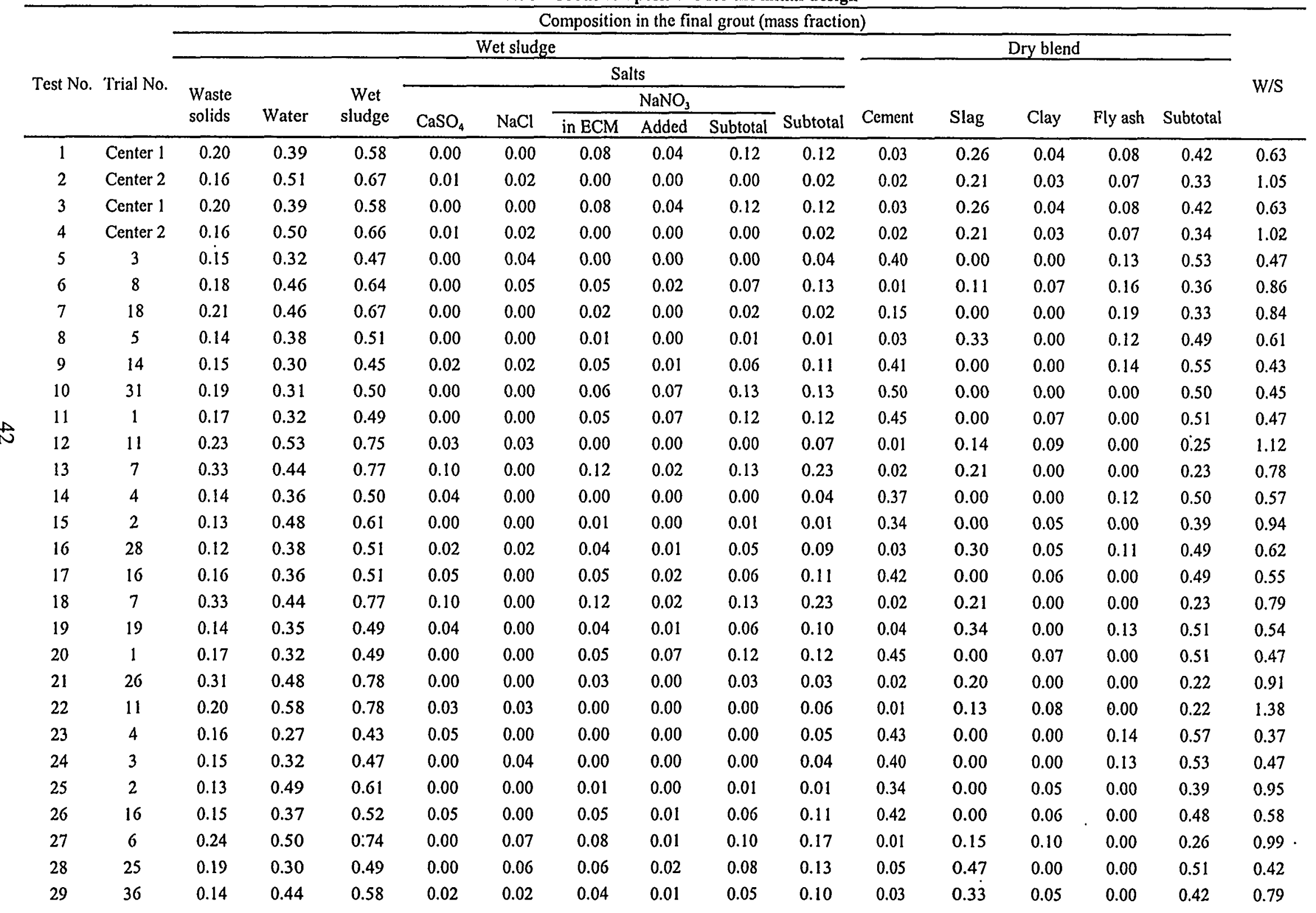


Table 5. Grout compositions for the initial design (continued)

\begin{tabular}{|c|c|c|c|c|c|c|c|c|c|c|c|c|c|c|c|c|}
\hline \multirow{5}{*}{ Test No. } & \multirow{5}{*}{ Trial No. } & \multicolumn{14}{|c|}{ Composition in the final grout (mass fraction) } & \multirow{5}{*}{$W / S$} \\
\hline & & \multicolumn{9}{|c|}{ Wet sludge } & \multicolumn{5}{|c|}{ Dry blend } & \\
\hline & & \multirow{3}{*}{$\begin{array}{l}\text { Waste } \\
\text { solids }\end{array}$} & \multirow{3}{*}{ Water } & \multirow{3}{*}{$\begin{array}{c}\text { Wet } \\
\text { sludge }\end{array}$} & \multirow[b]{3}{*}{$\mathrm{CaSO}_{4}$} & \multicolumn{4}{|c|}{ Salts } & \multirow[b]{3}{*}{ Subtotal } & \multirow{3}{*}{ Cement } & \multirow{3}{*}{ Slag } & \multirow{3}{*}{ Clay } & \multirow{3}{*}{ Fly ash } & \multirow{3}{*}{ Subtotal } & \\
\hline & & & & & & & & $\mathrm{NaNO}_{3}$ & & & & & & & & \\
\hline & & & & & & $\mathrm{NaCl}$ & in ECM & Added & Subtotal & & & & & & & \\
\hline 30 & 24 & 0.24 & 0.39 & 0.62 & 0.00 & 0.00 & 0.07 & 0.09 & 0.17 & 0.17 & 0.17 & 0.00 & 0.00 & 0.21 & 0.38 & 0.63 \\
\hline 31 & 9 & 0.16 & 0.51 & 0.67 & 0.05 & 0.00 & 0.05 & 0.02 & 0.07 & 0.11 & 0.11 & 0.00 & 0.07 & 0.15 & 0.33 & 1.03 \\
\hline 32 & 30 & 0.11 & 0.45 & 0.56 & 0.02 & 0.02 & 0.00 & 0.00 & 0.00 & 0.03 & 0.29 & 0.00 & 0.04 & 0.10 & 0.44 & 0.83 \\
\hline 33 & 13 & 0.11 & 0.45 & 0.56 & 0.03 & 0.00 & 0.00 & 0.00 & 0.00 & 0.03 & 0.03 & 0.27 & 0.04 & 0.10 & 0.44 & 0.82 \\
\hline 34 & 4 & 0.13 & 0.41 & 0.54 & 0.04 & 0.00 & 0.00 & 0.00 & 0.00 & 0.04 & 0.34 & 0.00 & 0.00 & 0.11 & 0.46 & 0.71 \\
\hline 35 & 8 & 0.17 & 0.48 & 0.65 & 0.00 & 0.05 & 0.05 & 0.02 & 0.07 & 0.12 & 0.01 & 0.11 & 0.07 & 0.16 & 0.35 & 0.92 \\
\hline 36 & 29 & 0.16 & 0.25 & 0.41 & 0.00 & 0.05 & 0.05 & 0.02 & 0.07 & 0.11 & 0.44 & 0.00 & 0.00 & 0.15 & 0.59 & 0.33 \\
\hline 37 & 34 & 0.13 & 0.37 & 0.49 & 0.00 & 0.00 & 0.04 & 0.05 & 0.09 & 0.09 & 0.03 & 0.31 & 0.05 & 0.11 & 0.51 & 0.58 \\
\hline 38 & 2 & 0.12 & 0.50 & 0.63 & 0.00 & 0.00 & 0.01 & 0.00 & 0.01 & 0.01 & 0.33 & 0.00 & 0.05 & 0.00 & 0.37 & 1.02 \\
\hline 39 & 12 & 0.39 & 0.34 & 0.73 & 0.00 & 0.00 & 0.14 & 0.13 & 0.27 & 0.27 & 0.02 & 0.25 & 0.00 & 0.00 & 0.27 & 0.52 \\
\hline 40 & 21 & 0.19 & 0.29 & 0.48 & 0.00 & 0.06 & 0.00 & 0.00 & 0.00 & 0.06 & 0.05 & 0.47 & 0.00 & 0.00 & 0.52 & 0.40 \\
\hline 41 & 10 & 0.12 & 0.49 & 0.62 & 0.00 & 0.04 & 0.00 & 0.00 & 0.00 & 0.04 & 0.03 & 0.30 & 0.05 & 0.00 & 0.38 & 0.97 \\
\hline 42 & 9 & 0.17 & 0.48 & 0.66 & 0.05 & 0.00 & 0.05 & 0.02 & 0.07 & 0.12 & 0.12 & 0.00 & 0.07 & 0.15 & 0.34 & 0.93 \\
\hline 43 & 22 & 0.30 & 0.49 & 0.79 & 0.05 & 0.04 & 0.00 & 0.00 & 0.00 & 0.09 & 0.21 & 0.00 & 0.00 & 0.00 & 0.21 & 0.96 \\
\hline 44 & 6 & 0.24 & 0.50 & 0.74 & 0.00 & 0.07 & 0.08 & 0.01 & 0.10 & 0.17 & 0.01 & 0.15 & 0.10 & 0.00 & 0.26 & 0.99 \\
\hline 45 & 15 & 0.19 & 0.28 & 0.48 & 0.00 & 0.06 & 0.06 & 0.02 & 0.08 & 0.14 & 0.52 & 0.00 & 0.00 & 0.00 & 0.52 & 0.40 \\
\hline 46 & 10 & 0.12 & 0.49 & 0.62 & 0.00 & 0.04 & 0.00 & 0.00 & 0.00 & 0.04 & 0.03 & 0.30 & 0.05 & 0.00 & 0.38 & 0.97 \\
\hline 47 & 23 & 0.19 & 0.61 & 0.80 & 0.06 & 0.00 & 0.00 & 0.00 & 0.00 & 0.06 & 0.13 & 0.00 & 0.07 & 0.00 & 0.20 & 1.55 \\
\hline 48 & 17 & 0.15 & 0.44 & 0.60 & 0.05 & 0.00 & 0.00 & 0.00 & 0.00 & 0.05 & 0.04 & 0.37 & 0.00 & 0.00 & 0.40 & 0.80 \\
\hline 49 & 35 & 0.11 & 0.44 & 0.55 & 0.00 & 0.00 & 0.01 & 0.00 & 0.01 & 0.01 & 0.03 & 0.27 & 0.04 & 0.10 & 0.45 & 0.79 \\
\hline 50 & 20 & 0.15 & 0.56 & 0.71 & 0.00 & 0.04 & 0.00 & 0.00 & 0.00 & 0.04 & 0.10 & 0.00 & 0.06 & 0.13 & 0.29 & 1.28 \\
\hline 51 & 5 & 0.13 & 0.39 & 0.52 & 0.00 & 0.00 & 0.01 & 0.00 & 0.01 & 0.01 & 0.03 & 0.33 & 0.00 & 0.12 & 0.48 & 0.64 \\
\hline
\end{tabular}


Table 6. Additional data for the wet sludge makcup for the initial design

\begin{tabular}{|c|c|c|c|c|c|c|c|c|c|c|c|c|c|}
\hline \multirow[b]{3}{*}{ Test no. } & \multirow{3}{*}{ Trial no. } & \multicolumn{7}{|c|}{ Composition in the final grout (mass fraction) } & \multicolumn{5}{|c|}{ RCRA compound concentration in waste solids $(\mathrm{mg} / \mathrm{kg})$} \\
\hline & & \multirow{2}{*}{$\begin{array}{c}\text { Wet ECM } \\
\text { sludge }\end{array}$} & \multicolumn{6}{|c|}{ MWFA other solids } & \multirow[b]{2}{*}{$\mathrm{PbO}$} & \multirow[b]{2}{*}{$\mathrm{CrO}_{3}$} & \multirow[b]{2}{*}{$\mathrm{HgO}$} & \multirow[b]{2}{*}{$\mathrm{CdO}$} & \multirow[b]{2}{*}{$\mathrm{NiO}$} \\
\hline & & & $\mathrm{Fe}_{2} \mathrm{O}_{3}$ & $\mathrm{Al}(\mathrm{OH})_{3}$ & $\mathrm{Na}_{3} \mathrm{PO}_{4} \cdot 12 \mathrm{H}_{2} \mathrm{O}$ & $\mathrm{Mg}(\mathrm{OH})_{2}$ & $\mathrm{CaSiO}_{3}$ & Subtotal & & & & & \\
\hline 1 & Center 1 & 0.37 & 0.00 & 0.00 & 0.00 & 0.00 & 0.00 & 0.00 & 993 & 690 & 1333 & 209 & 447 \\
\hline 2 & Center 2 & 0.00 & 0.03 & 0.02 & 0.01 & 0.02 & 0.04 & 0.13 & 1003 & 144 & 1340 & 215 & 433 \\
\hline 3 & Center 1 & 0.37 & 0.00 & 0.00 & 0.00 & 0.00 & 0.00 & 0.00 & 1000 & 687 & 1335 & 209 & 448 \\
\hline 4 & Center 2 & 0.00 & 0.03 & 0.02 & 0.01 & 0.02 & 0.04 & 0.13 & 996 & 147 & 1328 & 211 & 431 \\
\hline 5 & 3 & 0.00 & 0.03 & 0.02 & 0.01 & 0.02 & 0.03 & 0.10 & 1030 & 2678 & 0 & 0 & 894 \\
\hline 6 & 8 & 0.25 & 0.00 & 0.00 & 0.00 & 0.00 & 0.00 & 0.00 & 998 & 465 & 532 & 401 & 911 \\
\hline 7 & 18 & 0.10 & 0.04 & 0.03 & 0.01 & 0.03 & 0.06 & 0.17 & 996 & $826^{\circ}$ & 0 & 0 & 906 \\
\hline 8 & 5 & 0.06 & 0.03 & 0.02 & 0.01 & 0.02 & 0.04 & 0.11 & 1003 & 380 & 2440 & 0 & 896 \\
\hline 9 & 14 & 0.22 & 0.00 & 0.00 & 0.00 & 0.00 & 0.00 & 0.00 & 986 & 3104 & 0 & 0 & 905 \\
\hline 10 & 31 & 0.26 & 0.00 & 0.00 & 0.00 & 0.00 & 0.00 & 0.00 & 999 & 3090 & 0 & 0 & 16 \\
\hline 11 & 1 & 0.24 & 0.00 & 0.00 & 0.00 & 0.00 & 0.00 & 0.00 & 996 & 3098 & 0 & 399 & 16 \\
\hline 12 & 11 & 0.00 & 0.04 & 0.03 & 0.01 & 0.03 & 0.05 & 0.16 & 1002 & 73 & 641 & 408 & 0 \\
\hline 13 & 7 & 0.50 & 0.00 & 0.00 & 0.00 & 0.00 & 0.00 & 0.00 & 998 & 449 & 642 & 0 & 16 \\
\hline 14 & 4 & 0.00 & 0.02 & 0.02 & 0.01 & 0.02 & 0.03 & 0.10 & 982 & 2631 & 0 & 0 & 887 \\
\hline 15 & 2 & 0.06 & 0.03 & 0.02 & 0.01 & 0.02 & 0.03 & 0.10 & 988 & 2815 & 0 & 404 & 5 \\
\hline 16 & 28 & 0.17 & 0.00 & 0.00 & 0.00 & 0.00 & 0.00 & 0.00 & 1001 & 658 & 2435 & 406 & 905 \\
\hline 17 & 16 & 0.22 & 0.00 & 0.00 & 0.00 & 0.00 & 0.00 & 0.00 & 993 & 3075 & 0 & 399 & 16 \\
\hline 18 & 7 & 0.50 & 0.00 & 0.00 & 0.00 & 0.00 & 0.00 & 0.00 & 998 & 448 & 639 & 0 & 16 \\
\hline 19 & 19 & 0.20 & 0.00 & 0.00 & 0.00 & 0.00 & 0.00 & 0.00 & 990 & 657 & 2415 & 0 & 903 \\
\hline 20 & 1 & 0.23 & 0.00 & 0.00 & 0.00 & 0.00 & 0.00 & 0.00 & 996 & 3095 & 0 & 395 & 16 \\
\hline 21 & 26 & 0.14 & 0.06 & 0.04 & 0.02 & 0.04 & 0.08 & 0.25 & 1014 & 193 & 638 & 0 & 5 \\
\hline 22 & 11 & 0.00 & 0.04 & 0.02 & 0.01 & 0.02 & 0.05 & 0.14 & 991 & 59 & 633 & 400 & 0 \\
\hline 23 & 4 & 0.00 & 0.03 & 0.02 & 0.01 & 0.02 & 0.04 & 0.11 & 1004 & 2707 & 0 & 0 & 909 \\
\hline 24 & 3 & 0.00 & 0.03 & 0.02 & 0.01 & 0.02 & 0.03 & 0.10 & 993 & 2698 & 0 & 0 & 898 \\
\hline 25 & 2 & 0.06 & 0.03 & 0.02 & 0.01 & 0.02 & 0.03 & 0.10 & 996 & 2822 & 0 & 397 & 5 \\
\hline 26 & 16 & 0.22 & 0.00 & 0.00 & 0.00 & 0.00 & 0.00 & 0.00 & 999 & 3106 & 0 & 403 & 16 \\
\hline
\end{tabular}


Table 6. Additional data for the wet sludge makeup for the initial design (continued)

\begin{tabular}{|c|c|c|c|c|c|c|c|c|c|c|c|c|c|}
\hline \multirow[b]{3}{*}{ Test no. } & \multirow[b]{3}{*}{ Trial no. } & \multicolumn{7}{|c|}{ Composition in the final grout (mass fraction) } & \multicolumn{5}{|c|}{ RCRA compound concentration in waste solids ( $\mathrm{mg} / \mathrm{kg}$ ) } \\
\hline & & \multirow{2}{*}{$\begin{array}{c}\text { Wet ECM } \\
\text { sludge }\end{array}$} & \multicolumn{6}{|c|}{ MWFA other solids } & \multirow[b]{2}{*}{$\mathrm{PbO}$} & \multirow[b]{2}{*}{$\mathrm{CrO}_{3}$} & \multirow[b]{2}{*}{$\mathrm{HgO}$} & \multirow[b]{2}{*}{$\mathrm{CdO}$} & \multirow[b]{2}{*}{$\mathrm{NiO}$} \\
\hline & & & $\mathrm{Fe}_{2} \mathrm{O}_{3}$ & $\mathrm{Al}(\mathrm{OH})_{3}$ & $\mathrm{Na}_{3} \mathrm{PO}_{4} \cdot 12 \mathrm{H}_{2} \mathrm{O}$ & $\mathrm{Mg}(\mathrm{OH})_{2}$ & $\mathrm{CaSiO}_{3}$ & Subtotal & & & & & \\
\hline 27 & 6 & 0.37 & 0.00 & 0.00 & 0.00 & 0.00 & 0.00 & 0.00 & 997 & 448 & 638 & 401 & 16 \\
\hline 28 & 25 & 0.27 & 0.00 & 0.00 & 0.00 & 0.00 & 0.00 & 0.00 & 997 & 654 & 252 & 0 & 16 \\
\hline 29 & 36 & 0.19 & 0.00 & 0.00 & 0.00 & 0.00 & 0.00 & 0.00 & 1000 & 656 & 2446 & 398 & 16 \\
\hline 30 & 24 & 0.33 & 0.00 & 0.00 & 0.00 & 0.00 & 0.00 & 0.00 & 996 & 1102 & 0 & 0 & 908 \\
\hline 31 & 9 & 0.23 & 0.00 & 0.00 & 0.00 & 0.00 & 0.00 & 0.00 & 999 & 1098 & 0 & 396 & 412 \\
\hline 32 & 30 & 0.00 & 0.02 & 0.01 & 0.01 & 0.01 & 0.03 & 0.08 & 998 & 2666 & 0 & 396 & 890 \\
\hline 33 & 13 & 0.00 & 0.02 & 0.01 & 0.01 & 0.01 & 0.03 & 0.08 & 1007 & 265 & 2468 & 400 & 904 \\
\hline 34 & 4 & 0.00 & 0.02 & 0.01 & 0.01 & 0.01 & 0.03 & 0.09 & 1008 & 2701 & 0 & 0 & 907 \\
\hline 35 & 8 & 0.25 & 0.00 & 0.00 & 0.00 & 0.00 & 0.00 & 0.00 & 996 & 463 & 637 & 401 & 906 \\
\hline 36 & 29 & 0.23 & 0.00 & 0.00 & 0.00 & 0.00 & 0.00 & 0.00 & 995 & 3083 & 0 & 0 & 902 \\
\hline 37 & 34 & 0.18 & 0.00 & 0.00 & 0.00 & 0.00 & 0.00 & 0.00 & 997 & 671 & 2433 & 399 & 900 \\
\hline 38 & 2 & 0.06 & 0.02 & 0.02 & 0.01 & 0.02 & 0.03 & 0.10 & 984 & 2815 & 0 & 395 & 5 \\
\hline 39 & 12 & 0.59 & 0.00 & 0.00 & 0.00 & 0.00 & 0.00 & 0.00 & 999 & 448 & 639 & 0 & 16 \\
\hline 40 & 21 & 0.00 & 0.03 & 0.02 & 0.01 & 0.02 & 0.04 & 0.13 & 996 & 256 & 2456 & 0 & 0 \\
\hline 41 & 10 & 0.00 & 0.02 & 0.01 & 0.01 & 0.01 & 0.03 & 0.09 & 1001 & 255 & 2449 & 409 & 0 \\
\hline 42 & 9 & 0.24 & 0.00 & 0.00 & 0.00 & 0.00 & 0.00 & 0.00 & 999 & 1097 & 0 & 399 & 910 \\
\hline 43 & 22 & 0.00 & 0.05 & 0.03 & 0.02 & 0.03 & 0.07 & 0.21 & 994 & 696 & 0 & 0 & 0 \\
\hline 44 & 6 & 0.37 & 0.00 & 0.00 & 0.00 & 0.00 & 0.00 & 0.00 & 998 & 448 & 636 & 400 & 16 \\
\hline 45 & 15 & 0.27 & 0.00 & 0.00 & 0.00 & 0.00 & 0.00 & 0.00 & 997 & 1401 & 0 & 0 & 16 \\
\hline 46 & 10 & 0.00 & 0.02 & 0.01 & 0.01 & 0.01 & 0.03 & 0.09 & 1003 & 248 & 2440 & 405 & 0 \\
\hline 47 & 23 & 0.00 & 0.03 & 0.02 & 0.01 & 0.02 & 0.04 & 0.13 & 980 & 688 & 0 & 394 & 0 \\
\hline 48 & 17 & 0.00 & 0.03 & 0.02 & 0.01 & 0.02 & 0.03 & 0.10 & 976 & 248 & 2393 & 0 & 0 \\
\hline 49 & 35 & 0.05 & 0.02 & 0.02 & 0.01 & 0.02 & 0.03 & 0.09 & 995 & 391 & 2432 & 405 & 899 \\
\hline 50 & 20 & 0.00 & 0.03 & 0.02 & 0.01 & 0.02 & 0.03 & 0.10 & 1004 & 702 & 0 & 408 & 899 \\
\hline 51 & 5 & 0.06 & 0.03 & 0.02 & 0.01 & 0.02 & 0.04 & 0.11 & 1003 & 388 & 2464 & 0 & 906 \\
\hline
\end{tabular}


Table 7. Performance test results for the initial design

\begin{tabular}{|c|c|c|c|c|c|c|c|c|c|}
\hline \multirow[b]{2}{*}{ Test no. } & \multirow[b]{2}{*}{ Trial no. } & \multirow{2}{*}{$\begin{array}{l}\text { Grout } \\
\text { density } \\
(\mathrm{g} / \mathrm{mL})\end{array}$} & \multirow{2}{*}{$\begin{array}{c}\text { Volume } \\
\text { ratio of } \\
\text { grout to } \\
\text { wet sludge } \\
\end{array}$} & \multirow{2}{*}{$\begin{array}{c}\text { 28-day free } \\
\text { water } \\
\text { (vol \%) }\end{array}$} & \multicolumn{5}{|c|}{ 28- $\mathrm{d}$ unconfined compressive strength (psi) } \\
\hline & & & & & 1 & 2 & 3 & Average & $\begin{array}{l}\text { Standard } \\
\text { deviation }\end{array}$ \\
\hline 1 & Center 1 & 1.63 & 1.34 & 0.00 & 2,378 & 1,918 & 2,428 & 2,241 & 230 \\
\hline 2 & Center 2 & 1.42 & 1.23 & 0.00 & 0 & 0 & 0 & 0 & 0 \\
\hline 3 & Center 1 & 1.63 & 1.34 & 0.00 & 1,798 & 1,940 & 2,120 & 1,953 & 132 \\
\hline 4 & Center 2 & 1.43 & 1.24 & 0.00 & 0 & 0 & 0 & 0 & 0 \\
\hline 5 & 3 & 1.78 & 1.48 & 0.00 & 4,062 & 4,453 & 2,427 & 3,647 & 877 \\
\hline 6 & 8 & 1.49 & 1.26 & 0.00 & 136 & 136 & 136 & 136 & 0 \\
\hline 7 & 18 & 1.52 & 1.24 & 0.00 & 504 & 574 & 581 & 553 & 35 \\
\hline 8 & 5 & 1.66 & 1.41 & 0.00 & 2,393 & 2,388 & 2,520 & 2,433 & 61 \\
\hline 9 & 14 & 1.85 & 1.51 & 0.00 & 4,555 & 4,148 & 6,603 & 5,102 & 1,074 \\
\hline 10 & 31 & 1.86 & 1.41 & 0.00 & 3,183 & 2,903 & 3,213 & 3,099 & 139 \\
\hline 11 & 1 & 1.75 & 1.49 & 0.00 & 2,610 & 2,523 & 2,995 & 2,709 & 205 \\
\hline 12 & 11 & 1.30 & 1.25 & 0.00 & 748 & 561 & 757 & 688 & 91 \\
\hline 13 & 7 & 1.58 & 1.13 & 0.00 & 1,800 & 915 & 1,655 & 1,457 & 388 \\
\hline 14 & 4 & 1.68 & 1.43 & 0.00 & 3,705 & 3,613 & 3,696 & 3,671 & 41 \\
\hline 15 & 2 & 1.66 & 1.14 & 0.00 & 923 & 902 & 711 & 845 & 95 \\
\hline 16 & 28 & 1.60 & 1.45 & 0.00 & 1,968 & 2,040 & 1,770 & 1,926 & 114 \\
\hline 17 & 16 & 1.73 & 1.39 & 0.00 & 3,615 & 3,473 & 3,758 & 3,615 & 116 \\
\hline 18 & 7 & 1.60 & 1.12 & 0.00 & 1,773 & 1,570 & 1,868 & 1,737 & 124 \\
\hline 19 & 19 & 1.70 & 1.46 & 0.00 & 2,530 & 2,563 & 2,535 & 2,543 & 14 \\
\hline 20 & 1 & 1.80 & 1.44 & 0.00 & 3,003 & 3,165 & 3,083 & 3,083 & 66 \\
\hline 21 & 26 & 1.51 & 1.12 & 0.00 & 571 & 930 & 861 & 787 & 156 \\
\hline 22 & 11 & 1.32 & 1.15 & 0.00 & 421 & 588 & 616 & 542 & 86 \\
\hline 23 & 4 & 1.86 & 1.63 & 0.00 & $>6,750$ & $>6,750$ & $>6,750$ & $>6,750$ & \\
\hline 24 & 3 & 1.77 & 1.48 & 0.00 & 4,403 & 4,276 & 4,315 & 4,331 & 53 \\
\hline 25 & 2 & 1.49 & 1.26 & 0.00 & 862 & 787 & 781 & 810 & 37 \\
\hline 26 & 16 & 1.69 & 1.40 & 0.00 & 2,898 & 2,678 & 3,595 & 3,057 & 391 \\
\hline 27 & 6 & 1.29 & 1.32 & 0.00 & 604 & 541 & 604 & 583 & 30 \\
\hline 28 & 25 & 1.80 & 1.50 & 0.00 & 4,745 & 4,465 & 4,883 & 4,698 & 174 \\
\hline 29 & 36 & 1.55 & 1.31 & 0.00 & 1,415 & 1,240 & 1,273 & 1,309 & 76 \\
\hline 30 & 24 & 1.60 & 1.30 & 0.00 & 948 & 955 & 959 & 954 & 4 \\
\hline 31 & 9 & 1.41 & 1.24 & 0.00 & 241 & 242 & 224 & 235 & 8 \\
\hline 32 & 30 & 1.52 & 1.33 & 0.00 & 1,140 & 1,123 & 1,159 & 1,141 & 15 \\
\hline 33 & 13 & 1.51 & 1.35 & 0.00 & 914 & 820 & 929 & 888 & 48 \\
\hline 34 & 4 & 1.61 & 1.34 & 0.00 & 2,416 & 2,790 & 2,200 & 2,469 & 244 \\
\hline 35 & 8 & 1.42 & 1.29 & 0.00 & 255 & 210 & 204 & 223 & 23 \\
\hline 36 & 29 & 1.87 & 1.71 & 0.00 & 5,188 & 5,655 & 6,165 & 5,669 & 399 \\
\hline 37 & 34 & 1.77 & 1.36 & 0.00 & 1,818 & 1,568 & 1,833 & 1,739 & 122 \\
\hline 38 & 2 & 1.45 & 1.26 & 0.00 & 702 & 478 & 755 & 645 & 120 \\
\hline 39 & 12 & 1.70 & 1.20 & 0.00 & 772 & 875 & 790 & 812 & 45 \\
\hline 40 & 21 & 1.81 & 1.51 & 0.00 & No Value & 3,646 & 2,613 & 2,086 & 1,534 \\
\hline 41 & 10 & 1.46 & 1.26 & 0.00 & 703 & 756 & 695 & 718 & 27 \\
\hline 42 & 9 & 1.45 & 1.26 & 0.00 & 303 & 296 & 270 & 289 & 14 \\
\hline
\end{tabular}


Table 7. Performance test results for the initial design (continued)

\begin{tabular}{|c|c|c|c|c|c|c|c|c|c|}
\hline \multirow[b]{2}{*}{ Test no. } & \multirow[b]{2}{*}{ Trial no. } & \multirow{2}{*}{$\begin{array}{l}\text { Grout } \\
\text { density } \\
\text { (g/mL) }\end{array}$} & \multirow{2}{*}{$\begin{array}{l}\text { Volume } \\
\text { ratio of } \\
\text { grout to } \\
\text { wet sludge }\end{array}$} & \multirow{2}{*}{$\begin{array}{c}\text { 28-day free } \\
\text { water } \\
\text { (vol \%) }\end{array}$} & \multicolumn{5}{|c|}{ 28-d unconfined compressive strength (psi) } \\
\hline & & & & & 1 & 2 & 3 & Average & $\begin{array}{l}\text { Standard } \\
\text { deviation }\end{array}$ \\
\hline & 22 & 1.49 & 1.11 & 0.00 & 195 & 190 & 176 & 187 & 8 \\
\hline \multicolumn{10}{|l|}{43} \\
\hline 44 & 6 & 1.43 & 1.18 & 0.00 & 455 & 571 & 582 & 536 & 57 \\
\hline 45 & 15 & 1.92 & 1.44 & 0.00 & 3,118 & 4,543 & 4,930 & 4,197 & 779 \\
\hline 46 & 10 & 1.47 & 1.25 & 0.00 & 1,012 & 972 & 1,026 & 1,003 & 23 \\
\hline 47 & 23 & 1.27 & 1.16 & 0.00 & 0 & 0 & 0 & 0 & 0 \\
\hline 48 & 17 & 1.56 & 1.28 & 0.00 & 1,227 & 1,153 & 1,187 & 1,189 & 31 \\
\hline 49 & 35 & 1.52 & 1.36 & 0.00 & 1,763 & 1,870 & 1,610 & 1,748 & 107 \\
\hline 50 & 20 & 1.33 & 1.21 & 0.00 & 0 & 0 & 0 & 0 & 0 \\
\hline 51 & 5 & 1.62 & 1.41 & 0.00 & 2,188 & 2,026 & 2,353 & 2,189 & 133 \\
\hline
\end{tabular}


Table 8. TCLP performance of the initial-design grouts

\begin{tabular}{|c|c|c|c|c|c|c|c|c|c|c|c|}
\hline \multirow[b]{2}{*}{ Test } & \multirow[b]{2}{*}{ Trial } & \multicolumn{5}{|c|}{ TCLP extract concentration $(\mathrm{mg} / \mathrm{L})$} & \multicolumn{5}{|c|}{ RCRA metal extracted in TCLP test (mass fraction) } \\
\hline & & $\mathrm{Cd}$ & $\mathrm{Cr}$ & $\mathrm{Ni}$ & $\mathrm{Pb}$ & $\mathrm{Hg}$ & $\mathrm{Cd}$ & $\mathrm{Cr}$ & $\mathrm{Ni}$ & $\mathrm{Pb}$ & $\mathrm{Hg}$ \\
\hline 1 & Center 1 & $<0.0011$ & 0.008 & $<0.006$ & 0.03500 & 0.00076 & 0.0000 & 0.0023 & 0.0000 & 0.0039 & 0.000063 \\
\hline 2 & Center 2 & $<0.001$ & 0.005 & 0.008 & 0.00900 & $<0.00005$ & 0.0000 & 0.0086 & 0.0030 & 0.0012 & 0.000000 \\
\hline 3 & Center 1 & $<0.001$ & $<0.003$ & $<0.006$ & $<0.008$ & 0.30300 & 0.0000 & 0.0000 & 0.0000 & 0.0000 & 0.024914 \\
\hline 4 & Center 2 & $<0.001$ & $<0.003$ & $<0.006$ & $<0.008$ & $<0.00005$ & 0.0000 & 0.0000 & 0.0000 & 0.0000 & 0.000000 \\
\hline 5 & 3 & $<0.001$ & 1.43 & $<0.006$ & $<0.008$ & $<0.00005$ & & 0.1379 & 0.0000 & 0.0000 & \\
\hline 6 & 8 & 0.007 & $<0.003$ & 0.033 & 0.01800 & 0.00021 & 0.0022 & 0.0000 & 0.0051 & 0.0022 & 0.000048 \\
\hline 7 & 18 & $<0.001$ & 1.93 & $<0.006$ & $<0.008$ & $<0.00005$ & & 0.4288 & 0.0000 & 0.0000 & \\
\hline 8 & 5 & $<0.001$ & $<0.003$ & $<0.006$ & $<0.008$ & $<0.00005$ & & 0.0000 & 0.0000 & 0.0000 & 0.000000 \\
\hline 9 & 14 & $<0.001$ & 1.726 & $<0.006$ & $<0.008$ & $<0.00005$ & & 0.1391 & 0.0000 & 0.0000 & \\
\hline 10 & 31 & $<0.001$ & 1.32 & $<0.006$ & $<0.008$ & $<0.00005$ & & 0.0876 & 0.0000 & 0.0000 & \\
\hline 11 & 1 & $<0.001$ & 0.83 & $<0.006$ & $<0.008$ & & 0.0000 & 0.0617 & 0.0000 & 0.0000 & \\
\hline 12 & 11 & 0.004 & $<0.003$ & $<0.006$ & 0.01300 & 0.00016 & 0.0010 & 0.0000 & & 0.0012 & 0.000023 \\
\hline 13 & 7 & $<0.001$ & 0.005 & 0.011 & $<0.008$ & 0.03699 & & 0.0013 & 0.0545 & 0.0000 & 0.003770 \\
\hline 14 & 4 & $<0.011$ & 1.28 & $<0.056$ & $<0.078$ & $<0.00005$ & & 0.1327 & 0.0000 & 0.0000 & \\
\hline 15 & 2 & $<0.001$ & 0.3 & $<0.006$ & $<0.008$ & $<0.00005$ & 0.0000 & 0.0323 & 0.0000 & 0.0000 & \\
\hline 16 & 28 & $<0.001$ & $<0.003$ & $<0.006$ & $<0.008$ & 0.00028 & 0.0000 & 0.0000 & 0.0000 & 0.0000 & 0.000020 \\
\hline 17 & 16 & $<0.001$ & 1.97 & $<0.006$ & $<0.008$ & & 0.0000 & 0.1561 & 0.0000 & 0.0000 & \\
\hline 18 & 7 & $<0.001$ & 0.057 & 0.006 & $<0.008$ & 0.00346 & & 0.0149 & 0.0298 & 0.0000 & 0.000356 \\
\hline 19 & 19 & $<0.001$ & $<0.003$ & 0.008 & 0.01000 & 0.00043 & & 0.0000 & 0.0016 & 0.0015 & 0.000027 \\
\hline 20 & 1 & $<0.001$ & 0.92 & $<0.006$ & $<0.008$ & & 0.0000 & 0.0687 & 0.0000 & 0.0000 & \\
\hline 21 & 26 & $<0.001$ & $<0.003$ & $<0.006$ & $<0.008$ & $<0.00005$ & & 0.0000 & 0.0000 & 0.0000 & 0.000000 \\
\hline 22 & 11 & $<0.002$ & $<0.003$ & $<0.006$ & 0.00900 & $<0.00005$ & 0.0000 & 0.0000 & & 0.0010 & 0.000000 \\
\hline 23 & 4 & $<0.002$ & 2.14 & $<0.006$ & $<0.008$ & $<0.00005$ & & 0.1917 & 0.0000 & 0.0000 & \\
\hline 24 & 3 & $<0.001$ & 1.58 & $<0.006$ & $<0.008$ & $<0.00005$ & & 0.1519 & 0.0000 & 0.0000 & \\
\hline 25 & 2 & $<0.011$ & 0.275 & $<0.06$ & $<0.08$ & $<0.00005$ & 0.0000 & 0.0297 & 0.0000 & 0.0000 & \\
\hline 26 & 16 & $<0.001$ & 2.33 & $<0.006$ & $<0.008$ & 0.00006 & 0.0000 & 0.1865 & 0.0000 & 0.0000 & \\
\hline 27 & 6 & $<0.001$ & $<0.003$ & 0.011 & 0.00900 & $<0.00005$ & 0.0000 & 0.0000 & 0.0750 & 0.0008 & 0.000000 \\
\hline 28 & 25 & $<0.001$ & $<0.003$ & $<0.006$ & $<0.008$ & 0.00202 & & 0.0000 & 0.0000 & 0.0000 & 0.000910 \\
\hline 29 & 36 & $<0.001$ & 0.004 & $<0.006$ & $<0.008$ & 0.00099 & 0.0000 & 0.0017 & 0.0000 & 0.0000 & 0.000064 \\
\hline 30 & 24 & $<0.001$ & 2.46 & $<0.006$ & $<0.008$ & & & 0.3627 & 0.0000 & 0.0000 & \\
\hline
\end{tabular}


Table 8. TCLP performance of the initial-design grouts (continued)

\begin{tabular}{|c|c|c|c|c|c|c|c|c|c|c|c|}
\hline \multirow[b]{2}{*}{ Test } & \multirow[b]{2}{*}{ Trial } & \multicolumn{5}{|c|}{ TCLP extract concentration (mg/L) } & \multicolumn{5}{|c|}{ RCRA metal extracted in TCLP test (mass fraction) } \\
\hline & & $\mathrm{Cd}$ & $\mathrm{Cr}$ & $\mathrm{Ni}$ & $\mathrm{Pb}$ & $\mathrm{Hg}$ & $\mathrm{Cd}$ & $\mathrm{Cr}$ & $\mathrm{Ni}$ & $\mathrm{Pb}$ & $\mathrm{Hg}$ \\
\hline 31 & 9 & 0.002 & 2.25 & $<0.006$ & $<0.008$ & & 0.0007 & 0.4792 & 0.0000 & 0.000000 & \\
\hline 32 & 30 & $<0.011$ & 1.6 & $<0.056$ & $<0.08$ & $<0.00005$ & 0.0000 & 0.2087 & 0.0000 & 0.000000 & \\
\hline 33 & 13 & $<0.002$ & $<0.003$ & $<0.006$ & $<0.008$ & $<0.00005$ & 0.0000 & 0.0000 & 0.0000 & 0.000000 & 0.000000 \\
\hline 34 & 4 & $<0.001$ & 0.701 & $<0.006$ & $<0.008$ & $<0.00005$ & & 0.0785 & 0.0000 & 0.000000 & \\
\hline 35 & 8 & 0.015 & 0.016 & 0.023 & 0.03800 & 0.01529 & 0.0049 & 0.0076 & 0.0037 & 0.004713 & 0.002975 \\
\hline 36 & 29 & $<0.001$ & 2.13 & $<0.006$ & $<0.008$ & $<0.00005$ & & 0.1615 & 0.0000 & 0.000000 & \\
\hline 37 & 34 & $<0.001$ & $<0.003$ & $<0.006$ & $<0.008$ & 0.00067 & 0.0000 & 0.0000 & 0.0000 & 0.000000 & 0.000046 \\
\hline 38 & 2 & $<0.001$ & 0.308 & $<0.006$ & $<0.008$ & $<0.00005$ & 0.0000 & 0.0346 & 0.0000 & 0.000000 & \\
\hline 39 & 12 & $<0.001$ & 0.005 & $<0.006$ & $<0.008$ & 0.00069 & & 0.0011 & 0.0000 & 0.000000 & 0.000060 \\
\hline 40 & 21 & $<0.002$ & $<0.003$ & $<0.006$ & $<0.008$ & $<0.00005$ & & 0.0000 & & 0.000000 & 0.000000 \\
\hline 41 & 10 & $<0.001$ & $<0.003$ & $<0.006$ & $<0.008$ & $<0.00005$ & 0.0000 & 0.0000 & & 0.000000 & 0.000000 \\
\hline 42 & 9 & 0.002 & 2.59 & $<0.006$ & $<0.008$ & & 0.0007 & 0.5260 & 0.0000 & 0.000000 & \\
\hline 43 & 22 & $<0.001$ & 4.42 & $<0.006$ & $<0.008$ & $<0.00005$ & & 0.8084 & & 0.000000 & \\
\hline 44 & 6 & 0.003 & $<0.003$ & 0.011 & $<0.008$ & $<0.00005$ & 0.0007 & 0.0000 & 0.0750 & 0.000000 & 0.000000 \\
\hline 45 & 15 & $<0.001$ & 2.72 & $<0.006$ & $<0.008$ & $<0.00005$ & & 0.3849 & 0.0000 & 0.000000 & \\
\hline 46 & 10 & $<0.002$ & $<0.003$ & $<0.006$ & $<0.008$ & $<0.00005$ & 0.0000 & 0.0000 & & 0.000000 & 0.000000 \\
\hline 47 & 23 & $<0.001$ & 3.031 & $<0.006$ & $<0.008$ & $<0.00005$ & 0.0000 & 0.8958 & & 0.000000 & \\
\hline 48 & 17 & $<0.001$ & $<0.003$ & $<0.006$ & $<0.008$ & $<0.00005$ & & 0.0000 & & 0.000000 & 0.000000 \\
\hline 49 & 35 & $<0.001$ & $<0.003$ & $<0.006$ & $<0.008$ & 0.00023 & 0.0000 & 0.0000 & 0.0000 & 0.000000 & 0.000018 \\
\hline 50 & 20 & 0.029 & 2.26 & $<0.006$ & $<0.008$ & 0.00005 & 0.0111 & 0.8462 & 0.0000 & 0.000000 & \\
\hline 51 & 5 & $<0.001$ & $<0.003$ & $<0.006$ & $<0.008$ & $<0.00005$ & & 0.0000 & 0.0000 & 0.000000 & 0.000000 \\
\hline
\end{tabular}


Table 9. Components of the sequential statistical design

\begin{tabular}{|c|c|c|c|c|c|c|c|c|c|c|c|}
\hline \multirow{3}{*}{ Trial } & \multirow{2}{*}{\multicolumn{3}{|c|}{$\begin{array}{l}\text { Ratio of dry blend/ } \\
\text { waste solids }\end{array}$}} & \multirow{2}{*}{\multicolumn{3}{|c|}{$\begin{array}{l}\text { Statistical designation of waste } \\
\text { solids composition }\end{array}$}} & \multicolumn{5}{|c|}{ Corresponding experimental application } \\
\hline & & & & & & & \multirow[b]{2}{*}{$\begin{array}{l}\text { Sludge } \\
\text { source }\end{array}$} & \multicolumn{4}{|c|}{$\begin{array}{c}\text { Salt mass fraction in unit } \\
\text { waste solids }\end{array}$} \\
\hline & Cement & Slag & Total & $\begin{array}{l}\text { Sludge } \\
\text { source }\end{array}$ & $\mathrm{CaSO}_{4}$ & $\mathrm{NaCl}$ & & $\mathrm{CaSO}_{4}$ & $\mathrm{NaCl}$ & $\mathrm{NaNO}_{3}$ & Total \\
\hline 1 & 0.04 & 0.21 & 0.25 & 1 & 1 & -1 & ECM & 0.1 & 0 & 0.6 & 0.7 \\
\hline 1 & 0.04 & 0.21 & 0.25 & 1 & -1 & 1 & $\mathrm{ECM}$ & 0 & 0.2 & 0.5 & 0.7 \\
\hline 1 & 0.04 & 0.21 & 0.25 & 0 & 1 & 1 & MWFA & 0.1 & 0.2 & 0.4 & 0.7 \\
\hline 1 & 0.04 & 0.21 & 0.25 & 0 & -1 & -1 & MWFA & 0 & 0 & 0.7 & 0.7 \\
\hline 2 & 0.24 & 0.26 & 0.5 & 1 & 1 & 1 & $\mathrm{ECM}$ & 0.1 & 0.2 & 0.4 & 0.7 \\
\hline 2 & 0.24 & 0.26 & 0.5 & 1 & -1 & -1 & ECM & 0 & 0 & 0.7 & 0.7 \\
\hline 2 & 0.24 & 0.26 & 0.5 & 0 & 1 & -1 & MWFA & 0.1 & 0 & 0.6 & 0.7 \\
\hline 2 & 0.24 & 0.26 & 0.5 & 0 & -1 & 1 & MWFA & 0 & 0.2 & 0.5 & 0.7 \\
\hline 3 & 0.14 & 0.11 & 0.25 & 1 & 1 & -1 & ECM & 0.1 & 0 & 0.6 & 0.7 \\
\hline 3 & 0.14 & 0.11 & 0.25 & 1 & -1 & 1 & ECM & 0 & 0.2 & 0.5 & 0.7 \\
\hline 3 & 0.14 & 0.11 & 0.25 & 0 & 1 & 1 & MWFA & 0.1 & 0.2 & 0.4 & 0.7 \\
\hline 3 & 0.14 & 0.11 & 0.25 & 0 & -1 & -1 & MWFA & 0 & 0 & 0.7 & 0.7 \\
\hline 4 & 0.06 & 0.31 & 0.37 & 1 & 1 & 1 & $\mathrm{ECM}$ & 0.1 & 0.2 & 0.4 & 0.7 \\
\hline 4 & 0.06 & 0.31 & 0.37 & 1 & -1 & -1 & ECM & 0 & 0 & 0.7 & 0.7 \\
\hline 4 & 0.06 & 0.31 & 0.37 & 0 & 1 & -1 & MWFA & 0.1 & 0 & 0.6 & 0.7 \\
\hline 4 & 0.06 & 0.31 & 0.37 & 0 & -1 & 1 & MWFA & 0 & 0.2 & 0.5 & 0.7 \\
\hline 5 & 0.08 & 0.42 & 0.5 & 1 & 1 & 1 & $\mathrm{ECM}$ & 0.1 & 0.2 & 0.4 & 0.7 \\
\hline 5 & 0.08 & 0.42 & 0.5 & 1 & -1 & -1 & ECM & 0 & 0 & 0.7 & 0.7 \\
\hline 5 & 0.08 & 0.42 & 0.5 & 0 & -1 & 1 & MWFA & 0 & 0.2 & 0.5 & 0.7 \\
\hline 5 & 0.08 & 0.42 & 0.5 & 0 & 1 & -1 & MWFA & 0.1 & 0 & 0.6 & 0.7 \\
\hline 11 & 0.39 & 0.11 & 0.5 & 1 & 1 & -1 & ECM & 0.1 & 0 & 0.6 & 0.7 \\
\hline 11 & 0.39 & 0.11 & 0.5 & 1 & -1 & 1 & ECM & 0 & 0.2 & 0.5 & 0.7 \\
\hline 11 & 0.39 & 0.11 & 0.5 & 0 & 1 & 1 & MWFA & 0.1 & 0.2 & 0.4 & 0.7 \\
\hline 11 & 0.39 & 0.11 & 0.5 & 0 & -1 & -1 & MWFA & 0 & 0 & 0.7 & 0.7 \\
\hline 19 & 0.27 & 0.11 & 0.38 & 1 & -1 & 1 & ECM & 0 & 0.2 & 0.5 & 0.7 \\
\hline 19 & 0.27 & 0.11 & 0.38 & 1 & 1 & -1 & ECM & 0.1 & 0 & 0.6 & 0.7 \\
\hline 19 & 0.27 & 0.11 & 0.38 & 0 & 1 & 1 & MWFA & 0.1 & 0.2 & 0.4 & 0.7 \\
\hline 19 & 0.27 & 0.11 & 0.38 & 0 & -1 & -1 & MWFA & 0 & 0 & 0.7 & 0.7 \\
\hline 32 & 0.16 & 0.21 & 0.37 & 1 & 1 & 1 & ECM & 0.1 & 0.2 & 0.4 & 0.7 \\
\hline 32 & 0.16 & 0.21 & 0.37 & 1 & -1 & -1 & ECM & 0 & 0 & 0.7 & 0.7 \\
\hline 32 & 0.16 & 0.21 & 0.37 & 0 & 1 & -1 & MWFA & 0.1 & 0 & 0.6 & 0.7 \\
\hline 32 & 0.16 & 0.21 & 0.37 & 0 & -1 & 1 & MWFA & 0 & 0.2 & 0.5 & 0.7 \\
\hline
\end{tabular}


Table 10. Composition of grouts for the sequential design

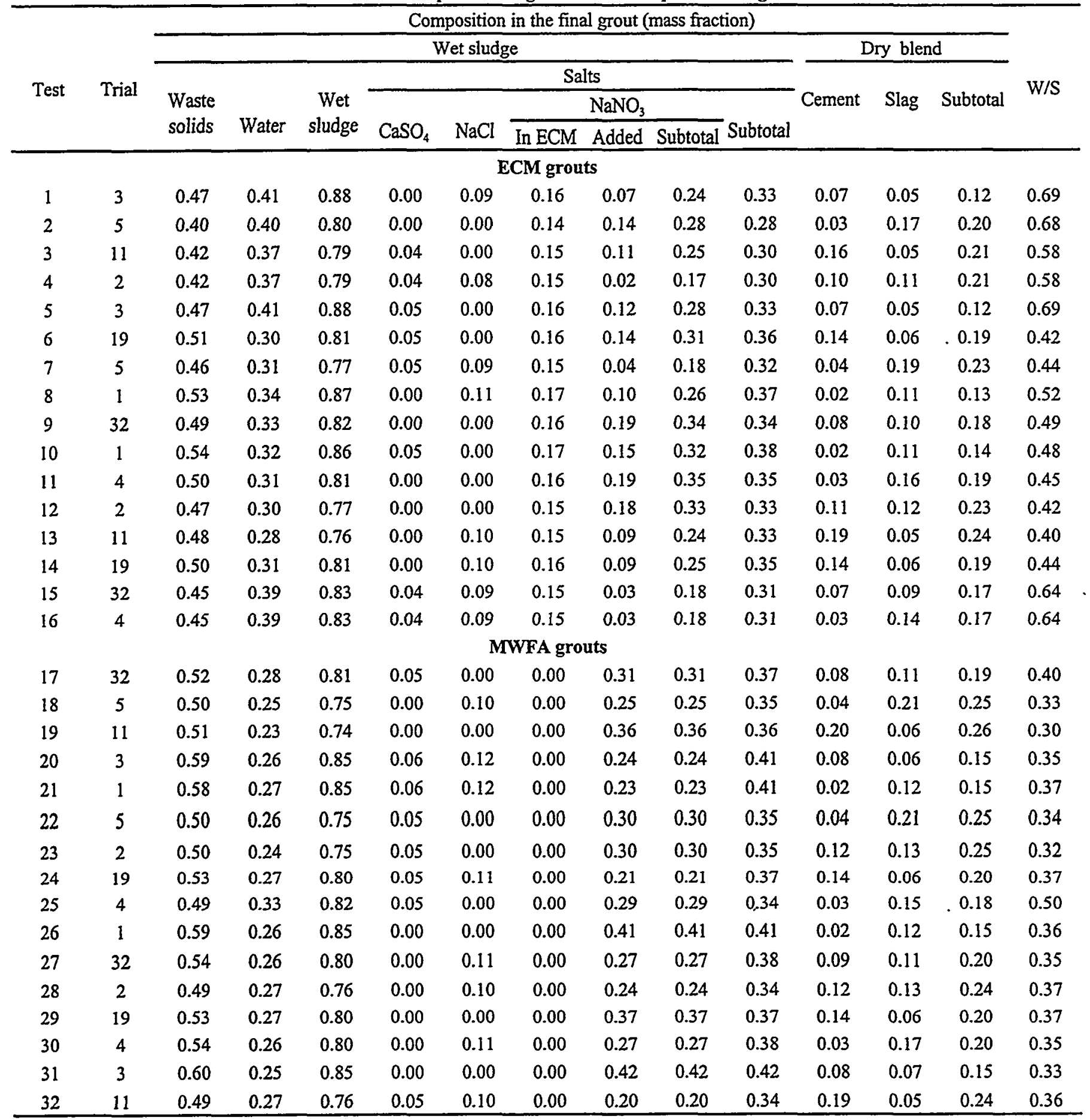


Table 11. Additional data for the wet-sludge makeup for the sequential-design grouts

\begin{tabular}{|c|c|c|c|c|c|c|c|c|c|c|c|c|c|}
\hline \multirow{3}{*}{ Test } & \multirow{3}{*}{ Trial } & \multicolumn{7}{|c|}{ Composition in the final grout (mass fraction) } & \multicolumn{5}{|c|}{$\begin{array}{l}\text { RCRA compound concentration in waste } \\
\text { solids (mg } / \mathrm{kg} \text { ) }\end{array}$} \\
\hline & & \multirow{2}{*}{$\begin{array}{l}\text { Wet ECM } \\
\text { Sludge }\end{array}$} & \multicolumn{6}{|c|}{ MWFA Other Solids } & \multirow[b]{2}{*}{$\mathrm{PbO}$} & \multirow[b]{2}{*}{$\mathrm{CrO}_{3}$} & \multirow[b]{2}{*}{$\mathrm{HgO}$} & \multirow[b]{2}{*}{$\mathrm{CdO}$} & \multirow[b]{2}{*}{$\mathrm{NiO}$} \\
\hline & & & $\mathrm{Fe}_{2} \mathrm{O}_{3}$ & $\mathrm{Al}(\mathrm{OH})_{3}$ & $\mathrm{Na}_{3} \mathrm{PO}_{4} \cdot 12 \mathrm{H}_{2}$ & $\mathrm{Kg}(\mathrm{OH})_{2}$ & $\mathrm{CaSiO}_{3}$ & Subtotal & & & & & \\
\hline \multicolumn{14}{|c|}{ ECM Grouts } \\
\hline 1 & 3 & 0.71 & 0.00 & 0.00 & 0.00 & 0.00 & 0.00 & 0.00 & 988 & 1382 & 1002 & 1002 & 1017 \\
\hline 2 & 5 & 0.60 & 0.00 & 0.00 & 0.00 & 0.00 & 0.00 & 0.00 & 1001 & 1388 & 1002 & 1001 & 1013 \\
\hline 3 & 11 & 0.64 & 0.00 & 0.00 & 0.00 & 0.00 & 0.00 & 0.00 & 1002 & 1384 & 1002 & 1000 & 1015 \\
\hline 4 & 2 & 0.64 & 0.00 & 0.00 & 0.00 & 0.00 & 0.00 & 0.00 & 1000 & 1385 & 1001 & 1001 & 1015 \\
\hline 5 & 3 & 0.71 & 0.00 & 0.00 & 0.00 & 0.00 & 0.00 & 0.00 & 1001 & 1383 & 1001 & 1000 & 1016 \\
\hline 6 & 19 & 0.55 & 0.00 & 0.00 & 0.00 & 0.00 & 0.00 & 0.00 & 1000 & 1303 & 1001 & 1000 & 1015 \\
\hline 7 & 5 & 0.50 & 0.00 & 0.00 & 0.00 & 0.00 & 0.00 & 0.00 & 999 & 1304 & 1000 & 999 & 1013 \\
\hline 8 & 1 & 0.57 & 0.00 & 0.00 & 0.00 & 0.00 & 0.00 & 0.00 & 999 & 1303 & 1000 & 999 & 1013 \\
\hline 9 & 32 & 0.53 & 0.00 & 0.00 & 0.00 & 0.00 & 0.00 & 0.00 & 1000 & 1305 & 1000 & 1000 & 1014 \\
\hline 10 & 1 & 0.59 & 0.00 & 0.00 & 0.00 & 0.00 & 0.00 & 0.00 & 999 & 1305 & 1000 & 1000 & 1015 \\
\hline 11 & 4 & 0.55 & 0.00 & 0.00 & 0.00 & 0.00 & 0.00 & 0.00 & 1000 & 1304 & 1001 & 1001 & 1013 \\
\hline 12 & 2 & 0.51 & 0.00 & 0.00 & 0.00 & 0.00 & 0.00 & 0.00 & 1000 & 1310 & 1000 & 1000 & 1014 \\
\hline 13 & 11 & 0.52 & 0.00 & 0.00 & 0.00 & 0.00 & 0.00 & 0.00 & 998 & 1300 & 1001 & 999 & 1016 \\
\hline 14 & 19 & 0.55 & 0.00 & 0.00 & 0.00 & 0.00 & 0.00 & 0.00 & 1000 & 1303 & 1000 & 999 & 1014 \\
\hline 15 & 32 & 0.67 & 0.00 & 0.00 & 0.00 & 0.00 & 0.00 & 0.00 & 1001 & 1332 & 999 & 1000 & 1018 \\
\hline 16 & 4 & 0.67 & 0.00 & 0.00 & 0.00 & 0.00 & 0.00 & 0.00 & 998 & 1332 & 999 & 1000 & 1018 \\
\hline \multicolumn{14}{|c|}{ MWFA Grouts } \\
\hline 17 & 32 & 0.00 & 0.04 & 0.03 & 0.01 & 0.03 & 0.05 & 0.15 & 1001 & 1008 & 1000 & 999 & 999 \\
\hline 18 & 5 & 0.00 & 0.04 & 0.03 & 0.01 & 0.03 & 0.05 & 0.15 & 1003 & 1003 & 999 & 1001 & 999 \\
\hline 19 & 11 & 0.00 & 0.04 & 0.03 & 0.01 & 0.03 & 0.05 & 0.15 & 1000 & 1002 & 1001 & 1001 & 1001 \\
\hline 20 & 3 & 0.00 & 0.04 & 0.03 & 0.02 & 0.03 & 0.06 & 0.18 & 1002 & 1002 & 1347 & 1000 & 1004 \\
\hline 21 & 1 & 0.00 & 0.04 & 0.03 & 0.01 & 0.03 & 0.06 & 0.17 & 1002 & 1003 & 1006 & 1005 & 1003 \\
\hline 22 & 5 & 0.00 & 0.04 & 0.02 & 0.01 & 0.02 & 0.05 & 0.15 & 1001 & 997 & 1003 & 999 & 998 \\
\hline 23 & 2 & 0.00 & 0.04 & 0.03 & 0.01 & 0.03 & 0.05 & 0.15 & 1004 & 1000 & 998 & 1002 & 1000 \\
\hline 24 & 19 & 0.00 & 0.04 & 0.03 & 0.01 & 0.03 & 0.05 & 0.16 & 1002 & 1003 & 1001 & 1001 & 1001 \\
\hline 25 & 4 & 0.00 & 0.04 & 0.02 & 0.01 & 0.02 & 0.05 & 0.14 & 1001 & 1000 & 1000 & 999 & 1001 \\
\hline 26 & 1 & 0.00 & 0.04 & 0.03 & 0.01 & 0.03 & 0.06 & 0.17 & 1001 & 1001 & 1002 & 999 & 999 \\
\hline 27 & 32 & 0.00 & 0.04 & 0.03 & 0.01 & 0.03 & 0.05 & 0.16 & 1000 & 1007 & 1001 & 1000 & 999 \\
\hline 28 & 2 & 0.00 & 0.04 & 0.02 & 0.01 & 0.02 & 0.05 & 0.14 & 998 & 1001 & 1000 & 1001 & 1001 \\
\hline 29 & 19 & 0.00 & 0.04 & 0.03 & 0.01 & 0.03 & 0.05 & 0.16 & 1002 & 999 & 1001 & 999 & 1001 \\
\hline 30 & 4 & 0.00 & 0.04 & 0.03 & 0.01 & 0.03 & 0.05 & 0.16 & 999 & 997 & 999 & 1000 & 1000 \\
\hline 31 & 3 & 0.00 & 0.04 & 0.03 & 0.02 & 0.03 & 0.06 & 0.18 & 1001 & 1001 & 1001 & 999 & 1000 \\
\hline 32 & 11 & 0.00 & 0.04 & 0.02 & 0.01 & 0.02 & 0.05 & 0.14 & 1002 & 1000 & 1002 & 1001 & 1003 \\
\hline
\end{tabular}


Table 12. Performance test results for the sequential-design grouts

\begin{tabular}{|c|c|c|c|c|c|c|c|c|c|}
\hline \multirow[b]{2}{*}{ Test No. } & \multirow[b]{2}{*}{ Trial No. } & \multirow{2}{*}{$\begin{array}{l}\text { Grout } \\
\text { density } \\
(\mathrm{g} / \mathrm{mL})\end{array}$} & \multirow{2}{*}{$\begin{array}{c}\text { Volume } \\
\text { ratio of } \\
\text { grout to } \\
\text { wet sludge }\end{array}$} & \multirow[b]{2}{*}{$\begin{array}{c}28-\mathrm{d} \text { free water } \\
\text { (vol. \%) }\end{array}$} & \multicolumn{5}{|c|}{ 28-d unconfined compressive strength (psi) } \\
\hline & & & & & 1 & 2 & 3 & Average & $\begin{array}{r}\text { Standard } \\
\text { deviation }\end{array}$ \\
\hline \multicolumn{10}{|c|}{ ECM grouts } \\
\hline 10 & 1 & 1.82 & 0.95 & 0.00 & 0 & 0 & 0 & 0 & 0 \\
\hline 8 & 1 & 1.73 & 0.97 & 0.00 & 0 & 0 & 0 & 0 & 0 \\
\hline 12 & 2 & 1.82 & 1.06 & 0.00 & 497 & 457 & 465 & 473 & 18 \\
\hline 4 & 2 & 1.69 & 1.12 & 0.00 & 277 & 292 & 301 & 290 & 10 \\
\hline 1 & 3 & 1.67 & 1.01 & 0.00 & 0 & 0 & 0 & 0 & 0 \\
\hline 5 & 3 & 1.87 & 0.91 & 0.00 & 0 & 0 & 0 & 0 & 0 \\
\hline 11 & 4 & 1.88 & 0.96 & 0.00 & 0 & 0 & 0 & 0 & 0 \\
\hline 16 & 4 & 1.69 & 1.06 & 0.00 & 0 & 0 & 0 & 0 & 0 \\
\hline 2 & 5 & 1.68 & 1.07 & 0.00 & 550 & 604 & 525 & 560 & 33 \\
\hline 7 & 5 & & & 0.00 & 123 & 151 & 137 & 137 & 12 \\
\hline 3 & 11 & 1.74 & 1.10 & 0.00 & 276 & 351 & 291 & 306 & 32 \\
\hline 13 & 11 & 1.83 & 1.06 & 0.00 & 558 & 513 & 515 & 528 & 21 \\
\hline 14 & 19 & 1.92 & 0.95 & 0.00 & 319 & 331 & 303 & 318 & 11 \\
\hline 6 & 19 & & & 0.00 & 359 & 402 & 350 & 370 & 23 \\
\hline 9 & 32 & 1.79 & 0.99 & 0.00 & 0 & 0 & 0 & 0 & 0 \\
\hline 15 & 32 & 1.71 & 1.05 & 0.00 & 0 & 0 & 0 & 0 & 0 \\
\hline \multicolumn{10}{|c|}{ MWFA grouts } \\
\hline 21 & 1 & 1.77 & 1.10 & 0.00 & 438 & 470 & 459 & 456 & 13 \\
\hline 26 & 1 & 1.78 & 1.10 & 0.00 & 0 & 0 & 0 & 0 & 0 \\
\hline 28 & 2 & 1.83 & 1.15 & 0.00 & 0 & 0 & 0 & 0 & 0 \\
\hline 23 & 2 & 1.88 & 1.17 & 0.00 & 874 & 964 & 991 & 943 & 50 \\
\hline 31 & 3 & 1.84 & 1.09 & 0.00 & 707 & 752 & 756 & 738 & 22 \\
\hline 20 & 3 & 1.81 & 1.09 & 0.00 & 204 & 210 & 202 & 205 & 4 \\
\hline 25 & 4 & 1.82 & 1.03 & 0.00 & 0 & 0 & 0 & 0 & 0 \\
\hline 30 & 4 & 1.79 & 1.14 & 0.00 & 0 & 0 & 0 & 0 & 0 \\
\hline 18 & 5 & 1.84 & 1.18 & 0.00 & 1,244 & 1,308 & 1,188 & 1,246 & 49 \\
\hline 22 & 5 & 1.86 & 1.17 & 0.00 & 1,200 & 1,227 & 1,246 & 1,225 & 19 \\
\hline 32 & 11 & 1.81 & 1.17 & 0.00 & 0 & 0 & 0 & 0 & 0 \\
\hline 19 & 11 & 1.86 & 1.20 & 0.00 & 1,276 & 1,202 & 1,292 & 1,257 & 40 \\
\hline 24 & 19 & 1.78 & 1.14 & 0.00 & 0 & 0 & 0 & 0 & 0 \\
\hline 29 & 19 & 1.79 & 1.13 & 0.00 & 0 & 0 & 0 & 0 & 0 \\
\hline 27 & 32 & 1.82 & 1.13 & 0.00 & 0 & 0 & 0 & 0 & 0 \\
\hline 17 & 32 & 1.78 & 1.12 & 0.00 & 221 & 237 & 258 & 239 & 15 \\
\hline
\end{tabular}


Table 13. TCLP performance of the sequential-design grouts

\begin{tabular}{|c|c|c|c|c|c|c|c|c|c|c|c|}
\hline \multirow[b]{2}{*}{ Test. } & \multirow[b]{2}{*}{ Trial } & \multicolumn{5}{|c|}{ TCLP extract concentration $(\mathrm{mg} / \mathrm{L})$} & \multicolumn{5}{|c|}{ RCRA metal extracted in TCLP test (mass fraction) } \\
\hline & & $\mathrm{Cd}$ & $\mathrm{Cr}_{\mathrm{r}}$ & $\mathrm{Ni}$ & $\mathrm{Pb}$ & $\mathrm{Hg}$ & $\mathrm{Cd}$ & $\mathrm{Cr}$ & $\mathrm{Ni}$ & $\mathrm{Pb}$ & $\mathrm{Hg}$ \\
\hline \multicolumn{12}{|c|}{ ECM grouts } \\
\hline 10 & 1 & 0.004 & 0.321 & 0.098 & 0.016 & 0.00127 & 0.0002 & 0.0175 & 0.0045 & 0.0006 & 0.000051 \\
\hline 8 & 1 & 0.130 & 0.110 & 0.134 & 0.032 & 0.04000 & 0.0057 & 0.0062 & 0.0064 & 0.0013 & 0.000016 \\
\hline 12 & 2 & $<0.003$ & 0.219 & $<0.010$ & $<0.014$ & 0.00006 & 0.0000 & 0.0137 & 0.0000 & 0.0000 & 0.000003 \\
\hline 4 & 2 & $<0.003$ & 0.100 & $<0.010$ & $<0.014$ & 0.00020 & 0.0000 & 0.0066 & 0.0000 & 0.0000 & 0.000010 \\
\hline 1 & 3 & 0.024 & 0.837 & 0.085 & 0.016 & 0.00024 & 0.0012 & 0.0493 & 0.0045 & 0.0007 & 0.000011 \\
\hline 5 & 3 & 2.630 & 3.020 & 0.111 & $<0.014$ & 0.00079 & 0.1271 & 0.1777 & 0.0059 & 0.0000 & 0.000036 \\
\hline 11 & 4 & $<0.003$ & 0.037 & 0.024 & $<0.014$ & 0.00037 & 0.0000 & 0.0022 & 0.0012 & 0.0000 & 0.000016 \\
\hline 16 & 4 & $<0.003$ & 0.155 & 0.062 & $<0.014$ & 0.00098 & 0.0000 & 0.0100 & 0.0035 & 0.0000 & 0.000048 \\
\hline 2 & 5 & 0.081 & 0.074 & 0.024 & 092 & 0.05100 & 0.0047 & 0.0052 & 015 & 0.0050 & 0.000028 \\
\hline 7 & 5 & $<0.003$ & 0.040 & 0.016 & $<0.014$ & $<0.00005$ & 0.0000 & 0.0026 & 0.0009 & 0.0000 & 0.000000 \\
\hline 3 & 11 & $<0.003$ & 6.196 & $<0.010$ & $<0.014$ & 0.00017 & 0.0000 & 0.4076 & 0.0000 & 0.0000 & 0.000009 \\
\hline 13 & 11 & $<0.003$ & 4.273 & $<0.010$ & $<0.014$ & 0.00034 & 0.0000 & 0.2648 & 0.0000 & 0.0000 & 0.000016 \\
\hline 14 & 19 & $<0.003$ & 1.454 & $<0.010$ & $<0.014$ & 0.00017 & 0.0000 & 0.0853 & 0.0000 & $0.0000^{\circ}$ & 0.000007 \\
\hline 6 & 19 & 0.020 & 0.880 & $<0.010$ & 0.020 & 0.14900 & 0.0009 & 0.0510 & 0.0000 & 0.0008 & 0.000063 \\
\hline 9 & 32 & $<0.003$ & 0.130 & 0.010 & $<0.014$ & $<0.00005$ & 0.0000 & 0.0078 & 0.0005 & 0.0000 & 0.000000 \\
\hline 15 & 32 & .003 & 0.061 & 23 & $<0.014$ & 0.00012 & 0.0000 & 0.0039 & 0.0013 & 0.0000 & 0.000006 \\
\hline \multicolumn{12}{|c|}{ MWFA grouts } \\
\hline 21 & 1 & 0.009 & 0.021 & 0.010 & 0.019 & 0.00069 & 0.0004 & 0.0014 & 0.0004 & 0.0007 & 0.000025 \\
\hline 26 & 1 & 0.006 & 0.010 & $<0.010$ & 0.015 & 0.00490 & 0.0002 & 0.0007 & 0.0000 & 0.0005 & 0.000179 \\
\hline 28 & 2 & $<0.003$ & 0.031 & $<0.010$ & $<0.014$ & 0.00010 & 0.0000 & 0.0024 & 0.0000 & 0.0000 & 0.000004 \\
\hline 23 & 2 & $<0.003$ & 0.513 & $<0.010$ & $<0.014$ & 0.00014 & 0.0000 & 0.0392 & 0.0000 & 0.0000 & 0.000006 \\
\hline 31 & 3 & $<0.003$ & 0.932 & $<0.010$ & $<0.014$ & 0.00022 & 0.0000 & 0.0593 & 0.0000 & 0.0000 & 0.000008 \\
\hline 20 & 3 & $<0.003$ & 1.247 & 0.010 & $<0.014$ & 0.00007 & 0.0000 & 0.0807 & 0.0004 & 0.0000 & 0.000002 \\
\hline 25 & 4 & $<0.003$ & 0.030 & $<0.010$ & $<0.014$ & 0.00047 & 0.0000 & 0.0024 & 0.0000 & 0.0000 & 0.000021 \\
\hline 30 & 4 & $<0.003$ & 0.011 & $<0.010$ & $<0.014$ & 0.00007 & 0.0000 & 0.0008 & 0.0000 & 0.0000 & 0.000003 \\
\hline 18 & 5 & $<0.003$ & $<0.006$ & $<0.010$ & $<0.014$ & 0.00006 & 0.0000 & 0.0000 & 0.0000 & 0.0000 & 0.000003 \\
\hline 22 & 5 & $<0.003$ & 0.011 & $<0.010$ & $<0.014$ & 0.00012 & 0.0000 & 0.0009 & 0.0000 & 0.0000 & 0.000005 \\
\hline 32 & 11 & $<0.003$ & 5.089 & $<0.010$ & $<0.014$ & 0.00031 & 0.0000 & 0.3994 & 0.0000 & 0.0000 & 0.000014 \\
\hline 19 & 11 & 0.108 & 4.336 & 0.510 & 0.210 & 0.00005 & 0.0048 & 0.3242 & 0.0253 & 0.0088 & 0.000002 \\
\hline 24 & 19 & $<0.003$ & 4.890 & $<0.010$ & $<0.014$ & 0.00061 & 0.0000 & 0.3546 & 0.0000 & 0.0000 & 0.000025 \\
\hline 29 & 19 & $<0.003$ & 4.613 & $<0.010$ & $<0.014$ & 0.00007 & 0.0000 & 0.3367 & 0.0000 & 0.0000 & 0.000003 \\
\hline 27 & 32 & $<0.003$ & 0.020 & $<0.010$ & $<0.014$ & 0.00006 & 0.0000 & 0.0014 & 0.0000 & 0.0000 & 0.000002 \\
\hline 17 & 32 & $<0.003$ & 0.429 & $<0.010$ & $<0.014$ & 0.00099 & 0.0000 & 0.0313 & 0.0000 & 0.0000 & 0.000041 \\
\hline
\end{tabular}


Table 14. Compositions of grouts made from the standard MWFA surrogate sludges using a dry blend of 90:10 slag cement ${ }^{a}$

\begin{tabular}{|c|c|c|c|c|c|c|c|c|c|c|}
\hline \multirow{3}{*}{ Test } & \multirow{3}{*}{$\begin{array}{c}\text { Nominal } \\
\text { standard } \\
\text { sludge } \\
\text { loading } \\
\text { (fraction) }\end{array}$} & \multicolumn{8}{|c|}{ Composition in the final grout (mass fraction) } & \multirow[b]{3}{*}{ W/S } \\
\hline & & \multirow{2}{*}{$\begin{array}{l}\text { Actual standard } \\
\text { sludge loading } \\
\text { (fraction) }\end{array}$} & \multirow[b]{2}{*}{ Dry blend } & \multirow[b]{2}{*}{ Added water } & \multirow{2}{*}{$\begin{array}{c}\text { Total wet } \\
\text { sludge loading } \\
\text { standard + } \\
\text { added water }\end{array}$} & \multicolumn{4}{|c|}{ Salts } & \\
\hline & & & & & & $\mathrm{NaCl}$ & $\mathrm{CaSO}_{4}$ & $\mathrm{NaNO}_{3}$ & Subtotal & \\
\hline \multicolumn{11}{|c|}{ Standard high-chloride MWFA surrogate sludge } \\
\hline 1 & 0.90 & 0.6766 & 0.0744 & 0.2489 & 0.9256 & 0.07 & 0.03 & & 0.10 & 0.81 \\
\hline 2 & 0.80 & 0.5493 & 0.1373 & 0.3134 & 0.8627 & 0.05 & 0.03 & & 0.08 & 0.91 \\
\hline 3 & 0.70 & 0.4904 & 0.2102 & 0.2995 & 0.7898 & 0.05 & 0.02 & & 0.07 & 0.80 \\
\hline 4 & 0.60 & 0.4199 & 0.2799 & 0.3002 & 0.7201 & 0.04 & 0.02 & & 0.06 & 0.74 \\
\hline 5 & 0.50 & 0.3581 & 0.3581 & 0.2838 & 0.6419 & 0.04 & 0.02 & & 0.05 & 0.64 \\
\hline \multicolumn{11}{|c|}{ Standard high-nitrate MWFA surrogate sludge } \\
\hline 6 & 0.90 & 0.7673 & 0.0847 & 0.1480 & 0.9153 & & & 0.46 & 0.46 & 0.34 \\
\hline 7 & 0.80 & 0.6892 & 0.1723 & 0.1385 & .0 .8277 & & & 0.41 & 0.41 & 0.31 \\
\hline 8 & 0.70 & 0.6076 & 0.2604 & 0.1319 & 0.7396 & & & 0.36 & 0.36 & 0.28 \\
\hline 9 & 0.60 & 0.5167 & 0.3445 & 0.1388 & 0.6555 & & & 0.31 & 0.31 & 0.26 \\
\hline 10 & 0.50 & 0.4276 & 0.4276 & 0.1447 & 0.5724 & & & 0.26 & 0.26 & 0.26 \\
\hline
\end{tabular}

The $\mathrm{pH}$ of the total wet sludge was adjusted to $z 12$ by adding $10 \mathrm{~N} \mathrm{NaOH}$ and testing with $\mathrm{pH}$ paper strips prior to mixing with the

90:10 slag:cement dry blend. 
Table 15. Performance testing results for the standard MWFA surrogate sludges

\begin{tabular}{|c|c|c|c|c|c|c|c|c|c|}
\hline \multirow[b]{2}{*}{ Test } & \multirow[b]{2}{*}{$\begin{array}{l}\text { Grout density } \\
\mathrm{g} / \mathrm{mL}\end{array}$} & \multicolumn{2}{|c|}{ Volume ratio grout/sludge } & \multirow[b]{2}{*}{$\begin{array}{c}\text { 28-d free } \\
\text { water (vol \%) }\end{array}$} & \multicolumn{5}{|c|}{ 28-d unconfined compressive strength (psi) } \\
\hline & & $\begin{array}{l}\text { Standard } \\
\text { surrogate } \\
\text { sludge } \\
\end{array}$ & $\begin{array}{c}\text { Total wet sludge } \\
\text { standard + added } \\
\text { water }\end{array}$ & & 1 & 2 & 3 & Average & $\begin{array}{l}\text { Standard } \\
\text { deviation }\end{array}$ \\
\hline \multicolumn{10}{|c|}{ Standard high-chloride MWFA surrogate sludge } \\
\hline 1 & 1.53 & 0.50 & 1.03 & 0.00 & 578 & 479 & 550 & 535 & 42 \\
\hline 2 & 1.50 & 0.63 & 1.06 & 0.00 & 641 & 664 & 647 & 651 & 10 \\
\hline 3 & 1.56 & 0.68 & 1.10 & 0.00 & 1,074 & 1,072 & 1,108 & 1,085 & 16 \\
\hline 4 & 1.56 & 0.80 & 1.19 & 0.00 & 1,599 & 1,430 & 1,536 & 1,522 & 70 \\
\hline 5 & 1.63 & 0.89 & 1.26 & 0.00 & 2,215 & 2,118 & 2,185 & 2,173 & 41 \\
\hline \multicolumn{10}{|c|}{ Standard high-nitrate MWFA surrogate sludge } \\
\hline 6 & 1.76 & 0.39 & 1.06 & 0.00 & 210 & 260 & 218 & 230 & 22 \\
\hline 7 & 1.80 & 0.42 & 1.13 & 0.00 & 995 & 1,065 & 1,036 & 1,032 & 29 \\
\hline 8 & 1.86 & 0.46 & 1.22 & 0.00 & 1,973 & 2,075 & 1,945 & 1,998 & 56 \\
\hline 9 & 1.99 & 0.51 & 1.25 & 0.00 & 2,973 & 3,068 & 3,120 & 3,053 & 61 \\
\hline 10 & 1.60 & 0.76 & 1.72 & 0.00 & 3,858 & 3,513 & 3,253 & 3,541 & 248 \\
\hline
\end{tabular}


Table 16. TCLP performance of the standard MWFA surrogate sludges

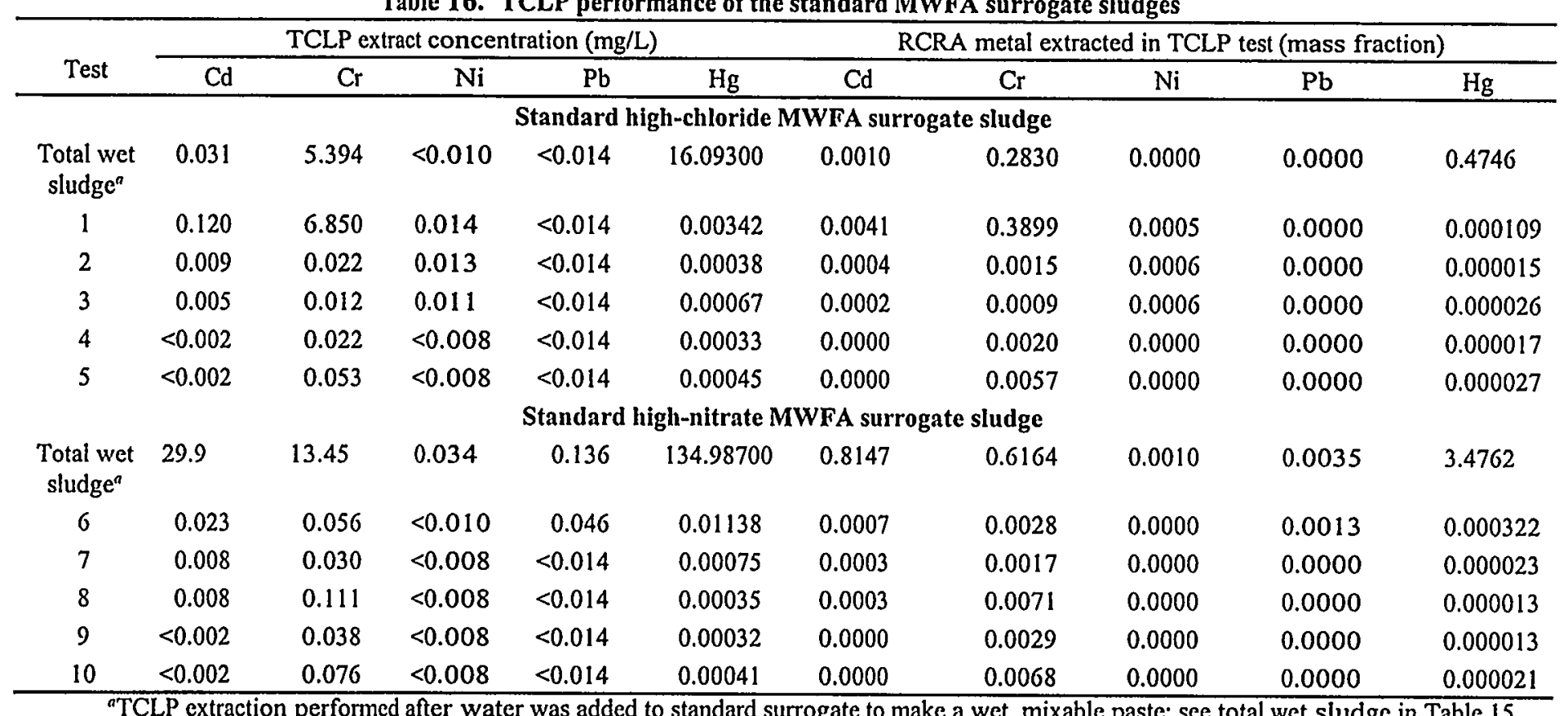

"TCLP extraction performed after water was added to standard surrogate to make a wet, mixable paste; see total wet sludge in Table 15 . 
Table 17. Standard MWFA surrogate sludge grouts put on the same compositional basis as that listed for the statistical-design grouts

\begin{tabular}{|c|c|c|c|c|c|c|c|c|c|c|c|c|c|}
\hline \multirow{5}{*}{ Test } & \multicolumn{12}{|c|}{ Composition in the final grout (mass fraction) } & \multirow{5}{*}{ W/S } \\
\hline & \multirow{4}{*}{$\begin{array}{l}\text { Waste } \\
\text { solids }\end{array}$} & \multicolumn{7}{|c|}{ Wet sludge } & \multicolumn{4}{|c|}{ Dry blend } & \\
\hline & & \multirow{3}{*}{ Water" } & \multirow{3}{*}{$\begin{array}{c}\text { Wet } \\
\text { sludge }\end{array}$} & \multicolumn{6}{|c|}{ Salts } & \multirow{3}{*}{ Cement $^{b}$} & \multirow{3}{*}{ Slag } & \multirow{3}{*}{ Subtotal } & \\
\hline & & & & \multirow[b]{2}{*}{$\mathrm{CaSO}_{4}$} & \multirow[b]{2}{*}{$\mathrm{NaCl}$} & \multicolumn{3}{|c|}{$\mathrm{NaNO}_{3}$} & \multirow[b]{2}{*}{ Subtotal } & & & & \\
\hline & & & & & & in $\mathrm{ECM}$ & Added & Subtotal & & & & & \\
\hline \multicolumn{14}{|c|}{ Standard high-chloride MWFA surrogate sludge } \\
\hline 1 & 0.45 & 0.45 & 0.90 & 0.03 & 0.07 & 0.00 & 0.00 & 0.00 & 0.10 & 0.04 & 0.07 & 0.10 & 0.81 \\
\hline 3 & 0.33 & 0.44 & 0.77 & 0.02 & 0.05 & 0.00 & 0.00 & 0.00 & 0.07 & 0.04 & 0.19 & 0.23 & 0.80 \\
\hline 4 & 0.28 & 0.42 & 0.70 & 0.02 & 0.04 & 0.00 & 0.00 & 0.00 & 0.06 & 0.05 & 0.25 & 0.30 & 0.74 \\
\hline 5 & 0.24 & 0.39 & 0.63 & 0.02 & 0.04 & 0.00 & 0.00 & 0.00 & 0.05 & 0.05 & 0.32 & 0.37 & 0.64 \\
\hline \multicolumn{14}{|c|}{ Standard high-nitrate MWFA surrogate sludge } \\
\hline 6 & 0.65 & 0.25 & 0.90 & 0.00 & 0.00 & 0.00 & 0.46 & 0.46 & 0.46 & 0.02 & 0.08 & 0.10 & 0.34 \\
\hline 10 & 0.36 & 0.20 & 0.57 & 0.00 & 0.00 & 0.00 & 0.26 & 0.26 & 0.26 & 0.05 & 0.38 & 0.43 & 0.26 \\
\hline
\end{tabular}

${ }^{b}$ Includes cement in the standard surrogate and cement added with slag as a 90:10 slag:cement mix. 
Table 18. Additional data for the wet-sludge makeup for the grouts made from the standard MWFA surrogates

\begin{tabular}{|c|c|c|c|c|c|c|c|c|c|c|c|c|}
\hline \multirow{3}{*}{ Test } & \multicolumn{7}{|c|}{ Composition in the final grout (mass fraction) } & \multicolumn{5}{|c|}{$\begin{array}{l}\text { RCRA compound concentration in waste } \\
\text { solids ( } \mathrm{mg} / \mathrm{kg} \text { ) }\end{array}$} \\
\hline & \multirow{2}{*}{$\begin{array}{l}\text { Wet ECM } \\
\text { sludge }\end{array}$} & \multicolumn{6}{|c|}{ MWFA other solids } & \multirow[b]{2}{*}{$\mathrm{PbO}$} & \multirow[b]{2}{*}{$\mathrm{CrO}_{3}$} & \multirow[b]{2}{*}{$\mathrm{HgO}$} & \multirow[b]{2}{*}{$\mathrm{CdO}$} & \multirow[b]{2}{*}{$\mathrm{NiO}$} \\
\hline & & $\mathrm{Fe}_{2} \mathrm{O}_{3}$ & $\mathrm{Al}(\mathrm{OH})_{3}$ & $\mathrm{Na}_{3} \mathrm{PO}_{4} \cdot 12 \mathrm{H}_{2} \mathrm{O}$ & $\mathrm{Mg}(\mathrm{OH})_{2}$ & $\mathrm{CaSiO}_{3}$ & Subtotal & & & & & \\
\hline \multicolumn{13}{|c|}{ Standard high-nitrate MWFA surrogate sludge } \\
\hline 1 & 0.00 & 0.09 & 0.06 & 0.03 & 0.06 & 0.11 & 0.34 & 1503 & 1506 & 1504 & 1504 & 1503 \\
\hline 2 & 0.00 & 0.07 & 0.05 & 0.02 & 0.05 & 0.09 & 0.28 & 1511 & 1511 & 1509 & 1510 & 1508 \\
\hline 3 & 0.00 & 0.06 & 0.04 & 0.02 & 0.04 & 0.08 & 0.25 & 1501 & 1507 & 1717 & 1504 & 1504 \\
\hline 4 & 0.00 & 0.05 & 0.04 & 0.02 & 0.04 & 0.07 & 0.21 & 1506 & 1505 & 1505 & 1507 & 1507 \\
\hline 5 & 0.00 & 0.05 & 0.03 & 0.02 & 0.03 & 0.06 & 0.18 & 1504 & 1509 & 1501 & 1502 & 1502 \\
\hline \multicolumn{13}{|c|}{ Standard high-nitrate MWFA surrogate sludge } \\
\hline 6 & 0.00 & 0.05 & 0.03 & 0.02 & 0.03 & 0.06 & 0.18 & 1185 & 1184 & 1183 & 1183 & 1183 \\
\hline 7 & 0.00 & 0.04 & 0.03 & 0.01 & 0.03 & 0.06 & 0.17 & 1183 & 1183 & 1184 & 1183 & 1182 \\
\hline 8 & 0.00 & 0.04 & 0.02 & 0.01 & 0.02 & 0.05 & 0.15 & 1184 & 1183 & 1186 & 1183 & 1185 \\
\hline 9 & 0.00 & 0.03 & 0.03 & 0.01 & 0.02 & 0.04 & 0.13 & 1164 & 1165 & 1166 & 1165 & 1160 \\
\hline 10 & 0.00 & 0.03 & 0.02 & 0.01 & 0.02 & 0.03 & 0.10 & 1184 & 1183 & 1182 & 1184 & 1182 \\
\hline
\end{tabular}


Table 19. Final compositions of the grouts with high chloride and sulfate loadings ${ }^{a}$

\begin{tabular}{|c|c|c|c|c|c|c|c|c|c|c|c|c|c|}
\hline \multirow{5}{*}{ Test } & \multicolumn{12}{|c|}{ Composition in the final grout (mass fraction) } & \multirow{5}{*}{ W/S } \\
\hline & & \multirow[b]{4}{*}{ Water } & & \multicolumn{4}{|c|}{ Wet sludge } & & & \multicolumn{3}{|c|}{ Dry blend } & \\
\hline & \multirow{3}{*}{$\begin{array}{l}\text { Waste } \\
\text { solids }\end{array}$} & & \multirow{3}{*}{$\begin{array}{l}\text { Wet } \\
\text { sludge }\end{array}$} & \multicolumn{6}{|c|}{ Salts } & \multirow[b]{3}{*}{ Cement } & \multirow{3}{*}{ Slag } & \multirow{3}{*}{ Subtotal } & \\
\hline & & & & \multirow[b]{2}{*}{$\mathrm{CaSO}_{4}$} & \multirow[b]{2}{*}{$\mathrm{NaCl}$} & \multicolumn{3}{|c|}{$\mathrm{NaNO}_{3}$} & \multirow[b]{2}{*}{ Subtotal } & & & & \\
\hline & & & & & & in ECM & Added & $\overline{\text { Subtotal }}$ & & & & & \\
\hline & & & & & & Sodium & hloride & & & & & & \\
\hline 1 & 0.50 & 0.25 & 0.75 & 0.00 & 0.10 & 0.00 & 0.00 & 0.00 & 0.10 & 0.03 & 0.22 & 0.25 & 0.33 \\
\hline 3 & 0.50 & 0.25 & 0.75 & 0.00 & 0.30 & 0.00 & 0.00 & 0.00 & 0.30 & 0.03 & 0.22 & 0.25 & 0.33 \\
\hline 4 & 0.50 & 0.25 & 0.75 & 0.00 & 0.40 & 0.00 & 0.00 & 0.00 & 0.40 & 0.03 & 0.23 & 0.25 & 0.33 \\
\hline 5 & 0.50 & 0.25 & 0.75 & 0.00 & 0.50 & 0.00 & 0.00 & 0.00 & 0.50 & 0.03 & 0.22 & 0.25 & 0.33 \\
\hline & & & & & & Calciun & sulfate & & & & & & \\
\hline 6 & 0.50 & 0.25 & 0.75 & 0.10 & 0.00 & 0.00 & 0.00 & 0.00 & 0.10 & 0.03 & 0.22 & 0.25 & 0.33 \\
\hline 10 & 0.49 & 0.27 & 0.76 & 0.48 & 0.00 & 0.00 & 0.00 & 0.00 & 0.48 & 0.02 & 0.22 & 0.24 & 0.37 \\
\hline
\end{tabular}

0.10 slag. 
Table 20. Additional data for the wet-sludge makeup for the grouts prepared with high-chloride and high-sulfate loadings

\begin{tabular}{|c|c|c|c|c|c|c|c|c|c|c|c|c|}
\hline \multirow{3}{*}{ Test } & \multicolumn{7}{|c|}{ Composition in the final grout (mass fraction) } & \multicolumn{5}{|c|}{$\begin{array}{l}\text { RCRA compound concentration in waste solids } \\
\qquad(\mathrm{mg} / \mathrm{kg})\end{array}$} \\
\hline & \multirow{2}{*}{$\begin{array}{c}\text { Wet ECM } \\
\text { Sludge }\end{array}$} & \multicolumn{6}{|c|}{ MWFA other solids } & \multirow{2}{*}{$\mathrm{PbO}$} & \multirow{2}{*}{$\mathrm{CrO}_{3}$} & \multirow{2}{*}{$\mathrm{HgO}$} & \multirow{2}{*}{$\mathrm{CdO}$} & \multirow{2}{*}{$\mathrm{NiO}$} \\
\hline & & $\mathrm{Fe}_{2} \mathrm{O}_{3}$ & $\mathrm{Al}(\mathrm{OH})_{3}$ & $\mathrm{Na}_{3} \mathrm{PO}_{4} \cdot 12 \mathrm{H}_{2} \mathrm{O}$ & $\mathrm{Mg}(\mathrm{OH})_{2}$ & $\mathrm{CaSiO}_{3}$ & Subtotal & & & & & \\
\hline \multicolumn{13}{|c|}{ Sodium chloride } \\
\hline 1 & 0.00 & 0.10 & 0.07 & 0.03 & 0.07 & 0.13 & 0.40 & 1505 & 1501 & 1501 & 1499 & 1499 \\
\hline 2 & 0.00 & 0.07 & 0.05 & 0.02 & 0.05 & 0.10 & 0.30 & 1502 & 1500 & 1500 & 1500 & 1499 \\
\hline 3 & 0.00 & 0.05 & 0.03 & 0.02 & 0.03 & 0.07 & 0.20 & 1498 & 1498 & 1497 & 1497 & 1500 \\
\hline 4 & 0.00 & 0.02 & 0.02 & 0.01 & 0.02 & 0.03 & 0.09 & 1507 & 1510 & 1507 & 1507 & 1509 \\
\hline 5 & 0.00 & 0.00 & 0.00 & 0.00 & 0.00 & 0.00 & 0.00 & 1501 & 1504 & 1500 & 1500 & 1501 \\
\hline \multicolumn{13}{|c|}{ Calcium sulfate } \\
\hline 6 & 0.00 & 0.10 & 0.07 & 0.03 & 0.07 & 0.13 & 0.40 & 1501 & 1501 & 1502 & 1498 & 1499 \\
\hline 7 & 0.00 & 0.07 & 0.05 & 0.02 & 0.05 & 0.10 & 0.29 & 1499 & 1500 & 1499 & 1499 & 1498 \\
\hline 8 & 0.00 & 0.05 & 0.03 & 0.02 & 0.03 & 0.06 & 0.19 & 1502 & 1501 & 1497 & 1502 & 1497 \\
\hline 9 & 0.00 & 0.02 & 0.02 & 0.01 & 0.02 & 0.03 & 0.09 & 1500 & 1499 & 1500 & 1498 & 1501 \\
\hline 10 & 0.00 & 0.00 & 0.00 & 0.00 & 0.00 & 0.00 & 0.00 & 1500 & 1500 & 1501 & 1500 & 1500 \\
\hline
\end{tabular}


Table 21. Performance testing results testing high-chloride and high-sulfate loadings

\begin{tabular}{|c|c|c|c|c|c|c|c|c|}
\hline \multirow[b]{2}{*}{ Test } & \multirow{2}{*}{$\begin{array}{l}\text { Grout density } \\
\qquad(\mathrm{g} / \mathrm{mL})\end{array}$} & \multirow{2}{*}{$\begin{array}{l}\text { Grout/sludge } \\
\text { volume ratio }\end{array}$} & \multirow{2}{*}{$\begin{array}{l}\text { 28-d free } \\
\text { water (mass } \\
\text { fraction) }\end{array}$} & \multicolumn{5}{|c|}{ 28-d unconfined conpressive strength (psi) } \\
\hline & & & & 1 & 2 & 3 & Average & $\begin{array}{l}\text { Standard } \\
\text { Deviation }\end{array}$ \\
\hline \multicolumn{9}{|c|}{ Sodium chloride } \\
\hline 1 & 1.89 & 1.19 & 0.0000 & 2,485 & 2,265 & 2,173 & 1,672 & 775 \\
\hline 2 & 1.85 & 1.20 & 0.0000 & 1,940 & 1,910 & 1,760 & 1,499 & 603 \\
\hline 3 & 1.85 & 1.17 & 0.0000 & 1,428 & 1,370 & 1,420 & 1,406 & 26 \\
\hline 4 & 1.82 & 1.16 & 0.0000 & 788 & 750 & 778 & 772 & 16 \\
\hline 5 & 1.79 & 1.17 & 0.0000 & 880 & 984 & 952 & 939 & 43 \\
\hline \multicolumn{9}{|c|}{ Calcium sulfate } \\
\hline 6 & 1.91 & 1.20 & 0.0000 & 3,510 & 3,723 & 3,793 & 2,575 & 1,672 \\
\hline 7 & 1.93 & 1.15 & 0.0000 & 3,708 & 3,610 & 3,373 & 3,563 & 141 \\
\hline 8 & 1.87 & 1.17 & 0.0000 & 4,320 & 4,155 & 4,558 & 4,344 & 165 \\
\hline 9 & 1.89 & 1.16 & 0.0000 & 5,280 & 5,068 & 5,383 & 5,243 & 131 \\
\hline 10 & 1.88 & 1.17 & 0.0000 & 5,608 & 5,353 & 5,690 & 5,550 & 144 \\
\hline
\end{tabular}


Table 22. TCLP performance test results for high-chloride and high-sulfate loadings

\begin{tabular}{|c|c|c|c|c|c|c|c|c|c|c|}
\hline \multirow[b]{2}{*}{ Test } & \multicolumn{5}{|c|}{ TCLP extract concentration $(\mathrm{mg} / \mathrm{L})$} & \multicolumn{5}{|c|}{ RCRA metal extracted in TCLP test (mass fraction) } \\
\hline & $\mathrm{Cd}$ & $\mathrm{Cr}$ & $\mathrm{Ni}$ & $\mathrm{Pb}$ & $\mathrm{Hg}$ & $\mathrm{Cd}$ & $\mathrm{Cr}$ & $\mathrm{Ni}$ & $\mathrm{Pb}$ & $\mathrm{Hg}$ \\
\hline & \multicolumn{9}{|c|}{ Sodium chloride } & · \\
\hline 1 & $<0.002$ & 0.036 & $<0.008$ & $<0.014$ & 0.00050 & 0.0000 & 0.0018 & 0.0000 & 0.0000 & 0.00001 \\
\hline 2 & $<0.002$ & 0.022 & $<0.008$ & $<0.014$ & 0.00043 & 0.0000 & 0.0011 & 0.0000 & 0.0000 & 0.00001 \\
\hline 3 & 0.008 & 0.021 & $<0.008$ & $<0.014$ & 0.00041 & 0.0002 & 0.0011 & 0.0000 & 0.0000 & 0.00001 \\
\hline 4 & 0.012 & 0.038 & $<0.008$ & $<0.014$ & 0.00038 & 0.0004 & 0.0019 & 0.0000 & 0.0000 & 0.00001 \\
\hline 5 & 0.018 & 0.035 & $<0.008$ & 0.014 & 0.00531 & 0.0005 & 0.0018 & 0.0000 & 0.0004 & 0.00015 \\
\hline \multicolumn{11}{|c|}{ Calcium sulfate } \\
\hline 6 & $<0.002$ & 0.041 & $<0.008$ & $<0.014$ & 0.00035 & 0.0000 & 0.0021 & 0.0000 & 0.0000 & 0.00001 \\
\hline 7 & 0.007 & 0.036 & $<0.008$ & $<0.014$ & 0.00059 & 0.0002 & 0.0019 & 0.0000 & 0.0000 & 0.00002 \\
\hline 8 & 0.007 & 0.026 & $<0.008$ & $<0.014$ & 0.00143 & 0.0002 & 0.0014 & 0.0000 & 0.0000 & 0.00004 \\
\hline 9 & 0.006 & 0.021 & $<0.008$ & $<0.014$ & 0.00047 & 0.0002 & 0.0011 & 0.0000 & 0.0000 & 0.00001 \\
\hline 10 & 0.014 & 0.655 & 0.010 & 0.020 & 0.00062 & 0.0004 & 0.0345 & 0.0003 & 0.0006 & 0.00002 \\
\hline
\end{tabular}



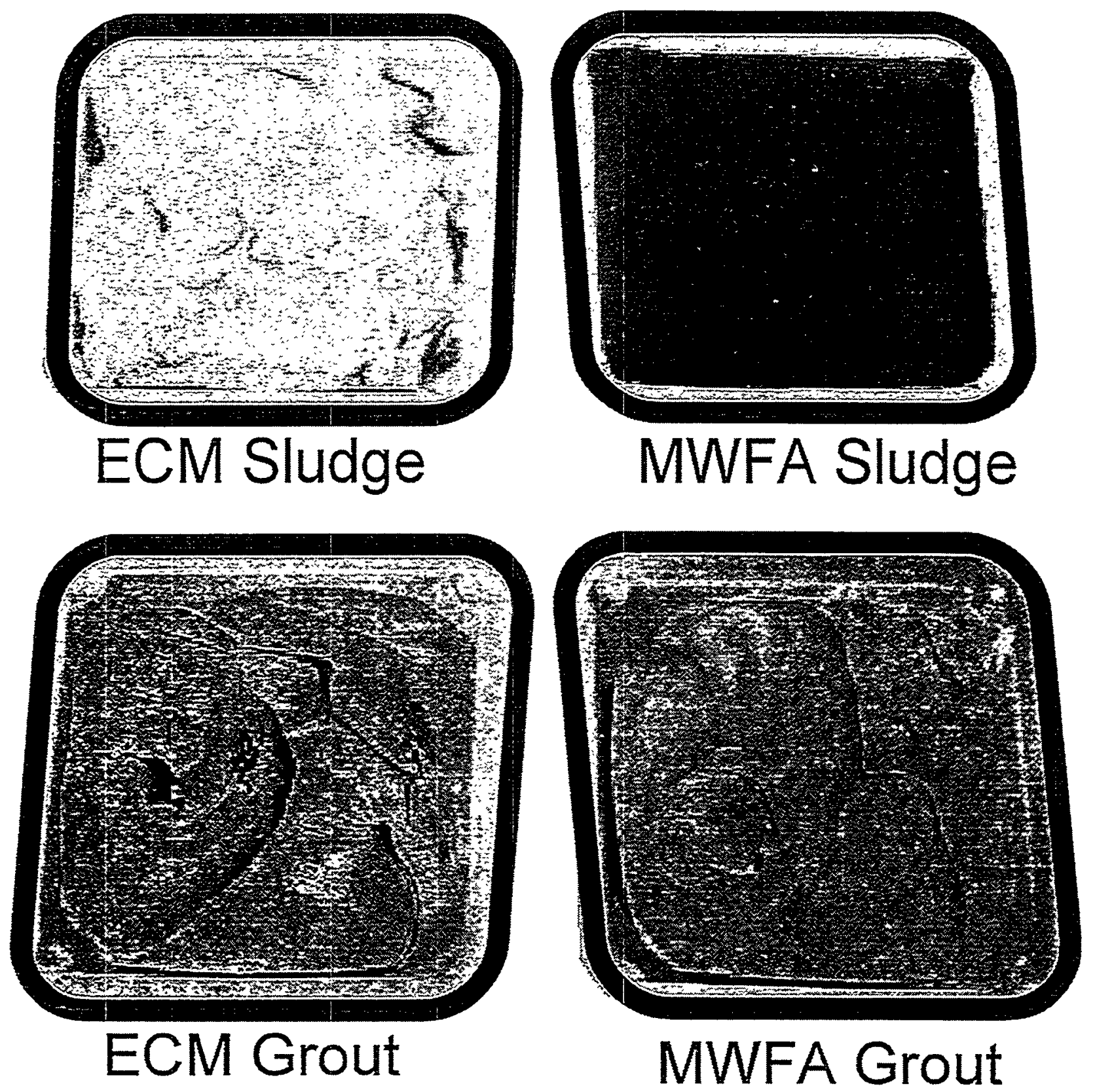

Fig. 1. Wet ECM sludge and wet sludge made from MWFA components with the typical grouts prepared from these sludges. 
ORNL DWG 98C-118

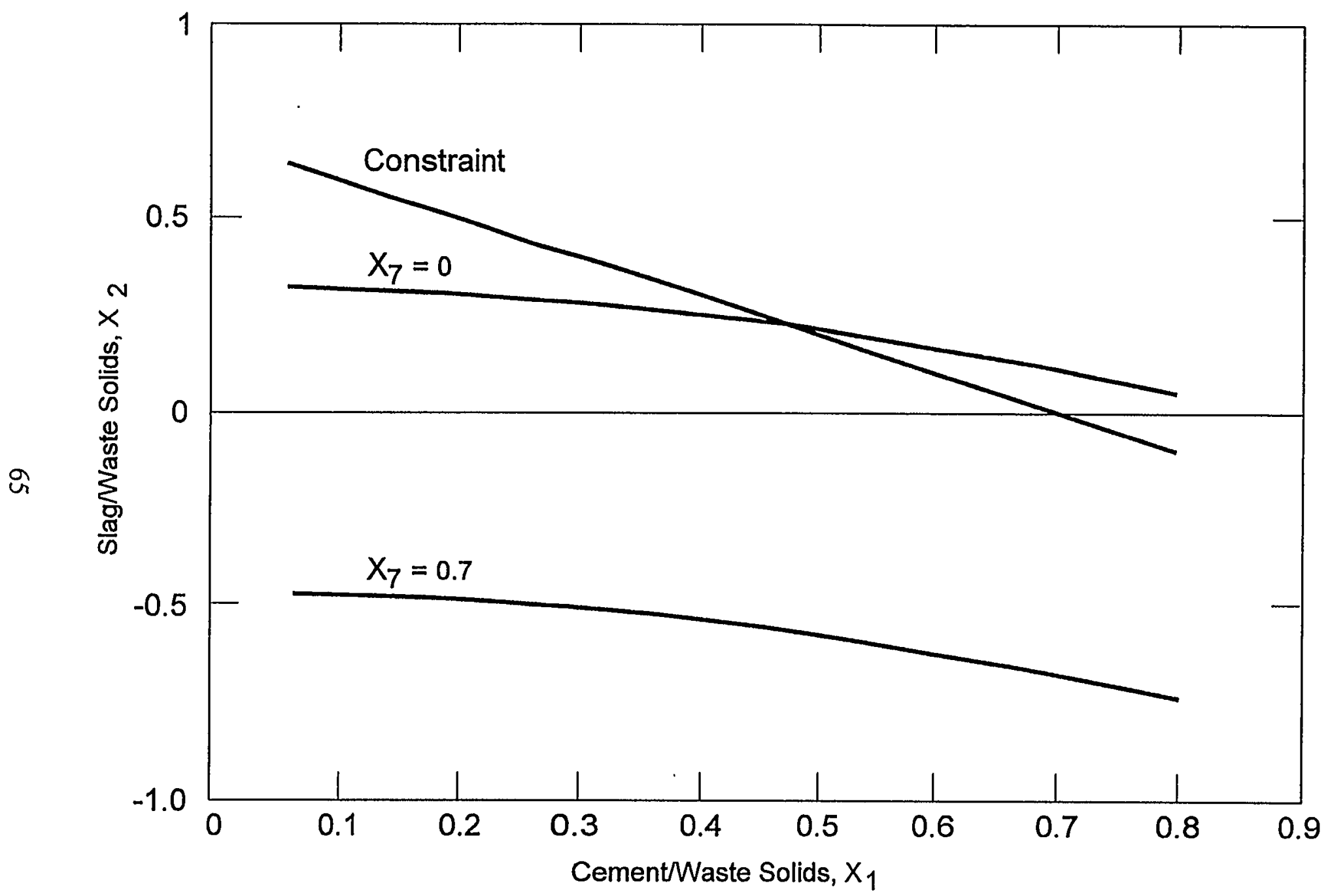

Fig. 2. Contour lines of 500-psi compressive strength for preliminary model of initial design. 


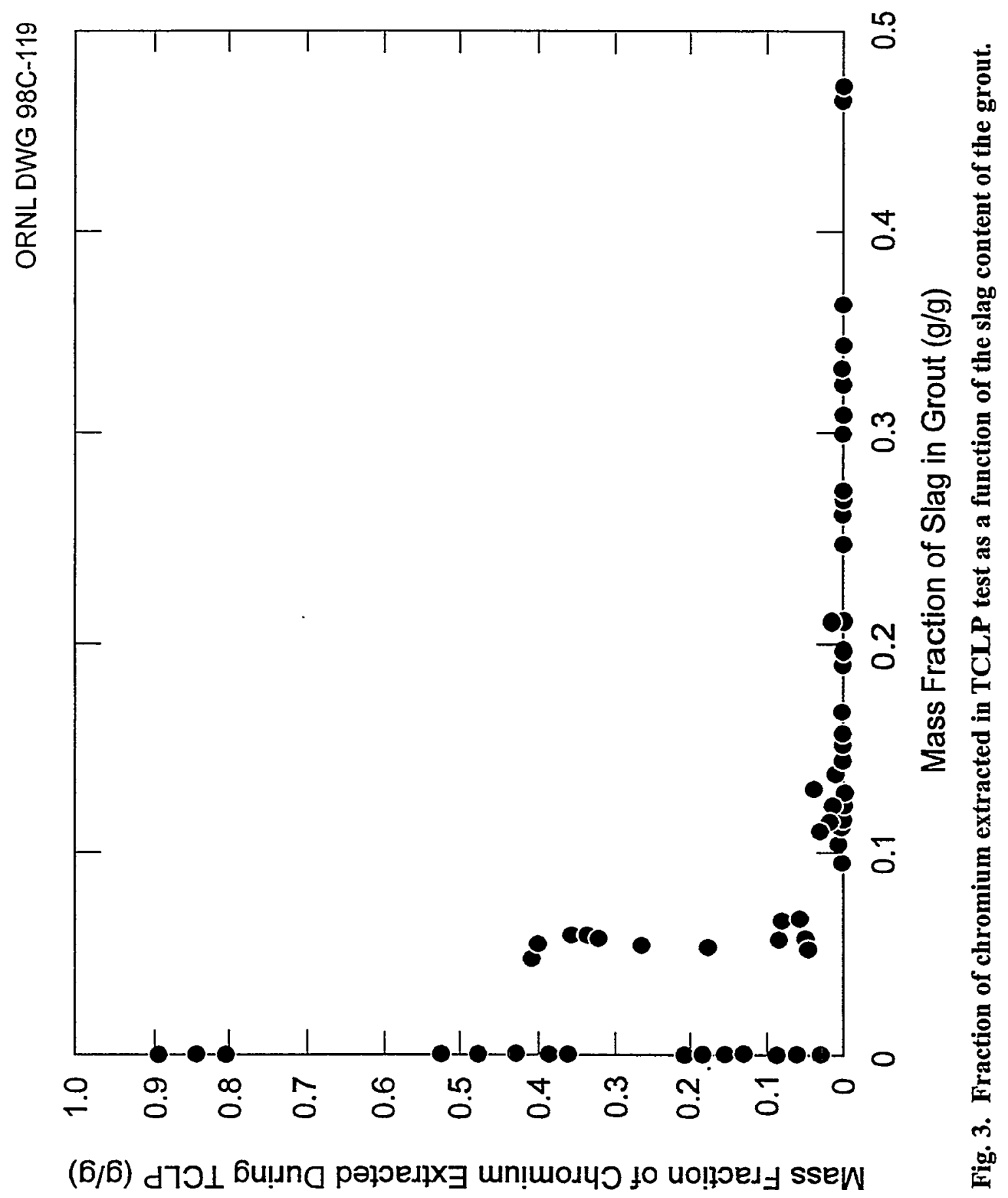




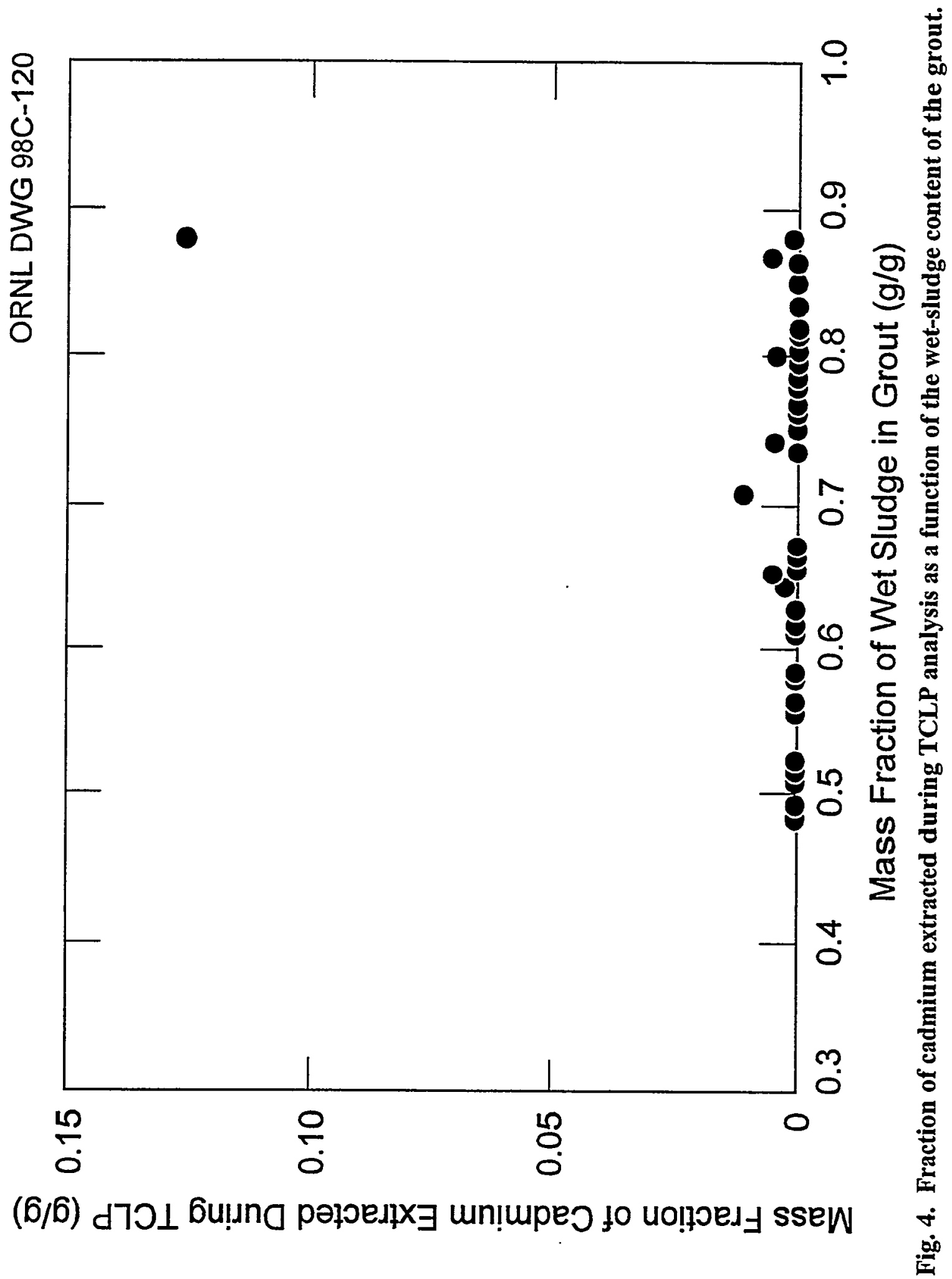


ORNL DWG 98C-121

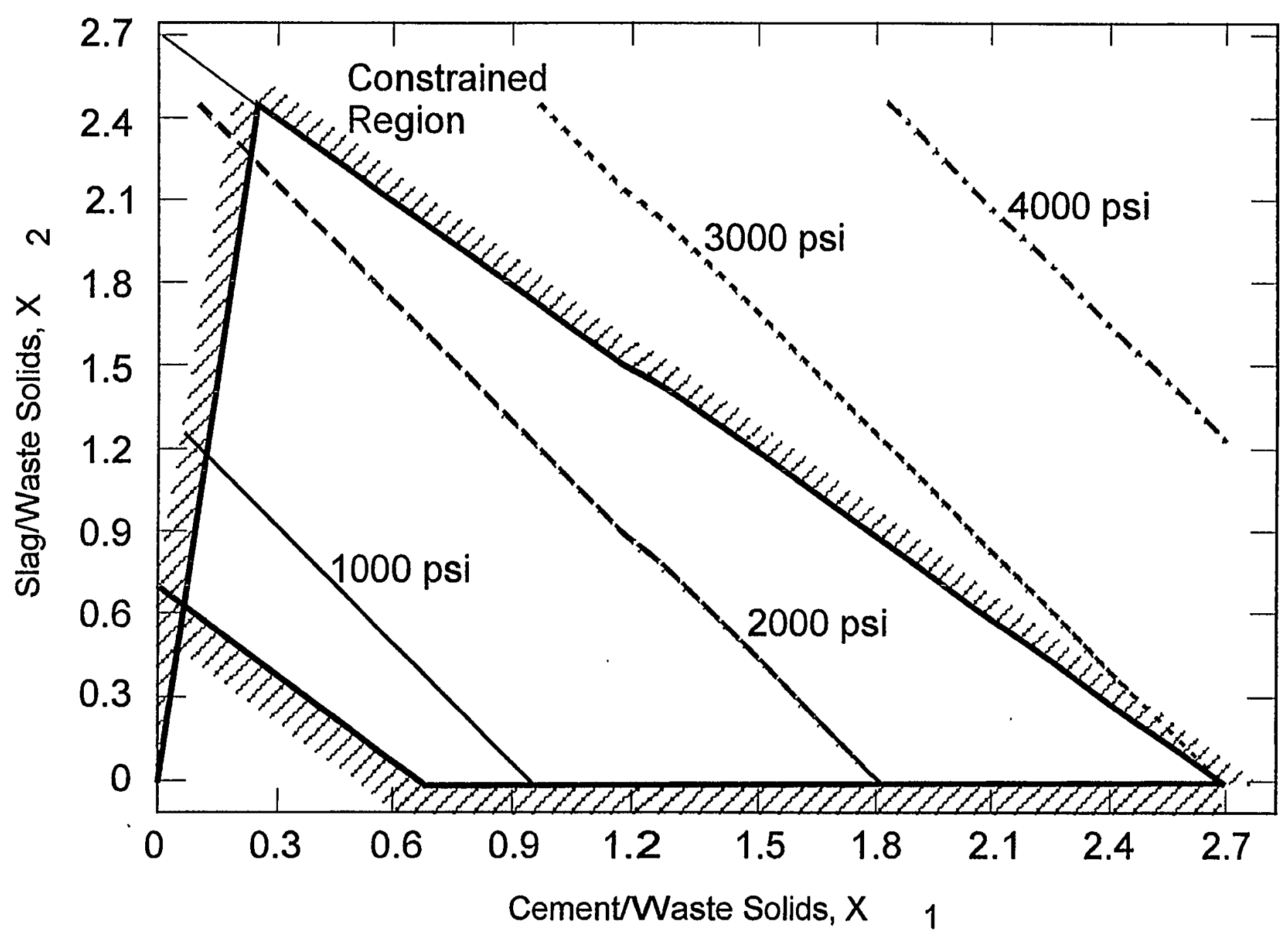

Fig. 5. Contour plots of average unconfined compressive strength for the recommended model from the initial design $\left(x_{3}=0.21, x_{5}=0, x_{6}=0, x_{7}=0.4, x_{8}=-1\right)$ 


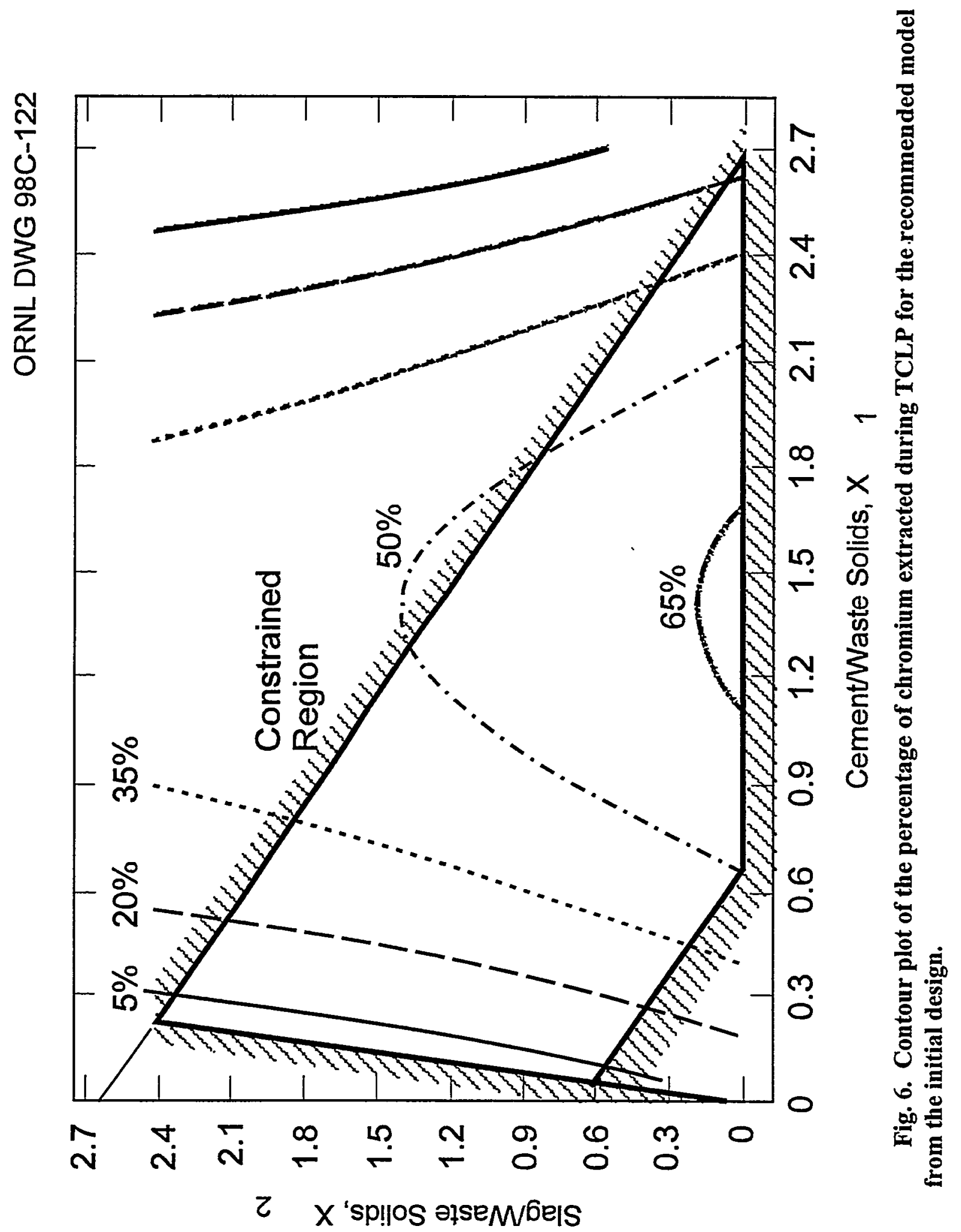




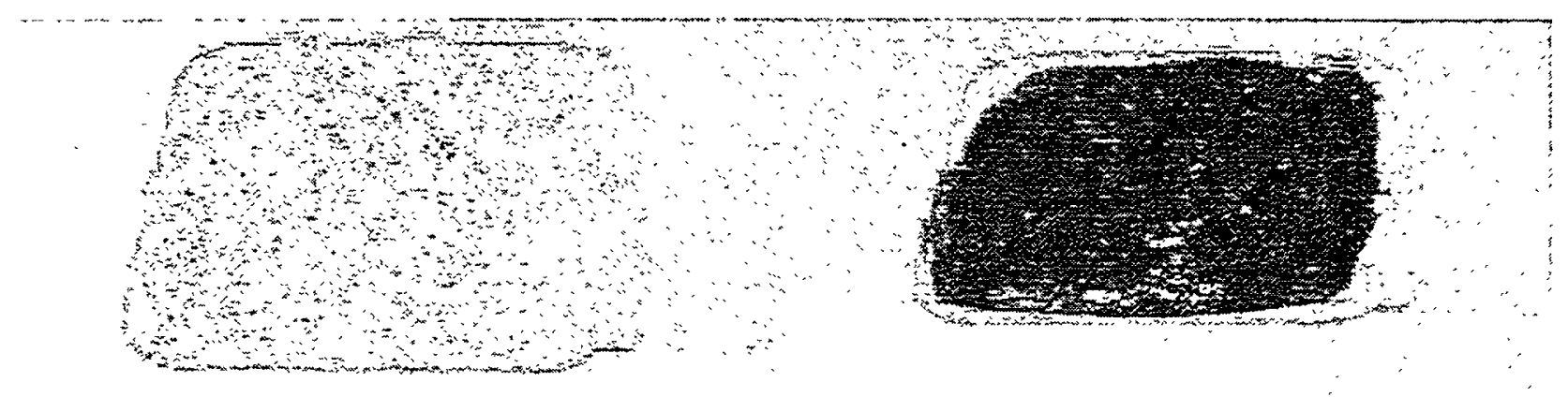

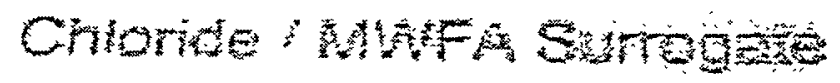

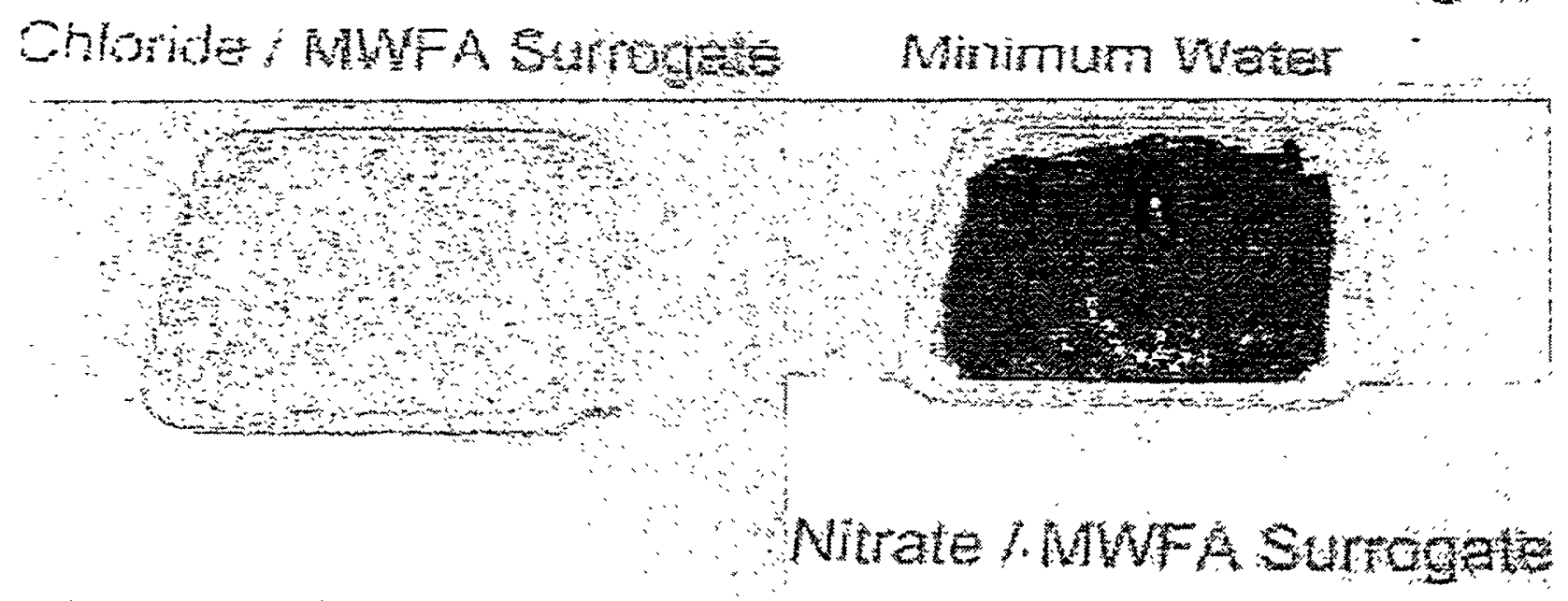
Nitrate/MWFA Surogate Mimum Water

Fig. 7. MWFA surrogate sludges with the standard water content from Table 2 and with the miniraum amount of water added to make a wet, mixable paste. 


\section{Appendix A}

STATISTICAL PRINTOUTS FOR REGRESSION ANALYSIS OF THE UNCONFINED COMPRESSIVE STRENGTHS FROM THE INITIAL DESIGN, DELETING THE ZERO STRENGTHS AND RUN 23 

Best Subsets Regression

Response is Averucs

46 cases used 1 cases contain missing values.

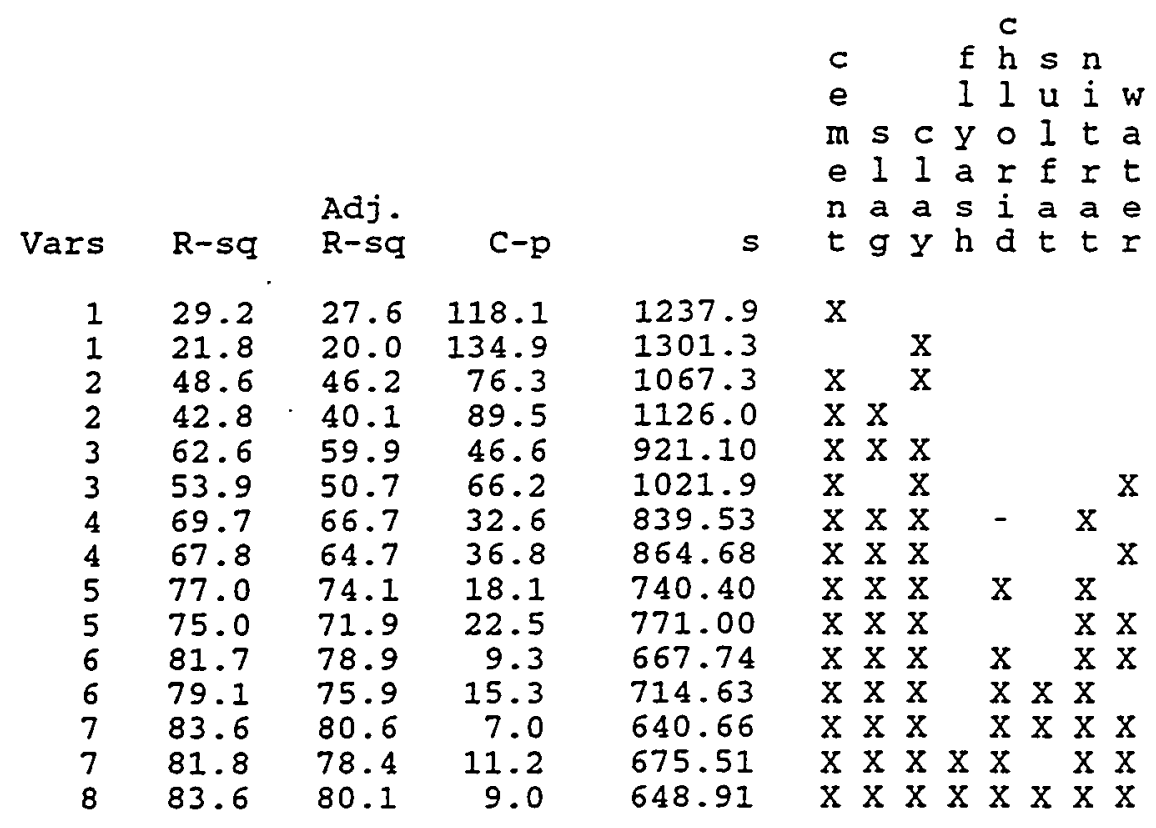




\section{Response Surface Regression}

$\begin{array}{lrrrr}\text { Estimated Regression Coefficients } & \text { for AverUCS } \\ \text { Term } & \text { Coef } & \text { Stdev } & \text { t-ratio } & \text { p } \\ \text { Constant } & -526 & 343.71 & -1.530 & 0.134 \\ \text { cement } & 1153 & 107.58 & 10.716 & 0.000 \\ \text { slag } & 806 & 123.26 & 6.542 & 0.000 \\ \text { clay } & -3523 & 485.84 & -7.252 & 0.000 \\ \text { chlorid } & 3693 & 828.21 & 4.458 & 0.000 \\ \text { sulfat } & 1747 & 836.25 & 2.090 & 0.043 \\ \text { nitrat } & 2151 & 414.95 & 5.184 & 0.000 \\ \text { water } & -309 & 95.35 & -3.244 & 0.002\end{array}$

$$
S=640.7 \quad R-s q=83.68 \quad R-s q(\text { adj })=80.6 \%
$$

Analysis of Variance for Averucs

$\begin{array}{lrrrrrr}\text { Source } & \text { DF } & \text { Seq SS } & \text { Adj SS } & \text { Adj MS } & \text { F } & \text { P } \\ \text { Regression } & 7 & 79642744 & 79642744 & 11377535 & 27.72 & 0.000 \\ \quad \text { Linear } & 7 & 79642744 & 79642744 & 11377535 & 27.72 & 0.000 \\ \text { Residual Error } & 38 & 15596853 & 15596853 & 410444 & & \\ \quad \text { Lack-of-Fit } & 22 & 12948005 & 12948005 & 588546 & 3.56 & 0.006 \\ \quad \text { Pure Error } & 16 & 2648848 & 2648848 & 165553 & & \\ \text { Total } & 45 & 95239600 & & & & \end{array}$

Unusual Observations for Averucs

$\begin{array}{rrrrrr}\text { Obs. Averucs } & \text { Fit } & \text { Stdev.Fit } & \text { Residual } & \text { St.Resid } \\ 26 & 4697.500 & 3396.604 & 294.717 & 1300.896 & 2.29 \mathrm{R}\end{array}$

$R$ denotes an obs. with a large st. resid. 


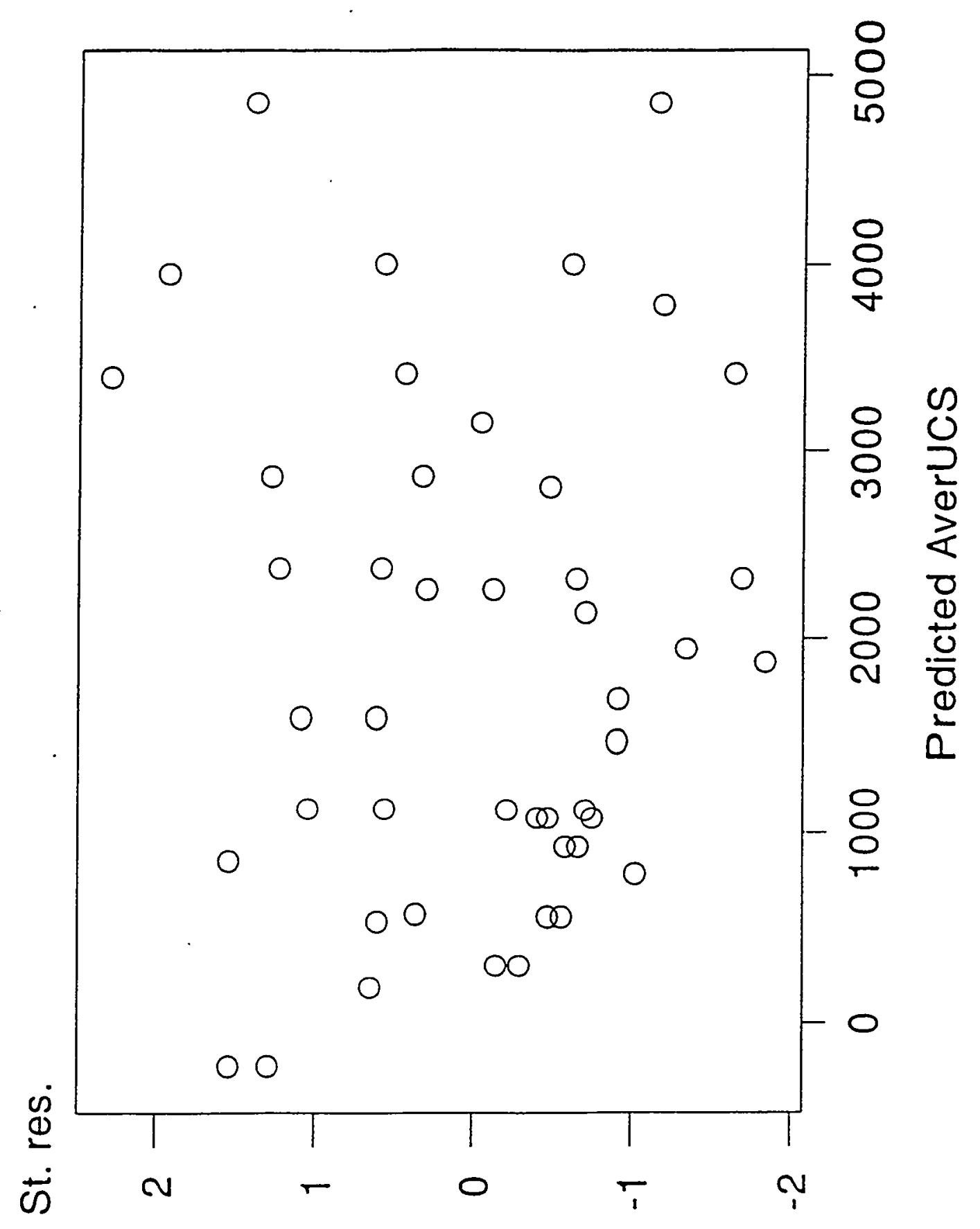




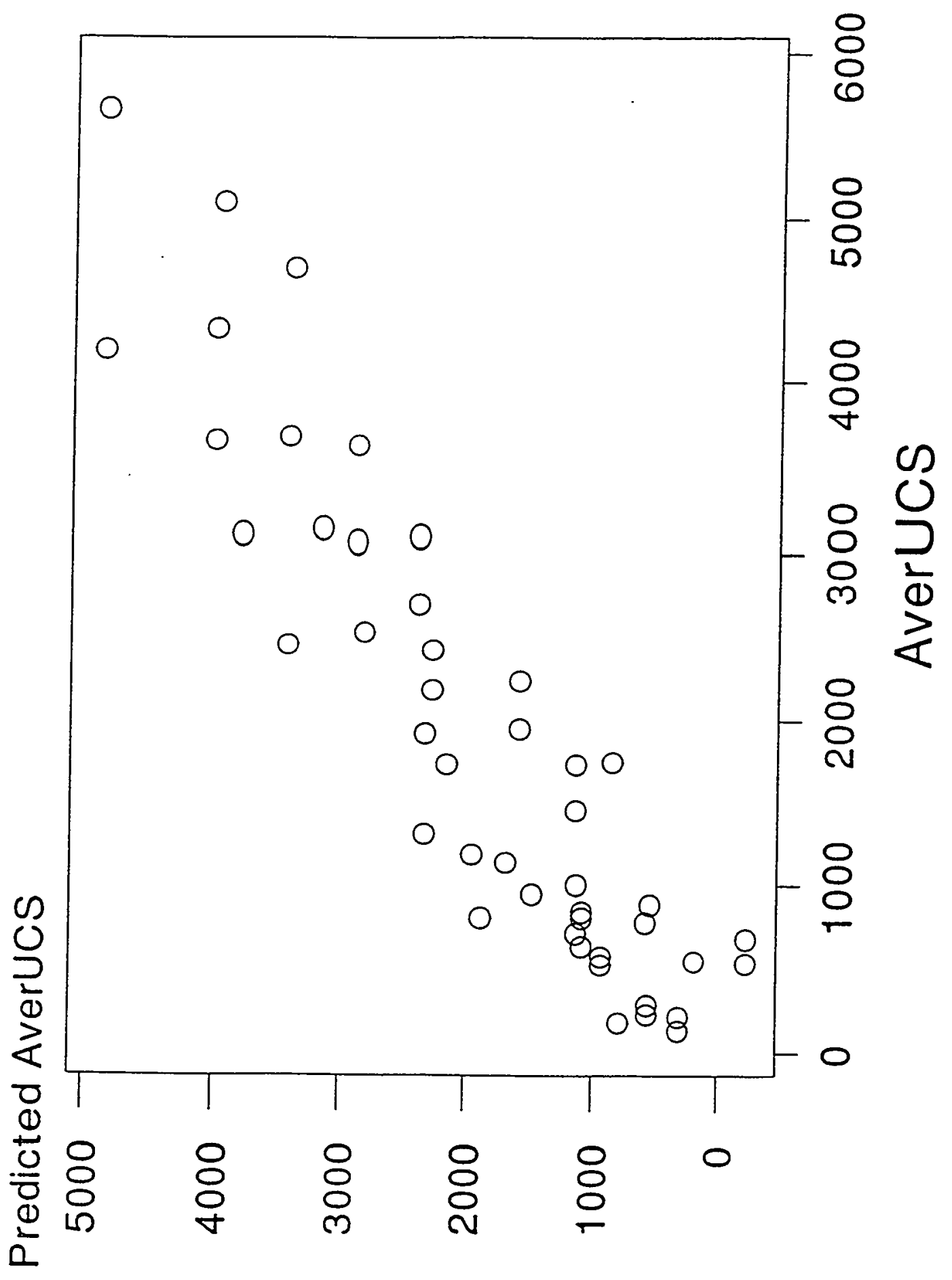




\section{Contour Plot of AverUCS}

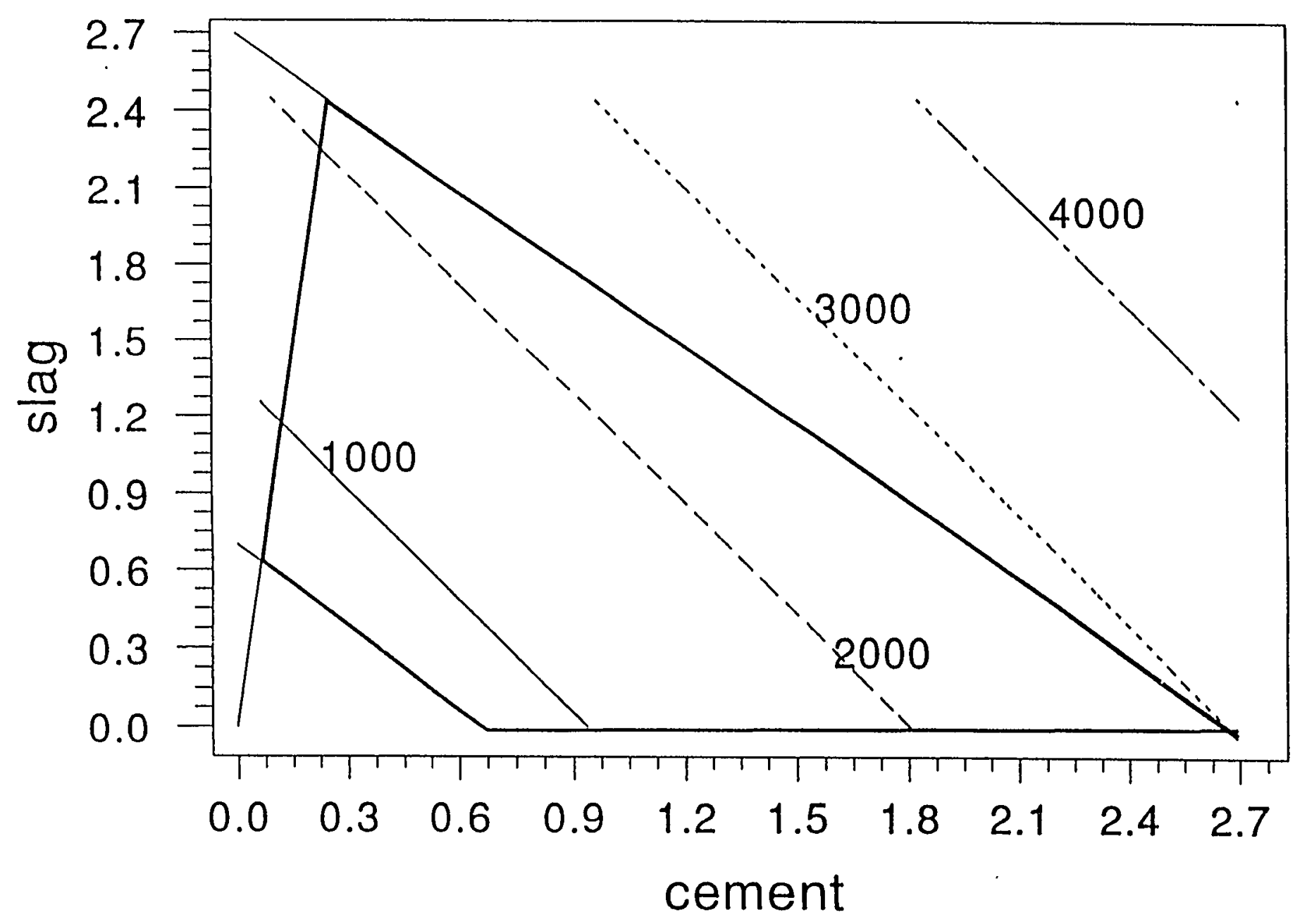




\section{Best Subsets Regression}

Response is InUCS

46 cases used 1 cases contain missing values.

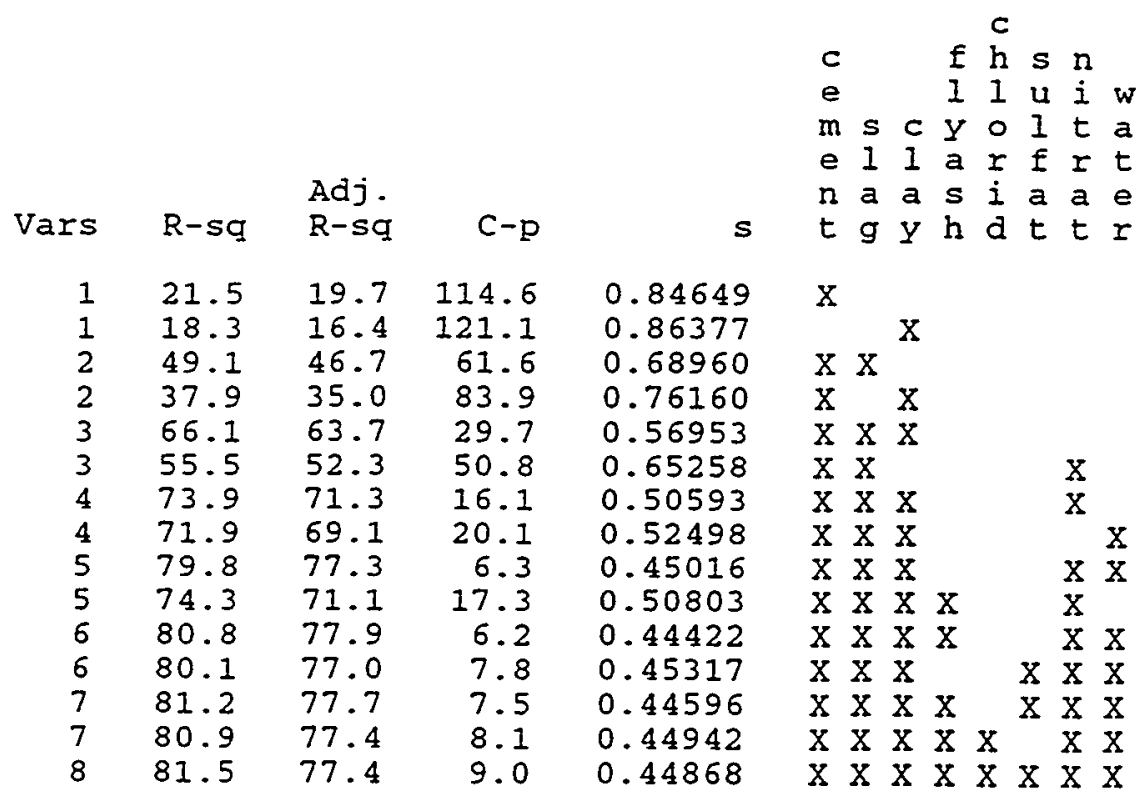


Appendix B

STATISTICAL PRINTOUTS FOR REGRESSION ANALYSIS OF THE PERCENTAGE OF CHROMIUM EXTRACTED DURING TCLP FROM THE INITIAL DESIGN 


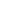


Response Surface Regression

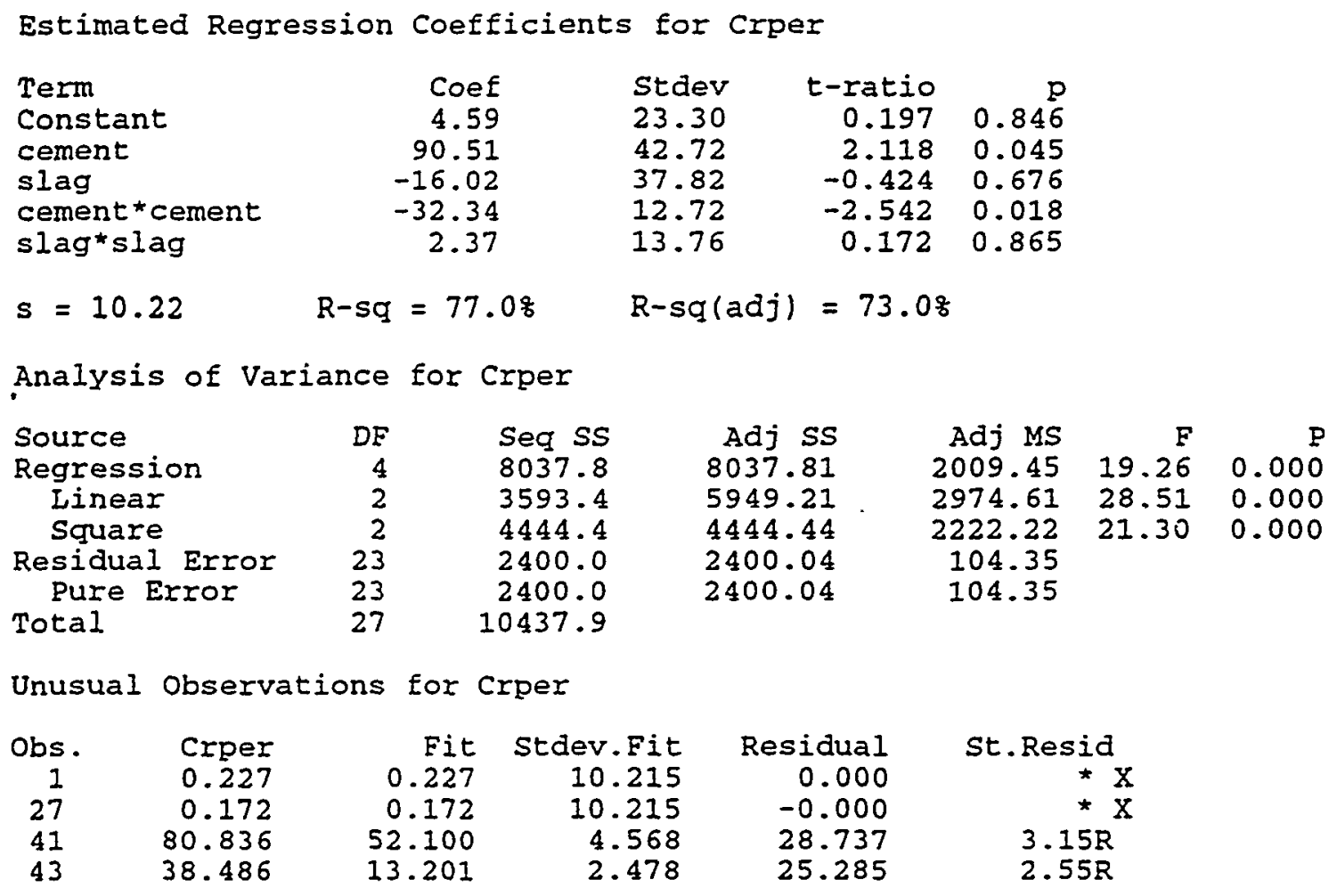


Contour plot for Crper

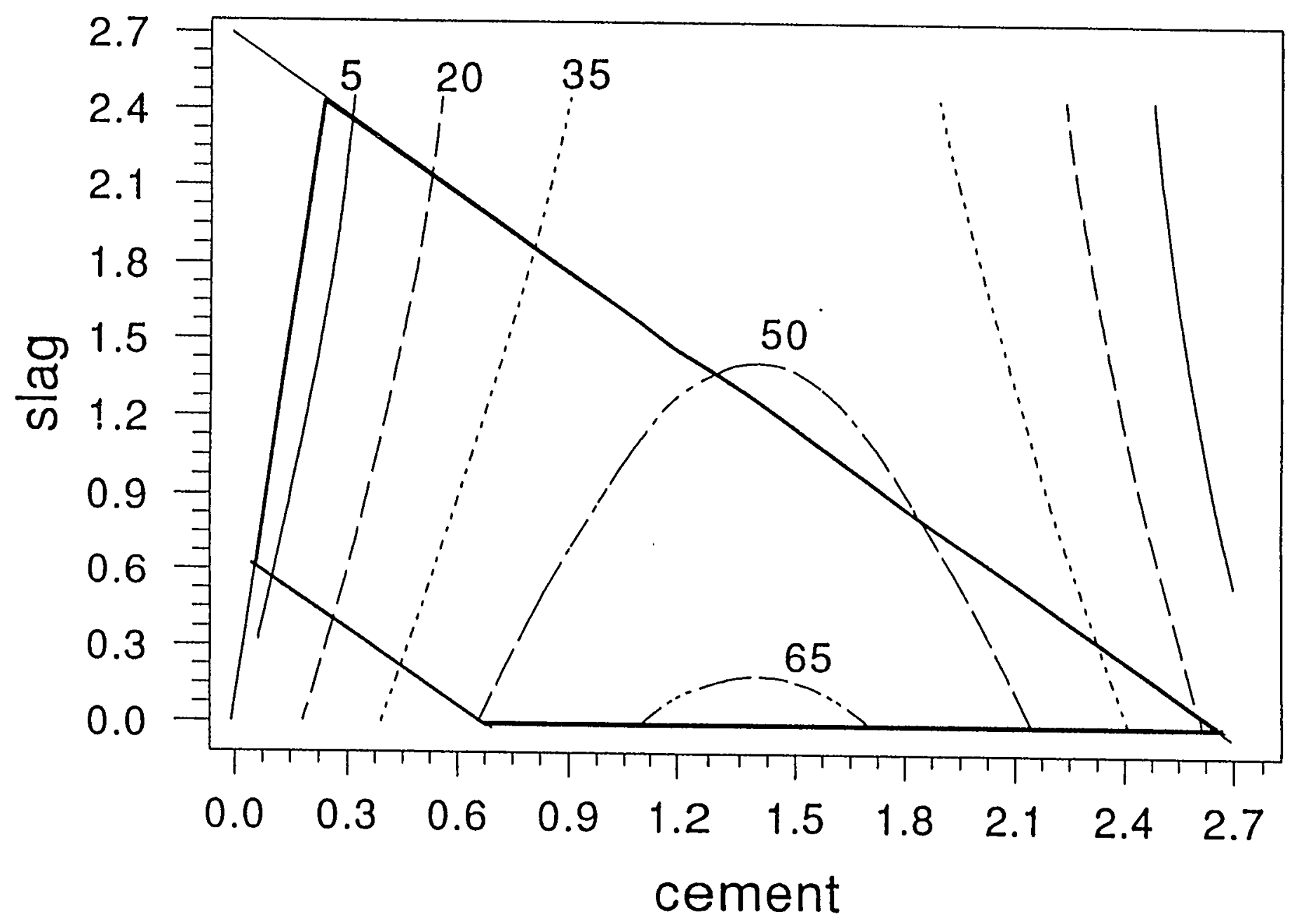


Appendix C

STATISTICAL PRINTOUTS FOR REGRESSION ANALYSIS OF THE UNCONFINED COMPRESSIVE STRENGTHS FROM THE SEQUENTIAL DESIGN DELETING THE ZERO STRENGTHS 


\section{Best Subsets Regression}

Response is Averoucs

16 cases used 16 cases contain missing values.

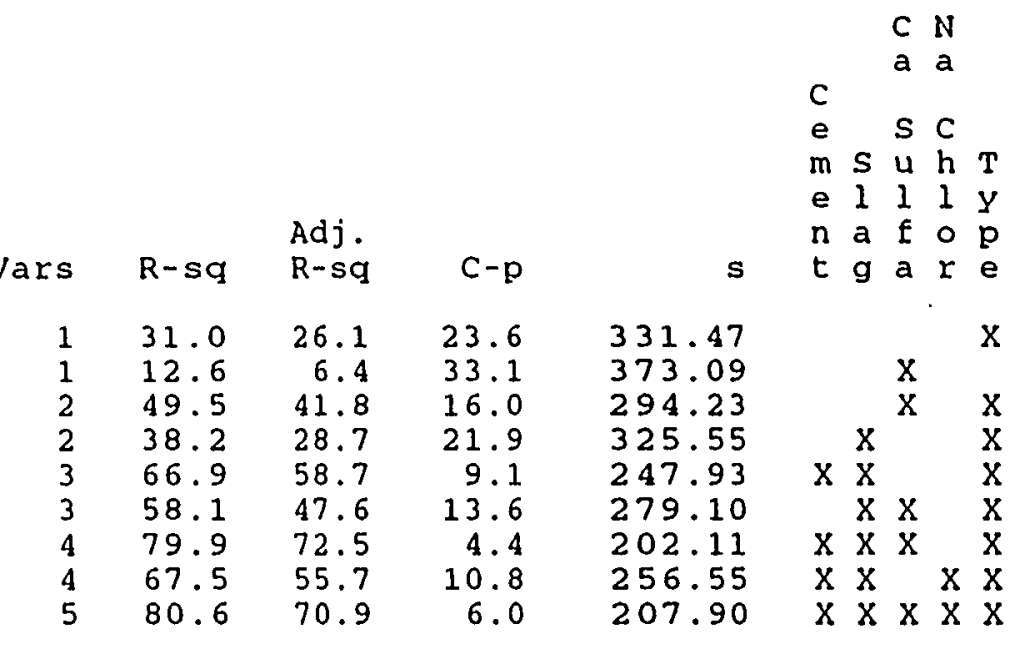




\section{Response Surface Regression}

Estimated Regression Coefficients for Averoucs

$\begin{array}{lrrrr}\text { Term } & \text { Coef } & \text { Stdev } & \text { t-ratio } & \text { p } \\ \text { Constant } & -117 & 382.4 & -0.306 & 0.766 \\ \text { Cement } & 2196 & 735.5 & 2.986 & 0.014 \\ \text { Slag } & 2228 & 608.1 & 3.663 & 0.004 \\ \text { Ca Sulfa } & -2439 & 1197.1 & -2.037 & 0.069 \\ \text { Na Nitra } & 350 & 556.6 & 0.629 & 0.544 \\ \text { Type } & -620 & 123.0 & -5.042 & 0.000 \\ \text { S }=207.9 & \text { R-sq }=80.68 & \text { R-sq(adj) }=70.98\end{array}$

Analysis of Variance for Averoucs

\begin{tabular}{|c|c|c|c|c|c|c|}
\hline Source & $\mathrm{DF}$ & Seq ss & $\operatorname{Adj} \mathrm{SS}$ & Adj MS & $F$ & $\mathrm{q}$ \\
\hline Regression & $\begin{array}{l}5 \\
5\end{array}$ & 1797784 & $\begin{array}{l}1797784 \\
1797784\end{array}$ & $\begin{array}{l}359557 \\
359557\end{array}$ & 8.32 & 0.002 \\
\hline $\begin{array}{l}\text { Residual Error } \\
\text { Total }\end{array}$ & $\begin{array}{l}10 \\
15\end{array}$ & $\begin{array}{r}432239 \\
2230022\end{array}$ & 432239 & 43224 & & \\
\hline
\end{tabular}

Unusual Observations for Averoucs
Obs. Averoucs
stdev.Fit Residual
$-427.472$
St.Resid
16
666.055
94.653
$-2.31 R$ 


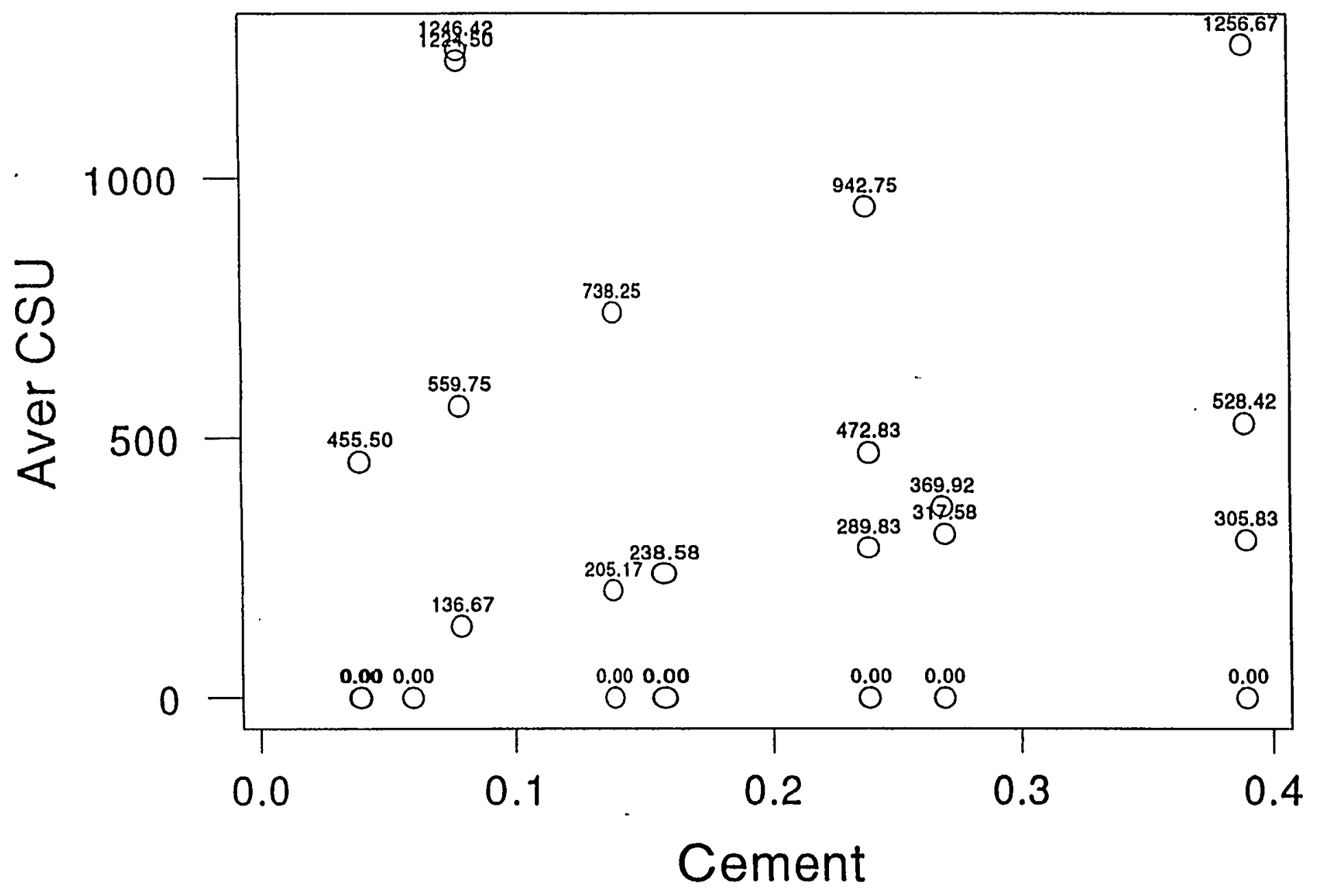




\section{Best Subsets Regression}

\section{Response is Lnoucs}

16 cases used 16 cases contain missing values.

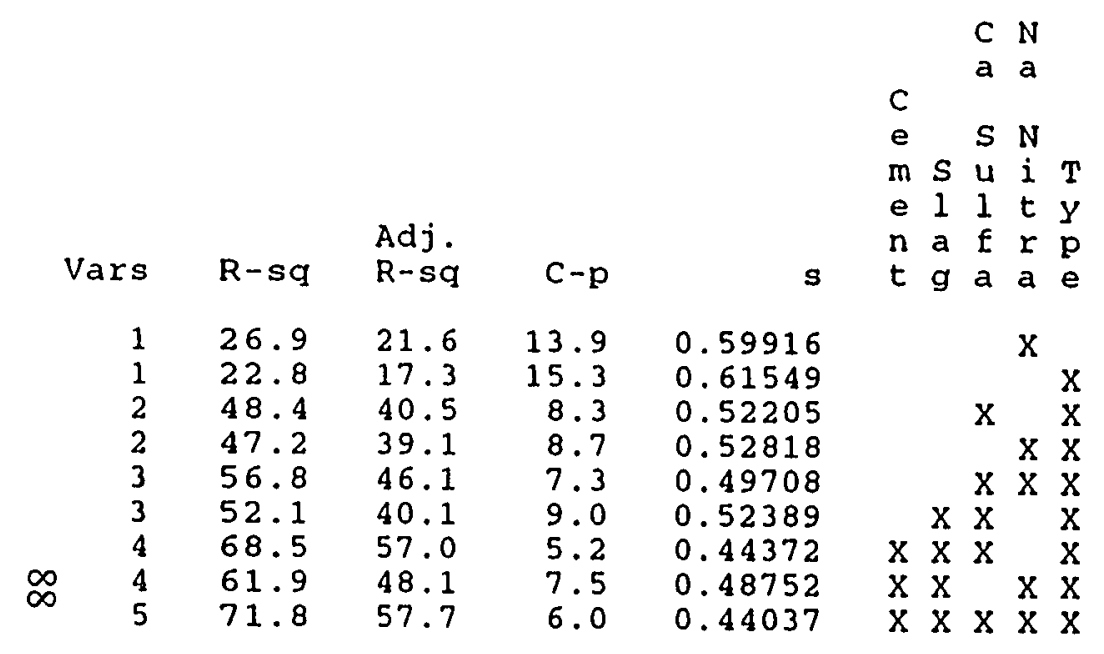




\section{Response Surface Regression}

Estimated Regression Coefficients for Lnoucs

$\begin{array}{lrrrr}\text { Term } & \text { Coef } & \text { Stdev } & \text { t-ratio } & p \\ \text { Constant } & 4.898 & 0.8100 & 6.047 & 0.000 \\ \text { Cement } & 3.041 & 1.5579 & 1.952 & 0.079 \\ \text { Slag } & 2.902 & 1.2881 & 2.253 & 0.048 \\ \text { Na Nitra } & 1.274 & 1.1789 & 1.081 & 0.305 \\ \text { Ca Sulfa } & -4.731 & 2.5356 & -1.866 & 0.092 \\ \text { Type } & -0.918 & 0.2605 & -3.523 & 0.006 \\ \text { s }=0.4404 & \text { R-sq }=71.88 & \text { R-sq(adj) }=57.78\end{array}$

Analysis of Variance for Lnoucs

$\begin{array}{lrrrrrr}\text { Source } & \text { DF } & \text { Seq SS } & \text { Adj SS } & \text { Adj MS } & \text { F } & \text { P } \\ \text { Regression } & 5 & 4.93147 & 4.93147 & 0.986293 & 5.09 & 0.014 \\ \quad \text { Linear } & 5 & 4.93147 & 4.93147 & 0.986293 & 5.09 & 0.014 \\ \text { Residual Error } & 10 & 1.93928 & 1.93928 & 0.193928 & & \\ \text { Total } & 15 & 6.87074 & & & \end{array}$

Unusual Observations for Lnoucs
Obs. Lnoucs
Fit
Stdev.Fit
Residual
St. Resid
$16 \quad 5.475$
6.281
0.200
$-0.807$
$-2.06 \mathrm{R}$ 



\section{ORNL/TM-13725}

\section{INTERNAL DISTRIBUTION}

1. M. W. Burgess

2. T. B. Conley

3. D. G. Cope

4. G. B. Ganapathi

5. R. T. Jubin

6. C. M. Kendrick

7. T. E. Kent

8. B. E. Lewis

9. A. J. Mattus

10. C. H. Mattus

11. C. P. McGinnis

12. T. E. Myrick

13. T. H. Monk
14. S. M. Robinson

15. M. K. Savage

16. C. B. Scott

17-28. R. D. Spence

29. J. R. Trabalka

30. J.R. Travis

31. S. D. VanHoesen

32. T. M. Welch

33. Central Research Library

34. Laboratory Records - RC

35-36. Laboratory Records - for submission to OSTI

\section{EXTERNAL DISTRIBUTION}

37. Mary K. Andrews, Westinghouse Savannah River Company, P.O. Box 616, Bldg. 773-A/B-120, Aiken, South Carolina 29808

38. Darryl D. Downing, Smithkline Beecham, 709 Swedeland Road, MS-UW281A, King of Prussia, Pennsylvania 19406

39. Valerii V. Fedorov, Smithkline Beecham, 709 Swedeland Road, Bldg. 28A, MS-UW280C, King of Prussia, Pennsylvania 19406

40. John Harbour, Westinghouse Savannah River Company, P.O. Box 616, Bldg. 773-A/B-120, Aiken, South Carolina 29808

41. Langdon Holton, Pacific Northwest National Laboratory, P.O. Box 999, MS AO-21, Richland, Washington 99352

42. William Holtzscheiter, Westinghouse Savannah River Company, P.O. Box 616, Bldg. 773-A-232, Aiken, South Carolina 29808

43. David A. Hutchins, U.S. Department of Energy, 55 Jefferson, MS-EW92, Oak Ridge, Tennessee 37830

44. Paula Kirk, U.S. Department of Energy, 55 Jefferson, MS-EW92, Oak Ridge, Tennessee 37830

45. Vince Maio, Idaho National Engineering \& Environmental Laboratory, 2525 N. Freemont, MS- 3875, Idaho Falls, Idaho 83415

46. Cavanaugh Mims, U.S. Department of Energy, 55 Jefferson, MS-EW92, Oak Ridge, Tennessee 37830

47. Johnny O. Moore, U.S. Department of Energy, 55 Jefferson, MS-EW92, Oak Ridge, Tennessee 37830

48. Jacquie Noble-Dial, U.S. Department of Energy, 55 Jefferson, MS-EW92, Oak Ridge, Tennessee 37830

49. Gary L. Riner, U.S. Department of Energy, 55 Jefferson, MS-EW92, Oak Ridge, Tennessee 37830 